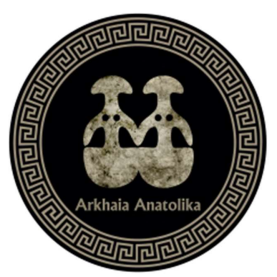

\author{
Arkhaia Anatolika \\ Anadolu Arkeolojisi Araştırmaları Dergisi
}

The Journal of Anatolian Archaeological Studies

Volume 4 (2021)

\title{
Modern Dünya Sistemi, Emperyalizm ve Mesafe-Değişim Oranı Teorilerinin Uyarlama Örnekleri Işığında Yeni Bir Öneri: Tabal-Yeni Asur İlişkisi
}

\author{
A New Proposal in the Light of Adaptation Examples of the Modern \\ World System, Imperialism, and Distance-Parity Theories: The Tabal- \\ Neo-Assyrian Relation
}

\section{Zafer KORKMAZ}

(iDhttps://orcid.org/0000-0002-6018-9533

Geliş Tarihi: 21.04.2021| Kabul Tarihi: 08.07.2021 | Online Yayın Tarihi: 27.07.2021

Makale Künyesi: Korkmaz, Z. (2021). Modern Dünya Sistemi, Emperyalizm ve Mesafe-Değişim Oranı Teorilerinin Uyarlama Örnekleri Işı̆̆ında Yeni Bir Öneri: Tabal-Yeni Asur İlişkisi. Arkhaia Anatolika, 4, 269-313. https:// doi.org/10.32949/Arkhaia.2021.36
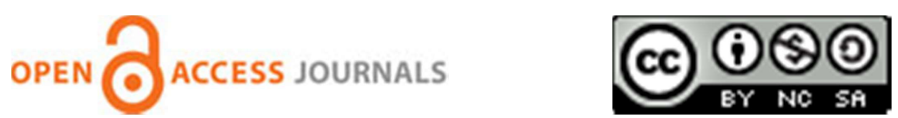

Arkhaia Anatolika, Anadolu Arkeolojisi Araştırmaları Dergisi “Açık Erişimli" (Open Access) bir dergidir. Kullanıcılar, dergide yayınlanan makalelerin tamamını tam metin olarak okuyabilir, indirebilir, makalelerin çıktısını alabilir ve kaynak göstermek suretiyle bilimsel çalışmalarında bu makalelerden faydalanabilir. Bunun için yayıncıdan ve yazar(lar)dan izin almasına gerek yoktur.

Dergide yayınlanan makalelerin bilimsel ve hukuki sorumluluğu tamamen yazar(lar)ına aittir.

Arkhaia Anatolika, The Journal of Anatolian Archaeological Studies follows Open Access as a publishing model. This model provides immediate, worldwide, barrier-free access to the full text of research articles without requiring a subscription to the articles published in this journal. Published material is freely available to all interested online readers.

The scientific and legal propriety of the articles published in the journal belongs exclusively to the author(s). 


\title{
Modern Dünya Sistemi, Emperyalizm ve Mesafe-Değişim Oranı Teorilerinin Uyarlama Örnekleri Işı̆̆ında Yeni Bir Öneri: Tabal-Yeni Asur İlişkisi
}

\section{A New Proposal in the Light of Adaptation Examples of the Modern World System, Imperialism, and Distance-Parity Theories: The Tabal-Neo-Assyrian Relation}

\section{Zafer KORKMAZ*}

\begin{abstract}
Öz
Yazıda, Erken Demir Çağı'nda ve devamında Orta Demir Çağı ile birlikte tarih sahnesine çıan TabalYeni Asur İmparatorluğu ilişkileri Modern Dünya Sistemi, Emperyalizm, Mesafe-Değişim Oranı ve Ticaret Diasporası teorilerinin düşünce kalıplarına uyarlanarak değerlendirilmiştir. Ayrıca, teorilerin düşünce kalıplarının daha önceki uyarlama örneklerine yer verilmiştir. Erken Demir Çağı'na ait Orta Anadolu'da tespit edilen bulgular üzerinden, devlet yapılanmasının nitelikleri üzerine sağlıklı değerlendirme yapmak mümkün değildir. Buna karşın, Geç Hitit coğrafyasında arkeolojik bulgular ve kısmen yazılı belgeler devlet yapılanmasına dair bir takım düşüncelerin oluşmasına yardımcı olmaktadır. Bu bulgulara göre Güney Anadolu' da "taşra ya da perifer modeli imparatorluk" yönetimi uygulanmıştır. Yeni Asur Krallığı'nın MÖ 9. yüzyılın ortalarından MÖ 8. yüzyılın ortalarına kadar olan sürede Tabal Ülkesi'ne yaklaşımı, modern dünya sistemi teorisine göre eşitsiz değişime dayalı, periferine hâkim olan çekirdek devlet tanımı ile uyumludur. MÖ 8. yüzyılın ikinci yarısında ortaya çıan Asur-Urartu rekabeti sebebi ile Asur, Tabal Ülkesi'nin yönetiminde gayriresmi imparatorluk sistemine geçtiğini göstermektedir. II. Sargon Dönemi'nde daha önceki Tabal krallarına yapılmayan bir muamele yapılarak, Tabal kralının oğlu Ambaris, Asur sarayına damat olmuştur. Ayrıca aynı kral döneminde çeyiz yolu ile ülkenin toprakları genişletilmiştir. Ancak tüm bu el üstünde tutmaya rağmen, MÖ 8. yüzyılın sonlarına doğru Tabal Ülkesi Yeni Asur Krallığı'nın eyaleti olur. Tabal Ülkesi'nin eyalet olmasına kadar geçen sürede sorunların çözümü için Yeni Asur Krallığı, askeri faaliyetlerin yanında seçeneklerin tümünü uygulamıştır. Bu uygulamalar, mesafe-değişim oranı teorisine göre Yeni Asur Krallı̆̆ı'nın diplomasinin tüm seçeneklerini kullandığını ve maliyet unsurundan kaçındığını göstermektedir.
\end{abstract}

Anahtar Kelimeler: Tabal, Yeni Asur, modern dünya sistemi, mesafe-değişim oranı, gayriresmi imparatorluk, ticaret diasporası, teorik arkeoloji

In this paper, Tabal-New Assyrian Empire relations, which emerged on the stage of history with the Early Iron Age and the Middle Iron Age, were evaluated by adapting them to the thought patterns of the Modern World System, Imperialism, Distance-Parity and Trade Diaspora theories. In the article, previous adaptation examples of the thought patterns of the theories are given. It is not possible to make a sound evaluation on the characteristics of the state structure based on the findings found in Central Anatolia belonging to the Early Iron Age. On the other hand, archaeological findings and partially written documents in the Late Hittite geography help to form some ideas about state structure. According to these findings, the "provincial or peripheral model empire" administration was applied in southern Anatolia. The approach of the Neo-Assyrian Kingdom on the Land of Tabal from the middle of the 9th century BC to the middle of the 8th century BC is compatible with the definition of a core state that dominates its periphery, based on unequal change, according to the modern world system theory. Due to the Assyrian-Urartian rivalry that emerged in the second half of the 8th century BC, Assyria shows that the Tabal Country has passed into the unofficial imperial system. During the Sargon II Period,

* Dr. Öğr. Üyesi Zafer Korkmaz, Selçuk Üniversitesi, Edebiyat Fakültesi, Arkeoloji Bölümü, Konya/TR. E-mail: zaferkorkmaz@selcuk.edu.tr / Orcid iD: 0000-0002-6018-9533

Söz konusu çalışma, Selçuk Üniversitesi, Bilimsel Araştırma Projeleri biriminin 14401073 proje numaralı “Doğu Kapadokya Demir Çağları ve Hellenistik Dönem Arkeolojik Araştırmaları" konusu ile ilgili olup, ilgili birimce desteklenmiştir. 
the Tabal king's son Ambaris became a groom to the Assyrian palace, a treatment that was not done to the previous Tabal kings. In addition, during the same king period, its lands were expanded by dowry. However, despite all this esteem, Tabal became a province of the Neo-Assyrian Kingdom towards the end of the 8th century BC. In order to solve the problems until the Tabal Country became a state, the New Assyrian Kingdom applied all options besides military activities. These applications show that according to the distance-rate of change theory, the Neo-Assyrian Kingdom used all the options of diplomacy and avoided the cost factor.

Keywords: Tabal, Neo-Assyrian, modern world system, distance-parity model, informal empire, trade diaspora, theoretical archeology

\section{Giriş}

Modern Dünya Sistemi, Emperyalizm, Mesafe-Değişim Oranı ve Ticaret Diasporası teorilerinin tümü Dünya'nın farklı coğrafyalarındaki farklı modern ve antik kültürler için uyarlanmıştır. Çalışılan konunun veri dağarcığının nitelikleri, uyarlamanın kurgulanmasında ana hat planını meydana getirmiştir. Örneğin, Anadolu'nun Prehistorik Dönemi'ni konu alan teorik uyarlamada, çekirdek ve perifere ait nitelikleri doğrudan yansıtan arkeolojik veri setleri kullanılmıştır. Protohistorik Dönemi konu alan uyarlamada ise arkeolojik ve yazılı belgelerin bir arada kullanıldığı görülür. Bu teoriler, Yakındoğu'nun diğer coğrafyalarında olduğu gibi Anadolu'nun Prehistorik ve Protohistorik dönemlerinin kültürel kimliğinin tanımlanması için oldukça faydalı araçlardır.

Erken Demir Çağı'ndan itibaren Geç Hitit coğrafyasında kurulmuş olan beylik ve krallıkların tümü Yeni Asur kralları ve ordusu ile önce mücadele etmek, sonrasında anlaşmak zorunda kalmış ve nihayetinde Asur Krallığı'nın eyaleti olmaktan kurtulamamışlardır. Bu bağlamda Doğu Akdeniz ve Kuzey Suriye'deki Asur hegemonyasının en batı noktasını Tabal Ülkesi oluşturmaktadır. Bu yazıda, Tabal Ülkesi'nin Asur Ülkesi'ne en uzak bölge olması sebebi ile burada kurulmuş olan Asur hegemonyasının oluşum ve uygulama süreçleri değerlendirilmek istenmiştir. Tabal Ülkesi'nde doğrudan Asur üretimi olarak tanımlanacak çok az sayıda arkeolojik malzeme tespit edilmiştir. Bunun yanında Tabal Ülkesi'nde, Asur sanatı ve kültürüne ait ögeler en çok, diğer Geç Hitit Beyliklerinin yayıldığı coğrafyada da olduğu gibi, heykeltraşlık eserlerinde görülür. Verilerdeki bu hem genel hem de kısıtlı durum, doğrudan Tabal-Yeni Asur ilişkisini açıklayan arkeolojik bir referans kaynağı oluşturmaktan uzaktır. Bu sebeple yazıda, yazılı belgeler üzerinden elde edilen sonuçlardan uyarlama yapılmaya çalışılmıştır. Tabal-Yeni Asur ilişkilerinin anlatıldığı bölümünde ise, idari ve siyasi durum tanıtılarak, Tabal Ülkesi ilgili teorilere uyarlanmıştır.

\section{Teorilerin Ortaya Çıkışı}

Batı dünyasında eski eserlerin arkeoloji disiplini içinde değerlendirilmesi, 18. yüzyılın son 30 yılına kadar uzanır. Bu dönemden Birinci Dünya Savaşı'nın sonuna kadar olan süreçte arkeolojinin değerlendirme metotları, arkeolojik nesne ve olguların değişim ya da gelişim aşamaları genel hatları ile tanımlanmıştır. Birinci Dünya Savaşı'ndan 1970'li yıllara kadar olan süreçte, arkeolojinin konuları arasında iki bilgiye ulaşmak önem kazanmıştır. Bu bilgilerden ilki bir kentin, bölgenin, ülkenin veya halkın diğer yerler ile olan siyasi ve kültürel ilişkileri ile ekonomik etkinliğinin sınırları hakkında bilgi edinmek, sosyal ve ekonomik olguların çıtısını almaktır1. İkinci amaç ise yapılan çalışmalarda daha önceki dönemlerde elde edilmiş bilgilerin arasında kalan bilgi boşluklarının giderilmesi olmuştur. $\mathrm{Bu}$ amaç doğrultusunda, 20. yüzyılın son 40 yılı boyunca ve 21. yüzyılın ilk on yılında, on iki farklı arkeolojik yaklaşım ortaya konulmuştur². Bunlardan Sovyetler Birliği, Batı Avrupa,

1 Morrison 2009, 7-8.

2 McGuire 1992, 5. 
ABD ve ülkemizde, 1930'lu ve 1960'lı yıllardaki siyasi atmosferin de etkisi ile arkeolojik nesne ve olguların değerlendirilmesinde temelini felsefe, sosyoloji, iktisat ve siyaset bilimi gibi alanlardan alan "Marksist arkeoloji"3, "yeni/süreçsel arkeoloji"4 ve ülkemizde de olmak üzere "analitik arkeoloji" 5 teorileri öne sürülmüştür.

Yeni arkeoloji ya da süreçsel arkeoloji teorisinde, kültürün tüm kademeleri ve farklılıkları ile anlaşılması amaçlanmış, kültürü açıklamada arkeolojinin antropolojiyle birlikte çalışması gerekliliği vurgulanmıştır. Teori, materyal kültürünün üç temel işlevsel alt sınıfını tartışırak (teknomik, sosyo-teknik ve ideo-teknik), üretimde ihtiyacın giderilmesinden statü kazanmaya doğru gerçekleşen aşamaları incelemiştir' ${ }^{6}$. 1970'li ve 1980'li yıllarda geliştirilen teoriler, göstergebilim ışığında gelişen post-süreçsel ve bilişsel arkeoloji fikirlerinden referans alarak, değişikliklere uğramıştır7. Bu değişimin 2000'li yıllardan günümüze kadar olan tüm yansımaları I. Hooder tarafından "Dolanıklık Teorisi" olarak adlandırılmaktadır. Teori, buluntu varlığı ve/veya niteliğine bakılmaksızın, bir yönetici kişi ya da grubun düzenlemesinin olup olmadığının bilinmediği veya düzenlemelerin ancak bir bölümünün tespit edilebildiği yerleşim yerlerinin birey merkezli izahını yapmayı amaçlar. Buna karşın yönetici mekanizmanın işlediği, yaşama dair düzenlemelerin bilindiği ve bu düzenlemelerin arkeolojik karşıllklarının tespit edildiği bir yerleşim yerinin veya dönemin izahı için tüm unsurları kapsayacak teoriler öne sürülmüştür. $\mathrm{Bu}$ ihtiyacın karşılanması doğrultusunda sosyoloji ve siyaset bilimi gibi bilim dallarında ortaya atılmış modern, politik ve ekonomik sistemlerin kurgusu ve işleyişini anlamaya yönelik kuramlar arkeolojiye uyarlanmıştır.

Teoriler arasında, I. Wallerstein'ın geliştirdiği modern dünya sistemi ile M. Doyle tarafından ortaya atılan imparatorluk sistemlerinin incelendiği kuramlar, en çok öne çıkanlardır. Bunlardan modern dünya sistemi teorisi Marksist düşünceden etkilenmiştir. Teorinin temelindeki bölgeler veya devletlerarası ilişkilere yaklaşımı; çekirdek "bölge" veya "devlet", perifer "bölge" veya "devlete" hâkimdir. Çekirdek, uzun mesafeli ticareti-değişimi kontrol eder ve bölgeler arasındaki değiş̧imleri de çekirdek politikaları yapılandırır şeklinde özetlenebilecek bir ön kabuller zincirinden oluşur. Burada tanıtmaya çalışacağımız modern dünya sistemi teorisi, Marksist düşünceden etkilenmiş olsa da, yine bu düşünceden çıkmış arkeoloji teorisi ise tamamen farklı bir ortaya çıkış öyküsüne sahip olup, farklı bir gelişim sergilemiştir9. Eski Doğu Bloku ülkeleri dışında 1970'li yılların sonunda gelişen NeoMarksist arkeoloji ise Marksizm'in düşünce sistemine bağlı kalmış ve Batı demokrasilerinin etkisi ile olsa gerek, bireye dair özellikle sosyal ilişkilerin incelenmesi alanında bir takım yeni

\footnotetext{
${ }^{3}$ McGuire 1992.

4 Trigger 2008, 431-435.

5 1960'l y yllarda Türkiye'de de çalışmalar başlar (Dinçol ve Kantman 1968; Dinçol ve Kantman 1969). 2000'li yıllardaki çalışmalar tematik arkeoloji serisi ile sürmektedir (Duru ve Özbaşaran 2014, 124-130; Preucel 2019, 5-6; Özbilen 2020). Metod için bk. Ökse 2019, 82, şek. 1.

${ }^{6}$ Binford 1962, 217-225; Özbilen 2020, 55-56.

7 Hodder 1979; Hodder 1985; Ericson ve Earle 1982; Trigger 2008, 450-459; Hodder 2018.

8 Fikrin temelinde, bireyin diğer birey ile ve bireyin çevresindeki diğer her şey ile kurduğu ilişki sonucu ortaya çıkan, herhangi bir işlem sürecine dayanan veya dayanmayan şeylerden oluşan bütünün, bireyden topluma doğru genişleyecek şekilde yorumlanması isteği bulunmaktadır (Hodder 2015, 154-158, 165-177). Bu teoriye dayalı çalışma biçiminde mekan bütünlüğü ve mekan içinde birey davranışının tespiti amaçlandığı için kazının başlangıcı hariç, açma ya da plankare oluşturma tercih edilmez. Bilgilerin kıymetlendirilmesinde arkeometri yöntemlerinin işin içine daha çok dahil edilmesi gereklidir. Bu konunun diğer görüşler ile karşılaştırmalı irdelemesi hakkında bk. Duru 2017.

9 Marx, zaman aralığı açıkça zikredilmeden, antik ekonomilerin incelenmesine yönelik basit ve yüzeysel fikirler beyan etmiştir (Marx 2011, 182-185). Ayrica bk. Trigger 1984; Sherratt 1990; McGuire 1992; McGuire 1993; Childe 2006; McGuire 2008; Trigger 2008; Renfrew ve Bahn 2017.
} 
yaklaşımlar geliştirmiştir ${ }^{10}$. Ancak yine de fikrin temelinde toplumsal varlık üzerinde durulmuş, yaşam felsefesi ve ideoloji ile ilgili bir takım ön kabuller ile çalışılmıştır11. Ön kabullere dayalı yaklaşımın arkeoloji teorileri içindeki Anadolu'ya yönelik uygulamaları önce Güneydoğu Anadolu ve Doğu Anadolu bölgelerinin Güney Mezopotamya ile kurduğu ilişkinin niteliklerinin anlaşılmasına yönelik gerçekleşir. Söz konusu bölgeler arasındaki ilişkiler kültür tarihçiliğine ve "eserlerin" sanat tarihi yaklaşımı ile değerlendirilmesine alternatif olarak geliştirilen modern dünya sistemi teorisi temelinde anlaşılmak istenmiştir ${ }^{12}$.

\section{Prehistorik Dönem Hakkındaki Teorilerin Uyarlama Örnekleri ve İlgili Tartışmalar}

Modern dünya sistemi teorisi 16. yüzyıldan 20. yüzyıla kadar Batı Avrupalı devletlerin sıklıkla uyguladığı kolonicilik olgusunu bir düşünce sistemine kavuşturmak adına Wallerstein tarafından geliştirilen teoridir. Bu teori, kolonicilik faaliyeti, çekirdekperifer ilişkisi temelinde 16. yüzyıldan günümüze kadar olan sürede Dünya'yı ekonomi ve siyaset perspektifinden incelemektedir ${ }^{13}$. Wallerstein, teorisini İkinci Dünya Savaşı öncesi askeri güce dayalı sömürge imparatorluklarının, kaynak zengini koloniler üzerindeki egemenliğinin mekanizmalarını anlama çabasından yola çıkarak geliştirmiştir. Bu sebeple söz konusu teoride ticaret olgusu, özgür iradeyle hareket edemeyen zayıf nüfusların az ya da çok sömürülmesi olarak anlaşılmıştır.

Modern dünya sistemi analizine göre ekonomi ve siyaset, çekirdek, çevre ve yarı çevre olmak üzere üç kategoriden oluşmaktadır ${ }^{14}$. Bu teoride 16 . yüzyıldan önce kurulan dünya imparatorlukları, eyaletlerden oluşan büyük bir yapı olarak tanımlanmıştır. Bu devletlerin ekonomilerinin de devletin siyaset kurumlarından ayrılmadan sürdürülen bağımlı üretim modeline dayandığını savunur. Bağımlı üretim modelinde, çevreden merkeze doğru düzenli haraç ödenmesi ekonomik sistemin temelini oluşturmakta ve bölgeler arası ticaret toplam ekonominin bir kısmını meydana getirmektedir ${ }^{15}$. Bu sistemdeki mekanizmalar; çevrenin çekirdeğe iş gücü, maden ve tarım ürünlerini yollamasına, çekirdeğin de çevreye işlenmiş ürün göndermesine dayalıdır. Bağımlı üretim sisteminde uzak mesafe ticaretinde farklı çekirdekler ya da tekeller yararına biriken sermayenin eşitsiz dağılımı da görülür. Bu mekanizmalara sahip olan devletler uzun süre ayakta kalmıştır ${ }^{16}$. Bu sistemin en iyi örnekleri arasında; Hitit İmparatorluğu, Yeni Asur İmparatorluğu, Roma İmparatorluğu ve İngiliz İmparatorluğu sayılabilir. Tersine bir durumda yani sermayenin işbölümünde ortak paydalar arasında pay edildiği ekonomiler imparatorluklara göre çok daha kısa ömürlü olmuştur ${ }^{17}$. Bu teoride toplumsal yapıların oluşumu ile ulusal ekonomilerin ilişkisinin bulunduğu ve bu ilişkinin gelişmesi için toplumlararası etkileşimlerin gerekli olduğu tespiti yapılmıştır. Bu durumda modern dünya sistemi teorisinin, toplumlararası etkileşimler ile ulusal ekonominin gelişimi arasındaki ilişkiyi açıklamada yardımcı olduğu görülmektedir.

10 Trigger 1993, 171-175; Trigger 2008, 445-446.

11 Trigger 1993, 176; Özdoğan 2012, 140; Akın 2015, 34.

12 Her ne kadar kültür tarihçiliğinde 1950'lerden sonra arayışlara girilmiş olsa da yerel kültürlerin üzerinde yeterince durulmadığı için yeni fikirlerin kültür tarihçi yaklaşımın içinde gelişmesi mümkün olmadı (Trigger 2008, 310-311).

13 Wallerstein 1974, 7-11; Wallerstein kuramında "Dünya" sözcüğünü sınırları belirli, birbirleri ile politik ve ekonomik ilişkisi olan bölgeleri tanımlamak ve değerlendirmek için kullanmıştır.

14 Wallerstein 2005, 43-52.

15 Wallerstein 1979, 5-7; Modern dünya sistemi analizlerinin arkeolojide kullanımı hakkında bk. Hall et al. 2011, 236-238.

16 Wallerstein 2005, 159-160.

17 Wallerstein 1999, 11-16. 
Teorinin öne sürüldüğü tarihlerde Mezopotamya kültürünün ticari ilişkiler temelinde araştırılması devam etmektedir ${ }^{18}$. Teorinin arkeolojide kullanımı ilk kez J. Schneider tarafından gerçekleştirilmiştir ${ }^{19}$. Daha sonra P. L. Kohl ${ }^{20}$, K. Ekholm ve J. Friedman ${ }^{21}$ gibi araştırmacılar teorinin arkeolojiye uyarlanması yönünde çalışmalar yapmıştır²2. M. J. Allen²3, G. Algaze ${ }^{24}$, P. L. Kohl ${ }^{25}$ ve S. Pollock ${ }^{26}$ ise ticaret, sermaye, devlet ve kültür yayılımının mekanizmalarını, modern dünya sistemi teorisinin çekirdek-perifer ilişkisi perspektifinden izah ederek, Mezopotamya bölgesinin bilimsel tartışma zeminini genişletmişlerdir.

Modern dünya sistemi teorisini temel alarak teori geliştirmiş araştırmacılardan birisi Algaze'dir. Algaze, teorisinde bağımlılık ve emperyalizm kavramları üzerinden Suriye, İran ve Anadolu'daki Uruk yerleşimlerinin niteliğini değerlendirir ${ }^{27}$. Bu yerleşimlerin Uruklu ekonomik, idari ve politik anlayışı yansıttı̆̆ını belirterek, bu olguyu modern dünya sistemi teorisinin kolonizasyon ile bağlantılı olarak öne sürdüğü "gayriresmi imparatorluk" dahilinde yorumlamıştır ${ }^{28}$.

G. Stein, hem Uruk dünya sistemi teorisine hem de akültürasyon kavramına ${ }^{29}$ yönelik eleştirilerde bulunmuştur ${ }^{30}$. Eleştirinin temelinde coğrafi mesafenin etkilerinin modern

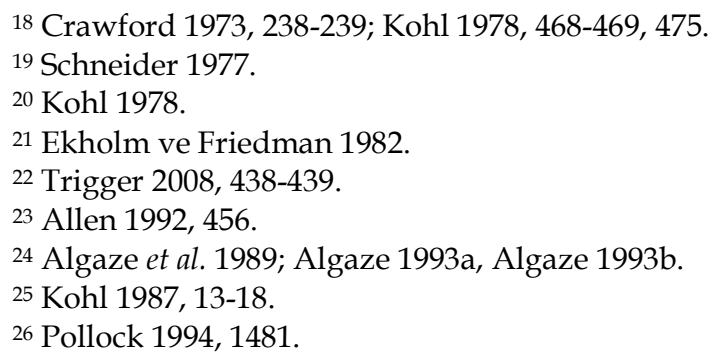
ikincil devletlerin doğuşunu açıklamayı amaçlar. Bu görüşte; Güney Mezopotamya kent devletlerinde (çekirdekte) önce metanın yoğunlaşması hadisesi görülür. Daha sonra, Uruk'un “Suriye, İran ve Anadolu'ya olan ilgisi Güney Mezopotamya'da bulunmayan kereste, değerli taş ve çeşitli madenlerin temin edilmesine yönelir. Bu olguyu üretimde artış takip eder. Uruk ile diğer bölge kent devletlerinin temin talebini karşılamak için kuzeyde bulunan bölgelerde (periferde) Uruk'un bir dizi yerleşim (koloniler) kurması ile süreç devam eder. Kolonilerin kuruluş gayesinin, eski ticaret ağları vasıtasıyla ticari ilişkileri geliştirme amacına yönelik olduğu savunulur. Periferde yerli Kalkolitik Çağ kültürüne sahip toplumlar ile gelişmiş ve örgütlü Uruk kültürü temsilcilerinin buluşması sonucunda kültürler arasında denk olmayan bir yapının ortaya çıktığı savunulur. Bu durumun perifere ait Kalkolitik kültürün Uruk kültürüne karşı bağımlılığa sebep olduğu bildirilir. Çekirdeğe karşı bağımlılı̆̆ın, periferin ekonomisinin çekirdeğin talebi doğrultusunda şekillendiğini ortaya koyar. Algaze, çekirdek içinde bulunan birbirlerine rakip kentlerin ticari nüfuz alanlarını genişletme istekleri olduğunu öne sürer (Algaze et al. 1989, 590). Rekabete dayalı olan nüfuz alanı denetiminin çekirdek-perifer karşıtlığı ve asimetrik ekonomik ilişkiler üzerinden yürütüldüğü kabul edilmiş ve bu doğrultuda çevre ile periferin homojen yapılar olarak görülmemeleri gerektiği söylenerek, kurama yönelik redüksiyonizm eleştirisi savuşturulmuştur (Algaze 1993a, 25-29, 70-90; Algaze 1993b, 306-309; Algaze 2001, 199). Uruk periferindeki yerel güçler, statülerini korumak adına Güney Mezopotamya ile olan ticari ilişkilere bel bağlamışlardır (Allen 1997, 102-103; Helms 1992, 159-164; McMahon 2020, 293). Kuzeyin bağımlılı̆̆ına ve emeğe dayalı yoğun üretimine karşılık, çekirdeğin perifere tekstil gibi mamul mal göndermesinin, ekonomide çekirdeğin merkezi kontrolünü güçlendirdiği ve periferdeki ekonomik çeşitliliği baltaladığı ve bu sebeple de Uruk tahakkümünün emperyal olmaktan ziyade ekonomik olduğu belirtilir. Sonuçta, bu yerleşim yerlerinin Uruk dünya sisteminin ve Uruk emperyalizminin bir parçası haline geldiği ve bu yerleşimlerden de yakınlarında bulunan diğer yerleşimlere kültürün taşınmasının gerçekleştiği savunulmuştur. Geç Kalkolitik Çağ kuzey yerleşimlerinin üretim artışının, sosyoekonomik gelişmeyi beraberinde getirdiği belirtilir. Yerel güçler Uruk'tan öğrendikleri yönetim metotları ile mal değiştokuşu üzerinde daha fazla kontrol uygulamaya başlar. Algaze, bu noktadan sonra lüks tüketime olan talebin artışı ile birlikte güneye kaynak akışını kesintiye uğratarak, Geç Uruk Dönemi'nin çöktüğünü ortaya koyar. 28 Algaze et al. 1989, 572.

29 Akültürasyon kavramına dair yapılan ilk çalışmalarda "geleneksel" ya da "alıcı kültürler" olarak tanımlanan toplumların "kaynak kültürün" farklı unsurlarını doğrudan benimsemeye yönelik isteği sonucunda gerçekleşen olguların bütününü anlamak amaçlanır (Barnett et al. 1954; Cusick 1998, 123-127, 132). Bu bakış açısının temelinde, çekirdekte yer alan kültürü yeniliklerin kaynağı, çevrede yer alan kültürü ise yeniliklerin alıcısı olarak 
devletlerde olduğu gibi kolaylıkla bertaraf edilemeyeceği düşüncesi vardır. Kolonilerin iç bölgelere doğru genişlemesinin Uruk kültürü etkisini azaltacağını öne sürer. Uruk'un tek başına uzun mesafeler üzerinde politik ve ekonomik kontrol sağlamaya gücünün yetmediği ve Uruk kültürel unsurlarının oluşumunda perifere ait unsurların göz ardı edilmemesi gerektiği savunulmuştur ${ }^{31}$. Stein, çevre olarak tanımlanan bölgelerde görülen devlet veya yerel güçlerin etkinliğinin minimize edilerek değerlendirildiğini, bölge içi üretim, alışveriş ve teknik gelişmelerin göz ardı edildiğini belirterek, Mezopotamya'nın çekirdek-perifer ilişkisi temelinde şekillenen görüşlere eleştiri yöneltmiştir ${ }^{32}$. Stein görüşlerini, modern dünya sistemi teorisinin çekirdek ve perifer etkileşimi yaklaşımına daha iyi bir alternatif olarak gördüğü "mesafe-değişim oranı ve ticaret diasporası" teorisine dayandırmıştır ${ }^{33}$.

Hacinebi Höyüğ̈̈'nden elde edilen bilgilerin temel alındığg $1^{34}$ bu teoride, iki kültür arasındaki etkileşimi yansıtan özelliklerin aranması ve etkileşime dair üç unsur bulunması gerektiği öne sürülmüştür ${ }^{35}$. Stein, çekirdeğin kültürel alanda baskın olduğunu varsaymadan ticaret diasporası ${ }^{36}$ ve mesafe-değişim oranı teorisinin, özellikle farklı büyüklükteki beylikler arasında güç ilişkilerinin ve etkileşimin doğasını tanımlamada modern dünya sistemi

görmek vardır (Okun 1989, 42-48). Akültürasyon sonucunda alıcı kültür gruplarının büyük oranda kültür erozyonuna uğradığı düşünülür. Bu bakış açısı Akdeniz dünyasında Hellenleşme ve Romalılaşma ile ilgili çalışmalarda daha belirgin bir şekilde gözlenir. Düşünsel anlamda kabul edilebilir gibi görünen akültürasyon olgusunun arkeolojinin kanıta dayalı uygulamalarında da kontrol edilmesi gereklidir (Bu konuda birçok değişken bulunmaktadır. Bk. Stein 1998, 213-214). Bu noktada karşılaşılan en büyük zorluk "alıcı kültüre" ait öğelerin “donör kültüre" ait öğelerin ne kadarını aldığının tespit edilmesidir.

30 Stein 2002, 905.

31 Stein 1998, 209; Stein 1999b, 172.

32 Stein 2002, 904.

33 Stein 1998, 210; Stein 1999b, 45-64. Stein, yukarıda söz ettiğimiz modern dünya sistemi teorisinin üç ön kabulünün geçerliliğini sorgular ve çekirdeğin hem yerel hem de makro düzeyde ana yapılandırma unsuru olarak görülmesine karşı çıkar. Bu teoriye dayalı geliştirilen teorilerin iç dinamiklerin rolünün en aza indirilmesini eleştirerek, "mesafe-değişim oranı ve ticaret diasporası" teorilerini birleştirerek, bir teori önerisinde bulunur.

34 Stein et al. 1996, 211- 212, 221; Stein 1999a, 162-170; Stein 1999b, 19-20; Schwartz ve Hollander 2008, 3156-3157.

35 Bu unsurlar; özel birtakım faaliyetlerin saptanması, yerelde yürütülen ticaretin kim tarafından yapıldığının saptanması (yerel unsurlar, ticari diaspora veya kolonistler) ve etkileşimin bölgesel seviyede beylikler arası ilişkilere yansıması gerekliliğidir (Stein 1999b, 65 vd.). Bu teoride "mesafe-değişim oranı" bölümünde, çekirdeğin çevre üzerindeki gücünün, doğal kaynakların dağılımı, göreceli nüfus büyüklüğü, teknoloji, sosyopolitik organizasyon, askeri güç ve ulaşım maliyeti faktörlerine bağlı oluştuğu belirtilir (Stein 1999b, 63-64).

36 Stein 1999a, 171. Teorinin ikinci bölümünü oluşturan bu tanıma göre; ticaret diasporası, kültürel olarak farklı, örgütlü ve yerel halktan sosyal ve idari olarak bağımsız, uzmanlaşmış tüccarların meydana getirdiği organizasyondur. Stein tarafından öne sürülen bu teori, modern dünya sistemi teorisinde kullanılan ilişkilerden referans alınarak geliştirilmiştir. Ancak iki teori arasındaki temel fark, modern dünya sistemi teorisinde varsayımlar sabittir. Mesafe-değişim oranı ve ticaret diasporası modelinde ise çeşitli koşullar altında ve özellikle mesafelerin artışına bağlı olarak varsayımlarının değiştiği ve çekirdeğin tesirinin azaldığı kabul edilir (Stein 1999b, fig. 4.1). Devletlerin 16.-19. yüzyıl arasında uzak mesafeli ticareti yürüten kimselere ekonomik ve siyasi emniyeti sağlamada geç kalması, ticaret diasporasının ortaya çıkışına zemin hazırlamıştır. Bir ticaret diasporasının amaçları; aynı milletten olan tüccarların belirli malların uzak yol ticaretinin tüm aşamalarını veya çoğunu kontrol etmek, bu yapıların yerel halk ile ilişkilerini düzenlemek, ekonomik kazanımlarını korumak, kendi siyasi ve adli organizasyonunu oluşturmak ve kültürel kimliklerinin güçlü bir şekilde korunmasını sağlamaktır. Tarıma dayalı emek yoğun üretim yapılan toplumların yerel yönetimi diaspora topluluklarını servet ve güçlerini arttırmak için desteklemişlerdir. Sonuçta ticaret diasporasını desteklemek ve vergilendirmek, yerel yönetimin kendi içindeki güç ilişkilerini dengelemeyi sağlar ve çatışmayı önler. Ayrıca ev sahibi topluluk ile zayıf sosyal iletişimi olan diaspora yerel yönetime bağımlı ve sadık kalır. Ticaret diasporası konusunda yapılan çalışmalar, Çin İmparatorluğu'nun Güneydoğu Asya faaliyetleri ile Batı Avrupa'nın 18. ve 19. yüzyılda Afrika ve Asya'da sergilediği faaliyetleri açılamayı amaçlar (Cohen 1971; Curtin 1984, 1-14). Diasporanın en önemli sorunu, uzun süren ticari faaliyetlerdir. Uzun süreli ticari faaliyet, kültürler arasındaki farklılığı azaltarak, diaspora üyelerinin varlığını gereksiz kılar. Bu durum diaspora üyelerini ticaret için bulundukları yeri terk etmeye, bulundukları yerde etnik topluluk olarak varlıklarını sürdürmeye veya yaşadıkları toplum içinde asimile olmalarina sebep olur. 
teorisinden daha iyi sonuç verdiğini öne sürmüştür. Bu bağlamda Algaze'nin görüşlerine yöneltilen ana eleştiri, "çevre" olarak tanımlanan Kuzey Mezopotamya'nın sosyopolitik gelişmelerine yeterince dikkat edilmemesi ve Uruk genişlemesini sadece güney perspektifinden açıklanmaya çalışması olmuştur. Bölgede Stein ${ }^{37}$ ve diğer araştırmacılar tarafından yürütülen çalışmaların sonuçları ${ }^{38}$ da Uruklu tüccarların bulundukları yerde "yerel" ile iletişim kurduklarını, bunun yanında varlıklarını diaspora olarak sürdürdüklerini göstermesi bakımından önemlidir. Tüm üretim faaliyetine rağmen Güney Mezopotamya'da kurulan sistemin sosyal organizasyon (iş bölümü) ve iletişim ögelerinin düzeyi, Mezopotamya'nın geri kalanı ve Yukarı Furat Havzası'ndan daha ileridedir ${ }^{39}$. Bu sebeple Uruk merkezli olan Mezopotamya çekirdeğinin bir dünya sistemi olmasa bile ciddi bir ticari ve kültürel nüfuz sahası yarattığı açıktır.

\section{Erken Tunç Çağı ve Asur Ticaret Kolonileri Dönemi Hakkındaki Teorilerin Uyarlama Örnekleri ve İlgili Tartışmalar}

Son yıllarda yapılan çalışmaların sonuçlarına göre, Hacınebi ya da Arslantepe gibi Uruk etkisinin görüldüğü yerlerde de yerleşimin terk edilmesi söz konusu değildir. Erken Tunç Çağı'nda Hacınebi Höyük'te Orta Fırat kültürlerinin etkisi daha belirgin görülürken, Arslantepe' de Kura-Aras ve Orta Anadolu etkisi ile pastoral yaşam görülmektedir ${ }^{40}$. MÖ 24. yüzyılda kurulan Akad Devleti'nde bölgeler arasında ticaretin işleyişinde, bölgenin çekirdek ya da perifer olmasının bir önemi olmadan akış devam etmiştir¹. Fakat daha sonraya, Erken

37 Stein 2002, 909; Kalkan 2015, 131-132. Stein'in görüşlerinin eleştirisi için bk. Hall et al. 2011, 243-244. Bu çalışmada, Geç Kalkolitik Çağ ve Erken Tunç Çağı'nda Mezopotamya'da kurulmuş devletlerin "emperyalist" faaliyetlerini modern dünya sistemi teorisinin çekirdek-perifer ilişkisi çerçevesinde izah etmeye çalışılmaktadır (Stein 2008, 26).

38 Frangipane 2001a; Frangipane 2009, 33-34; Kalkan 2015, 110. Nitekim son araştırmalarda Suriye'de bulunan Uruk kolonilerinin, çekirdek Uruk'tan bağımsız olarak gelişen ekonomilere sahip oldukları belirtilmiştir (Akkermans ve Schwartz 2003, 204-208). Yukarı ve Aşağı Fırat Havzası'nda MÖ 3900-3500 yılları arasında Hacınebi (Özbal et al. 1999, 64-65), Değirmentepe (Esin ve Harmankaya 1986, 112; Özbal 1986, 112; Kunç et al. 1983, 133-136; Esin 1986, 144-146), Arslantepe (Frangipane 1985, 215-219; Palmieri ve Sertok 1994, 119 vd.), Norşuntepe (Yalçın et al. 1993, 382-383), Tülintepe (Özbal 1983, 203) ve Tepecik (Özbal 1983, 203) yerleşmelerinde maden işleme ve ticaretinin yapıldığı bilinmektedir. Bu yerleşimlerde aynı zaman dilimine ve öncesine ait seramik ve mühür gibi malzeme de Mezopotamya ilişkilerinin belgeleridir (Hauptmann 1982, 31; Esin 1982, 80; Esin ve Arsebük 1982, 124; Gülçur 2000, 381-382; Kalkan 2015, 124-128; Özbal 2011, 183-189; Tekin 2017, 399-403). Hassek Höyük'te yapılan çalışmaların sonuçlarına göre Hacinebi Höyük'te ve Zeytinlibahçe Höyük'te (Frangipane et al. 2011, 1-2) olduğu gibi aynı yerleşimde farklı yerlerde iki kültürlü yaşam ve yerleşim organizasyonu oluşmuştu. Öte yandan, Uruk bölgeleri ile temas halinde olan bu yerleşim yerleri, yerli Uruk ürünlerini kendi maddi kültür ürünlerine yavaş yavaş entegre etmişlerdir (Helwing 1999, 97-98). Mezopotamya'nın kuzeyini ve kuzey çevresini oluşturan perifer coğrafyasında kurumlaşmış merkezi idare ve sosyal tabakalanmaya dair kanıtlar da bulunmuş olup, bu bölgenin kendi içinde üretim ve ticaret ağının Uruk Dönemi öncesinde de kurulmuş olabileceği belirtilir (Frangipane 2000, 443; Frangipane 2001b, 2-3; Palumbi 2011, 213-214; Parker 2013, 216-217).

39 Algaze et al. 1989, 577-578, 581-582, 586, 588-589; Oates 1993, 416-417; Stein et al. 1996, 238-239; Algaze 2001, 221225; Roaf 2003, 53, 63-65; Frangipane 2009, 36-37; Schwartz ve Hollander 2016, 895-897; McMahon 2020, $291-292$.

40 Pearce 2000, 121-122; Frangipane 1998, 294-297; Frangipane 2001b, 6-9; Frangipane 2012, 244-251; Palumbi 2012, $265,268,275$.

41 Edens 1992, 132-134. Akad sonrasında da III. Ur Dönemi'nde devlet bürokrasisi gerek çekirdek gerekse periferde ekonomik hayatın her alanına müdahildir (Steinkeller 1991, 16-17, 22-23, 32; Jaworski 2008, 369 vd.; Cripps 2014, 207-208). Bu dönemin ticari sisteminde merkeziyetçi bir devlet anlayışının gereği olarak yönetime yakın zümrenin oldukça rahat hareket ettiği, bunun yanında Akad Devleti'nin yağmacı ve haraç almaya dayalı ekonomi anlayışının uzak mesafe ticaretini olumsuz etkilediği öne sürülmektedir (Glassner 1986, 23; Kıymet 2019, 21-22). Akad Devleti ile Anadolu arasındaki ticaret ile ilişkili olduğu düşünülebilecek metinlerde, yerel yöneticiler tarafından kötü muameleye maruz kalan Mezopotamyalı tüccarların talebi üzerine Akad kralı Sargon'un Orta Anadolu'da Puruşhanda kentine saldırdığı anlatılırken, başka bir metinde, Naramsin'e karşı birleşen 17 Anadolu kralına karşı yapılan savaştan söz edilir (van de Mieroop 2000, 137-138; Kıymet 2019, 8-13). 
Tunç Çağı III. evresine ait Kültepe' de bulunan Post Akad ve III. Ur mühürleri" ${ }^{42}$, seramik ${ }^{43}$ ve metal buluntular ${ }^{44}$, Mezopotamya-Anadolu arasında yürütülen ticaretin sonraki döneme ait kanıtları olarak yorumlanabilir ${ }^{45}$. Aynı zamanda Erken Tunç Çağı III. evresi ile II. evresinin başlangıcına ait arkeolojik belgeler, zenginlik ve refahın Orta Anadolu'da yayıldığını ${ }^{46}$ ve bununla birlikte idari yapı ve ilgili kontrol mekanizmalarının oluşturulduğunu göstermiştir ${ }^{47}$. Uzak yol ticareti de MÖ 3. bin yılın ortalarından itibaren ham maddeler, temel gıdalar ile mamül lüks malların taşınmasını da içeren hem devlet görevlileri hem de özel girişimciler tarafından yürütülen bir sisteme evrilmiştir. Tunç Çağı' nda özellikle MÖ 3. bin yılın son yüzyılları boyunca bölgesel güce sahip devletler, zaman zaman ganimet de elde etmek için düzenledikleri saldırılar ile bölgede geçici olarak kontrolü sağlamayı başarır. Ancak kontrol, haraç alma veya sınırlarda kalıcı askeri varlık göstermenin ötesine geçmemiştir.

Bu dönemde Yakın Doğu'da bulunan devletler ile birlikte, yerel güçlerin çekirdekperifer oluşumunda belirleyici olduğu düşünülebilir ${ }^{48}$. Fakat bu dönemde siyasi ve askeri

42 Öztürk 2019, 58-60.

43 K. Emre, Karum IV. ve III. tabakalara ait Kültepe seramiğinde Kuzey Suriye ve Kuzey Mezopotamya'nın kültürel etkilerinin görüldüğünü bildirir (Emre 1963, 91). Aynı döneme ait Doğu Anadolu'da bulunan seramik malzeme Kura-Aras, Suriye ve Kilikya'nın etkilerini yansıtmaktadır (Özgüç 1963, 12; Burney 1958).

44 Anadolu ve Mezopotamya Erken Tunç Çağı III evresi öncesinde de metal üretimi ve ticareti yapan iki bölgedir (Yakar 2002, 15-26; Müller-Karpe 2002b, 138-148; Di Nocera ve Palmieri 2003, 36-39; Yıldırım 2010, 19; Lehner ve Yener 2014, 536; de Jesus ve Dardeniz 2015; Yalçın et al. 2015). Erken Tunç Çağ1 II evresinde Doğu Anadolu ile Kuzey Suriye'nin hem metalürjisi hem de buluntuları benzer niteliklere sahiptir (Efe ve Fidan 2006, 21-25). Arslantepe' nin VIA ve VIB tabakalarında elde edilen bulgular kuyumculuk zanaatine işaret ederken, diğer metal malzeme Transkafkas özelliklerini yansıtır (Di Nocera 2010, 264). Er Hanedan Dönemi'nden III. Ur Dönemi'ne kadar olan süreç içinde Ur ve Tell Brak'tan elde edilen altın buluntuların kökeni olarak Güneydoğu Anadolu gösterilmektedir (Maxwell-Hyslop 1977, 84-85). Resuloğlu kazılarında bulunan saç aplikleri Anadolu-Güney Mezopotamya kültürel ve ticari ilişkisine dair diğer belgelerdir (Yıldırım 2006, 11). Erken Tunç Çă̆ı'nda arsenikli bakırın Doğu Anadolu'dan ve Karadeniz'den (Özbal et al. 2000), kalayın Orta Toroslar kuşağından elde edilmesi (Yener ve Vandiver 1993, 256-257; Yener et al. 2015) ve Doğu Anadolu Bölgesi'nde görülen ormansızlaşma (Whallon ve Kantman 1969, 132-133; Willcox 1974, 130), Anadolu'da metal üretiminin açık kanıtlarıdır. Aynı döneme ait Erciyes Dağı yakınlarındaki metal atölyesi, bu üretimin Orta Anadolu'da da yapıldığını gösterir (Yener et al. 2015). Ayrica Anadolu kuyumculuk ürünlerinin uzunca bir zaman talep gördüğünü, Asur Ticaret Kolonileri Çağı'na ait metinlerden öğreniyoruz (Lehner ve Yener 2014, 547). Dolayısıyla, seramik malzeme üzerinde gözlenen kültürel iletişim, metal malzemede de gözlenmektedir.

45 Ayrıca Lagaş kralı Gudea ile III. Ur Dönemi belgelerinde Hahhum kentinden (Michel 1991, 148; Özgüç 2009, 57; Barjamovic 2011, 216-218; Albayrak 2018, 4-5) altın, tekstil ve zeytinyağı gibi hammadde ve ürünler ile bağlantılı olarak söz edilir. III. Ur Dönemi altın tedariki için bk. Oppenheim 1950, 269. Asur Ticaret Kolonileri Çağı tekstil üretim/tedariki için bk. Veenhof 1972, 129. Asur Ticaret Kolonileri Çağı zeytinyağı üretimi/tedariki için bk. Barjamovic 2011, 105. MÖ 25. yüzyıldan 21. yüzyıla kadar Mezopotamya-Anadolu arasındaki bölgelerde ticari faaliyet yanında kültürel unsurların alışverişi de devam etmiştir (Larsen 1977, 120-121; Efe 2007, 60-61; Öztürk 2019, 59). Söz konusu dönemde, MÖ 2300-1900 yılları arasındaki aksamaya, iklim değişikliğine bağlı oluşan şartlar sebep olmuştur (Massa ve Şahoğlu 2015, 72-74). MÖ 2300'lü yıllardan sonra devletlerin uzak mesafeli ticari ilişkilerin artışı ile ticaretin Yakın Doğu'nun dışına taşmasında etkili olduğunu görmekteyiz (Şahoğlu 2005, 354; Kristiansen 2018, 105).

${ }_{46}$ MÖ 3. bin yılının ortalarında ticaret oldukça geniş perspektifte işlediğinden, dönemin Önasya devletlerinin siyasi sınırlarının ötesine uzanmıştır (Kohl 1978, 463-466, fig. 4).

47 Kulakoğlu ve Öztürk 2015; Özgüç 1963, 2; Özgüç 1986a, 31-34: Kültepe Sarayı bu durumun iyi bir örneğidir. Anadolu geneli için bk. Yilmaz 2019, 204-205.

48 Kohl 1978, 489; Edens 1992, 132-133; Frank 1993, 386; Steinkeller 1991, 30-33; Massa ve Palmisano 2018, 82-83. Her iki dönemde ticaret ağları genişlemeye devam ederken, Eski Babil Dönemi'nde, yarı çevresel "kapitalist" şehir devleti ortaya çıkar (Chase-Dunn ve Hall 2000, 97). Benzeri bir yapılanma Eski Asur' da da görülür (Larsen 1987). Anadolu'da yarı çevresel yapılanma için Hauptmann, Norşuntepe'nin VI., VII. ve VIII. tabakalarını örnek vererek (Hauptmann 1971, 71; Hauptmann 1974, 72), Norşuntepe'nin nahiye merkezi olabileceğini ve burasının yanında Korucutepe, Tepecik ve Tülintepe'nin diğer nahiyeler olduğu ve bir merkez etrafında kümelenme şeklinde görülen bu durumun Anadolu geneline uyarlanabileceğini söyler (Hauptmann 1979, 63). 
bakımdan güçlü olmanın, ticari ve ekonomik faaliyeteleri yönlendirme üzerinde doğrudan tesiri yoktur ${ }^{49}$. Asur örneği, bölgesel genişlemenin en önemli strateji olduğu devlet sistemlerinin arasında, diaspora kümesine sahip "kapitalist" bir şehir devleti olarak, tüm bu kaotik düzen içinde ticaretin ne kadar belirleyici olduğunu göstermiştir50.

Ticaret Kolonileri Dönemi'ne ${ }^{51}$ dair Allen tarafından ortaya atılan dünya sistemleri modellemesi, modern dünya sistemi teorisinin esasların takip eder. Allen, Asurluların "üstünlüğünden" ve Anadolu'da ticari hakimiyet kurdukları görüşünden haraketle, ticaret kolonisi olgusunu daha etkin bir yapılanma olarak görerek, ticaret kolonilerinin varlığını "gayriresmi imparatorluk" (Informal Empire) olarak yorumlamak istemiştir52. Yazılı belgelerden elde edilen veriler Asurluların otonomi sahibi olduklarını gösterse de ${ }^{53}$ Kültepe' de elde edilen arkeolojik bulgular iki toplum arasındaki bir farkı ya da üstünlüğü açıkça yansıtmamaktadır ${ }^{54}$.

Stein ve P. Curtin, Kültepe' de bulunan ticaret kolonisinin niteliğini ticaret diasporası olarak tanımlamıştır ${ }^{55}$. Ne var ki ticaret diasporası fikri modern dünya sistemi teorisinde olduğu gibi belirli şartların gerçekleştiğini varsayarak Orta Çağ sonrası olguları izah etme amaçlı ortaya atılmıştır. Bu varsayımlar sebebi ile çok daha eski bir döneme ait arkeolojik olguyu izah ederken, bazı açmazların içine düşülebilmektedir.

Ticaret diasporası fikrinde görülen varsayımlar; siyasi yapı, ekonomik organizasyon ve sosyal kimlik arasında mutlaka bir bağlantı kurulması gerekliliğidir. Modern dünya sistemi teorisinde görülen varsayımlar; çekirdeğin perifer üzerinde hakimiyet kurması, bu hakimiyete bağlı olarak satın alma gücü yüksek-düşük toplumlar arasında eşitsiz değişim oluşması ve sosyal değişimin ana nedeni olarak bölgeler arası ticaretin görülmesidir. Ticaret diasporası düşüncesinin sacayağından biri olan siyasi yap1 konusundaki ilk değerlendirmeler, Asur İmparatorluğu'nun Anadolu'daki etkinliği yönündedir ${ }^{56}$. Ancak günümüzde bu görüş geçerliliğini yitirmiştir. Asurluların, Anadolu beyleri ve halkı ile olan iletişimleri ticaret yapma, ticari hisse ve kredilendirmeden oluşur ${ }^{57}$.

Asurlu tüccarların yaklaşımı Anadolu'da fevkalade güzel işleyen bir ekonomik organizasyonun kurulmasına yol açmıştır. Bu sistem, Anadolu'da ve Asur'da Asurlu tüccarları zenginleştirmiş ve bu zenginlik vergi yoluyla Anadolu beyliklerine de yansımıştır ${ }^{58}$. Anadolu kentlerinde zaman zaman huzursuzluk çıkmış olsa da Asurlular

49 Frank 1993, 386, 390, 415-416; Veenhof 2010, 40-48. Mezopotamya'da Yeni Asur Devleti'nin kuruluşuna kadar Önasya'nın neredeyse tamamını kontrol eden bir güç ortaya çıkmamıştır. Yeni Asur, Kuzey Levant kıyılarında sona eren birkaç saldırı dışında kara devleti olarak varlığını sürdürmüştür.

50 Frank 1993, 391, 396.

51 Arkeoloji teorileri açısından Anadolu-Mezopotamya ilişkilerinde MÖ 2. bin yıla ait veriler, Asur Ticaret Kolonileri Çağı'nda en yoğun biçimde karşımıza çıkar. MÖ 20. yüzyılın başlarından itibaren Anadolu'da bulunan Eski Asur karum ve wabartumları, sundukları arkeolojik ve yazılı belgelerle ticaret kolonileri hakkında bilgi verirler (Michel 2008, 78-79; Barjamovic 2017; Erol 2019; Barjamovic et al. 2019, fig. 2). Bunlar arasında yer alan Kültepe daha uzun süreli sistemli kazıları sebebi ile diğer yerlerden daha fazla bilgi sunar (Özgüç 1986b; Özgüç 1988; Kulakoğlu 2011). Yazılı belgelerin arkeolojik veriler ile birlikte çalışılması, kolonilerin organizasyonu, Asurluların yerel halk ile iletişimi ve Anadolu ile Mezopotamya'da sosyal, ekonomik ve politik gelişmeleri kavramayı sağlamıştır (Dercksen 1996; Larsen 1976; Veenhof 1972). Asurlu tüccarların yürüttüğü ticaret, en iyi bilinen antik devir ekonomik sistemlerinden birisidir. Bu ticaret, Afganistan'dan Anadolu'ya kadar çeşitli kültürleri ve tahıl ile değerli taşlara kadar çeşitli ürünleri kapsar (Allen 1992, fig. 1; Barjamovic 2018, fig. 2).

52 Allen 1992, 467-471.

53 Özgüç 2005, 18-21.

54 Özgüç 2005, 16; Barjamovic et al. 2012, 68-69; Stratford 2014, 35-38; Michel 2017, 84; Albayrak 2018, 10.

55 Curtin 1984, 3; Stein 2008, 33-35.

56 Polanyi 1957, 19-26; Lewy 1958, 101; Lewy 1964, 189 vd.

57 Allen 1992, 464-465; Özgüç 2005, 17, 27-28; Veenhof 2010, 48.

58 Bayram 1993, 3-13; Özgüç 2005, 15; Veenhof 2010, 48-49, 53. 
Anadolu'yu terk etmeyip, sadece ticarete ara vermişlerdir ${ }^{59}$. Asur Ticaret Kolonileri Çağı' nın doğal afetlerden oluşan olaylar zinciri sonucunda sonra ermesi ve takiben Eski Hitit ve Hitit İmparatorluk dönemlerinde Kültepe' de yerleşim görülmez ${ }^{60}$.

Bu huzursuzluk döneminde dahi Asurluların Anadolu' da sergiledikleri sosyal kimlik yönünden ana veri kaynağı ise yazılı belgelerdir. Bu belgelerden Asurlu tüccarların yerli halk ile ilişki kurduğu öğrenilmektedir, ayrıca Kültepe' de bulunan arkeolojik materyalin çok büyük bir bölümü Anadolu kökenlidir61. Bunlara karşın Stein, Asurlu tüccarların kendi örflerine uygun yaşam tarzı sürdürdüklerini öne sürer ${ }^{62}$ ve önerdiği ticaret diasporası teorisini, arkeolojik belgelerden ziyade yazılı belgelere dayandırır.

Yukarıda arz ettiğimiz gibi, arkeolojik konuların modern dünya sistemi veya ticaret diasporası teorileri kullanılarak yapılan izahında ön kabullere ihtiyaç duyulması, arkeolojinin temel çalışma biçimi olan, önce kültürün maddi ögelerinin tespiti zorunluluğu ile ters düşmektedir. Tüm bu maddi kalıntılar tespit edildikten sonra ancak kültürdeki değişimin nedeni sorusuna cevap bulunabilir63.

\section{Hititler Dönemi Hakkındaki Teorilerin Uyarlama Örnekleri ve İlgili Tartışmalar}

Sosyal bilimlerde merkezi yönetime, bürokrasiye, sömürücü ekonomiye, düzenli orduya, çekirdek ve çevre dinamiklerine sahip, içinde politik, ekonomik ve kültürel çeşitliliği barındıran, coğrafi olarak geniş devletlere imparatorluk adı verilir. Bu tanıma göre siyaset bilimi profesörü Doyle, üç tip imparatorluk modelinin bulunduğunu öne sürer. Bu modeller; merkezci, sistemik ve çevresel imparatorluklardır ${ }^{64}$.

\footnotetext{
59 Kuzuoğlu 2010, 479-485.

60 Kulakoğlu 2014, 86-87.

61 Emre 1963; Özgüç 2005, 16-22. MÖ 3. bin yılın sonlarına ait Amik, Kilikya ve Suriye kökenli seramik Kültepe'de bulunmuştur (Özgüç 1950, 84). Orta Tunç Çağı'nda Kültepe'de bulunan Suriye mataralarının ithal ve taklitleri görülmektedir (Emre 1995, 180). Bu mataralar Güneydoğu Anadolu ve Suriye'de olduğu gibi Kültepe'de de genellikle mezar buluntusu olarak ele geçmiştir. Koloni Çağı seramiğinin genelinde Mezopotamya'nın etkilerine pek rastlanmaz. Kültepe-Asur arası güzergahta yer alan Dicle Vadisi ile Kültepe arasında seramik kültürü yönünden ilişki olmadığı belirtilir (Ezer 2008, 142).

62 Stein 2008, 33-35. Ancak Kültepe'de yapılan zooarkeoloji çalışmasında iki toplum arasında tüketim yönünden fark tespit edilmemiştir (Atıcı 2014, 207).

63 Renfrew ve Bahn 2017, 502-504.

${ }^{64}$ Doyle 1986, 46. Merkezci modelde, servet, güç veya prestij gibi kazançlar peşinde olan yönetici sınıf, sistemin temelini oluşturur. Merkezci yaklaşımda, politik çekirdeğin genişleme isteği sonucu tüm değişimin merkezden perifere doğru yayıldığını düşünür. Bu modele göre şekillenen imparatorlukta, güçlü toplum otorite kullanarak, zayıf toplumun sosyopolitik yapısını değiştirebilir ve bu durum iki toplum arasında asimetrik bir güç ilişkisi olarak değerlendirilir (Doyle 1986, 123-124). Bu sistemin kontrolünde zayıf toplum belirli durumlarda kendi iç işlerini düzenleyebilir, ancak toplumlar arası konularda bağımsızlığı olsa bile, bu bağımsızlığı kullanamaz. Arkeolojide bu görüş, imparatorluk çekirdeğinin kendi maddi kültür tarzını perifere yaydığını varsayar (Sinopoli 1994, 162-164). Sistemik modelde çekirdek, çevreden fazlalık elde etmek için silahlı güç kullanarak, çevredeki ekonomik büyümeyi önlemek veya en aza indirmek için çabalar (Doyle 1986, 27-30; Wallerstein 2011, 349-350). Ne var ki merkezci model gibi, sistemik model de çevreye ait kültürel unsurları ve bu unsurların gelişimini kabul etmekte isteksizdir (Schortman ve Urban 1987, 58-61). Sistemik yaklaşım da birçok arkeolojik alanda benimsenmiştir (Ekholm ve Friedman 1982, 93-94, 101). Taşra ya da perifer modeli imparatorluk yönetiminde yerel nüfus üzerinde etkili, yerel politik ve sosyal politikalarda değişiklikler uygulayabilen eyalet liderleri ile emperyal aktörler arasındaki işbirliğine dayalı kurgulanmış idari sistem esastır. Bu modelde bir imparatorluk aktörüyle işbirliği, eyaletin seçkinlerine kaynaklara ve servete ayrıcalıklı erişimi sağlar (Doyle 1986, 25-26, 229231). Ancak söz konusu işbirliği, yerel halkın bu işbirliği eylemini kabul ettiği ölçüde uygulanabilir bir stratejidir (Areshian 2013, 6-8). Söz konusu modellerin başarısında perifer seçkinlerinin istekli ve yetkin işbirlikçiler olmasının önemi büyüktür. Bu önem sebebi ile yönetim modelleri konusunun odağında, perifer yönetiminin oynadığ1 rol yer alır (Doyle 1986, 22-24, 123-127, 229). Doyle, perifer yönetimleri üzerinden yaptığ1 değerlendirmesinde emperyalizmi; bir toplumun diğerine idari düzenleme dikte ettirebildiği toplumlar arası asimetrik bir ilişki olarak tanımlar. Bu diktenin, emperyal ordu veya emperyal bürokratik mevcudiyet yoluyla
} 
Hitit Devleti'nin yazılı belgeleri65, maddi kültür kalıntıları'66 ve maddi kültür kalıntısı bağlamında seramik buluntuları ${ }^{67}$ kültürel kimliği, etkileşimi, ekonomisi ve çekirdek-perifer değerlendirmesinde bilgi veren bir diğer kaynaktır. Anadolu'da yazılı belgelerin gölgesi altında yürütülen arkeolojik çalışmalarda, bir bölgenin kendi içinde görülen veya bölgeler arasında görülen kültürel ilişkilerin ve bu ilişkilerin maddi kanıtlarının Hitit merkezi idaresinin tasarrufları sonucunda şekillendiği görülmüştür68. A. Matessi, Hitit Dönemi'ne dair yorumlarında, imparatorluğun çekirdek ve perifer oluşumuna dair kanıtların dört kategori altında incelenmesini önerir. Bu kategoriler; temel sosyoekonomik gösterge olarak bölgesel çanak-çömleğin niteliğini incelemek. Bu inceleme üzerinden Hitit çekirdek bölgesinin diğer bölgeler üzerindeki kültürel etkinliğini değerlendirmek. Bölgelerin yerleşim sistemlerini incelemek. Bu yol ile sosyal yapı veya politik yapıdaki değişimleri tespit etmek. Hitit merkezi idari sistemi uygulamalarının ülke içindeki dağılımını anlayabilmek için ise Hitit anıtlarının dağılımını incelemek olarak sıralanır ${ }^{69}$.

Merkeziyetçi görüşlere karşılık olarak yapılan yeni araştırmalarda, Hitit kültürünün imparatorluktaki dağılımında değişim olup olmadığını tespit etmek amaçlanmıştır ${ }^{70}$. Bu

doğrudan denetimle yapılmasına gerek yoktur, ekonomik bağlar veya işbirlikçi perifer seçkinleri, çevre üzerinde dikte sağlanması için yeterlidir (Doyle 1986, 40).

65 Ünal 2005, 96-156; Gerçek 2017, 30-33.

${ }^{66}$ Knappett 2005, 86-90.

67 Bilindiği gibi Hitit seramiği MÖ 17. yüzyılda devletin ortaya çıkışından itibaren Ticaret Kolonileri Çağı'́nın seramik geleneklerini takip eder (Mielke 2017, 125-126). MÖ 16. yüzyılın sonunda ortaya çıkan bezemesiz yalın astarlı mal grubu (monokrom seramik/drab ware) Anadolu'da Hitit İmparatorluğu'nun sonuna kadar görülecek baskın seramik haline gelir (Mielke 2016). Hitit seramiğinde bezemesiz yalın astarlı mal grubunun standartlaşması görülürken, bu grubun Hitit etkisi ile yayılımı konusunda Kilikya Bölgesi örnek olarak sunulabilir. Hititlerin Anadolu'daki etkilerinin artması ile beraber, Kilikya Bölgesi'nde de Geç Tunç Çağı I evresine ait seramik kültürü içinde Orta Anadolu biçimleri karşımıza çıkmaya başlamış ve Hitit İmparatorluğu'nun gücü arttıkça seramik kültüründeki bu değişim daha net biçimde gözlenmiştir (Goldman 1956, 349; Slane 1987, 468-469). Geç Tunç IIA/MCI 3-4 evresinde ise seramikte Hitit unsurları baskın hale gelir (Goldman 1956, 205). Hitit ana yurdu dışında Hitit kaynaklı seramik repertuarının baskın hale gelmesinin sistematik bir ticari sömürü ile idari sistemin yansıması olduğu kabul edilmiştir (Postgate 2007, 149). H. Goldman, D. A. Slane ve J. N. Postgate'in çalışmaları gibi M. H. Gates de Kinet Höyük'ün Hitit hegemeonyası altına girdikten sonra monokrom seramiğin buluntu miktarının arttığını söyler. Bu artışın sebebinin merkezi ve standart seramik üretimi ile Hitit İmparatorluğu'nun daha verimli vergi topladığı ve siyasi çekirdeğin üretici çevreyi ekonomik kazanç amacı ile kullanmış olduğu savunulur (Gates 2001, 138-145). Hitit kültürel ve siyasi yayılmacılığının başka bir örneği de Gordion kazılarında tespit edilir. Burada baskın olarak görülen kap biçimlerinin hepsinin Hattuşa' da bulunan çanak-çömlek ile aynı olduğu, ayrıca üretim süreçlerinin de benzer olduğu tespit edilmiştir (Henrickson 1995, 87-88). İmparatorluk mülkü içinde bulunan seramik malzemenin biçim olarak yaklaşık 450 yıllık zaman zarfında bazı küçük değişiklikler ile sürekli kullanımda kalması, Hitit kültürünün değişiminde siyaseten merkeziyetçi yaklaşımının örneği olarak yorumlanmıştır (Korbel 1985, 118-120; Müller-Karpe 2002a, 257; Schoop 2006, 235-237; Konyar 2006, 340-344; Gunter 2006, 357-361; Postgate 2007, 144; Mielke 2017, 138-139). Doğu Anadolu'da Elazı̆̆ ve Malatya illerinde yapılan çalışmalarda, Hitit tesirinin görüldüğü bildirilmiştir (Whallon 1979, 273; Sevin 1991, 87; Esin 1971, lev. 92-94; Hauptmann 1971, 73-74). Bu bölgede yürütülen çalışmalarda çoğunlukla seramik malzeme üzerinde değerlendirme yapılmış ve bu değerlendirmelerde, bölgenin seramiğinin Korucu Tepe ve Norşun Tepe'nin Hitit Dönemi tabakalarına ait malzeme ile benzerlik gösterdiği bildirilmiştir (Whallon 1979, 34-45). R. Whallon'ın araştırmasına göre Norşun Tepe merkez niteliğinde bir yerleşim yeridir (Whallon 1979, 284). Bu yerlere benzer biçimde Malatya Arslantepe de Hitit merkezi idare uygulamalarının görüldüğü bir kent hüviyetindedir (Manuelli 2013a, 216-221, 389-391, 418423.).

68 Schachner 2009, 25-27; Manuelli 2013a, 412-426.

${ }^{69}$ Matessi 2016, 150-153.

$70 \mathrm{Bu}$ düşünce sistematiği Doyle tarafından ortaya atılan görüşler temelinde şekillenmiştir (Doyle 1986, 123-124). Son yıllarda yapılan çalışmalarda seramik konusunda ifade edilen görüşlerin merkeziyetçi düşünceyle oluşturulduğu, ancak Hitit Devleti' nin iç dinamiklerini kavramak adına eyaletlerin yönetim içindeki rollerinin de hesaba katılması gerektiği savunulmaktadır. 
amaç doğrultusunda monokrom seramiğin bölgesel dağılımında görülen farklar üzerinden bazı yeni değerlendirmeler yapılmıştır ${ }^{71}$.

Glatz, söz konusu veriler ile değerlendirdiği monokrom seramik grubu hakkında "Kuzey-Orta Anadolu üslubu" terimini önermiş ve söz konusu seramiği Hitit İmparatorluğu'nun gölgesinden ayırmayı amaçlamıştır ${ }^{72}$. Ancak, Orta Anadolu ve Kilikya Bölgesi'nde bir paralel yayılım olduğu gerçeği mevcudiyetini korumaktadır ${ }^{73}$.

Hitit yayılımının ve periferinin oluşumunda Ugarit, diğer tüm şehirlere nazaran daha önemlidir. Kentin I. Suppiluliuma tarafından ele geçirilmesinden sonra, Hitit İmparatorluğu'nun Yakın Doğu'nun güçlü devletleri arasına girdiği kabul edilir. Bu "fetihten" aldıkları yüklü haraç sebebi ile ilk başta Hititler karlı çıkmış gibi görünse de Ugarit, siyasi ve ticari alanda etki alanını genişletirken, kentin kültürel anlamda Mısır ile etkileşim içinde olduğu tespit edilmiştir ${ }^{74}$. Ugarit örneği, bir yerin vasal ve perifer niteliğinde olmasının ödediği ağır vergiye ${ }^{75}$ rağmen ekonomik etkinliğinin azalacağı anlamına gelmeyeceğini, aksine zenginleşmesi ve topraklarını genişletmesi için sebep olabileceğini göstermesi bakımından önemlidir ${ }^{76}$. Ugarit, yapılan anlaşmalar vasıtası ile Hitit pazarına daha rahat girmiştir. Doyle'ın tanımlamasına göre Hititler, Orta ve Güney Anadolu'da merkezi imparatorluk niteliğinde iken, bu sınırların dışında izledikleri siyaset, Ugarit örneğinde olduğu gibi perifer imparatorluk niteliğindedir ${ }^{77}$.

\section{Erken Demir Çăğ}

Demir Çağı'nda sosyal ve ekonomik konulara ait bilgiler yazılı kaynaklar kadar arkeolojik bulgulardan da elde edilmektedir. Bununla birlikte Erken Demir Çağı'nda yazılı kaynakların susması, arkeolojik veriler üzerinden bilgi edinmeyi zorunlu kılmaktadır ${ }^{78}$. Bu veriler arasında anıtsal mimari ile bu mimarinin ögeleri ayrı tutulursa, bu dönem Anadolu yerleşimlerinde çoğunlukla dere/sel taşı ve kerpiç kullanılarak oluşturulan mimari, detaylı bilgi sunmaktan uzaktır. Fırat ve Dicle havzalarında Erken Demir Çağı seramiği hakkında

71 Glatz 2009, 129-131. Bu çalışmaların temelini, Boğazköy'de bulunan her çanak-çömlek biçimini, Hitit periferinde bulunan üreticilerin üretmediği tespiti oluşturur (Henrickson 1995, 87; Postgate 2007, 144). Glatz, bu durumu emperyal uygulamaya aykırı bir kanıt olarak yorumlar (Glatz 2009, 130). Glatz başka bir çalışmasında, Gates'in çömlekçi damgalarını merkezi seramik endüstrisinin kanıtı sayan argümanını reddederek, bu damgaların bölgelere göre değişen ve çeşitlilik gösteren seramik üretim biçimlerinin ya da üsluplarının bir derlemesi olduğunu öne sürer (Glatz 2012, 34). Ancak imparatorluk merkezi ile birlikte Kizzuvatna'da görülen Orta Anadolu merkezleri ile paralel biçimde artan çömlekçi işareti uygulamasının sebebine değinmez (Glatz 2012, 13).

72 Glatz 2006, 340; Glatz 2009, 129. Bu grubun Anadolu'da dağılımı için bk. Kozal 2003, 70.

73 Orta Anadaolu Bölgesi'ndeki yayılım için bk. Mielke 2007. Kilikya Bölgesi için bk. Manuelli 2009. Burada konu edilen Gratz'a ait çalışmaların sonuçları, farklı seramik türlerinin değerlendirilmesi ve karşılaştırılması amacı ile yazılmış yayınlar üzerinden yapılan analizlere dayanmaktadır. Bu yayınların bazılarında değerlendirilen malzemenin elde edilen bütün malzemeye oranına daha az önem verilirken, bazılarında daha çok önem verilmiştir. Bu sebeple, nicel yöntem ile varılan sonuçlarda sapma bulunması kaçınılmazdır. Örneğin Beycesultan ile ilgili yapılan çalışmalarda monokrom seramiğin tüme oranı \% 90 olarak verilir (Mellaart ve Murray 1995, 21). Ancak Batı Anadolu'da Hititlerin güçlü bir yönetim dinamiği ile etkili olduğuna dair kanıtlar oldukça azdır (Seheer 2005, 39-40; Glatz 2006, 350; Sagona ve Zimansky 2009, 284-286). Beycesultan' da yapılan çalışmalarda III. ve II. tabakada toplam seramik asamblesi içinde Orta Anadolu kökenli seramik oranı ve diğer buluntuların dağılımı Hitit etkinliğinin en azından İç Batı Anadolu'nun güneyinde oldukça az olduğunu gösterir (Mac Sweeney 2010, 14-18).

${ }^{74}$ Glazt 2013, 30-32, 36-37.

75 Drower 1975, 138; Alp 2002, 91.

76 Heltzer 1977, 207-208.

77 Sir Gavaz 2012, 29.

78 Hitit İmparatorluğu'nun yıkılması ile Orta Asur Dönemi belgelerinin Anadolu ile ilgili bilgilendirmeleri son bulur (Kertai 2008/2009, 38). 
bilgilerin önemli bir bölümü söz konusu bölgedeki barajların havzalarında yapılan arkeolojik faaliyet sonucu elde edilmiştir79. Seramiğin yanı sıra mimari bulgular da referans alınarak, Doğu Anadolu'nun Erken Demir Çağı'nda göçer ya da yarı-göçer yaşam döngüsüne sahip olduğu belirtilmiştir ${ }^{80}$. Buna karşın, Erken Demir Çağı boyunca en azından Arslantepe' de ve havalisinde bulunan yöneticiler, mahallerinde tespit edilen yazıt, rölyef ve sur gibi imarinşaat faaliyeti yolu ile bölgelerinde kalıcı olduklarını göstermek istemişler ve böylece varlıklarını vurgulamışlardır ${ }^{81}$. Bu yöneticilerin kendilerini hanedan ailesi olarak bilinir kılmak istemesi, muhtemelen aile geçmişleri ile ilişkilidir. Kargamış hanedanı Hitit hanedanına mensuptur ${ }^{82}$. Bu durum, Anadolu'da pekiştirilmiş bir merkezi idare gerçeğini ortaya koymuştur.

Arslantepe' de MÖ 12. yüzyıl ve sonrasina ait seramik buluntularda Hitit etkilerinin gözlendiği ve bunun yanında Aşağı Fırat Havzası ve Levant Bölgesi ile ilişkili seramiğin de bulunduğu bildirilmiştir83. Bu bölge için oldukça karakteristik olan yivli seramiğin ise MÖ 8 . yüzyıla kadar kullanımda kalmış olması, en azından seramik kültüründe birlikteliğin oluştuğunu gösterir. Daha güneyde Kilikya Bölgesi'nde Tarsus Gözlükule Höyüğü

79 Burada bulunan yerleşim yerlerinden Zeytinlibahçe Höyük'te bulunan Demir Çağ1 örnekleri, Anadolu genelinde karşılaşılan malzeme ile benzerdir (Frangipane et al. 2011, şek. 5b). Şaraga Höyük'te tespit edilen düz dipli oinochoe, matara ve diğer malzeme, Orta Anadolu örnekleri ile benzerdir (Sertok et al. 2011, şek. 8, 11b). Her iki havzada bulunan yerleşimlerden Salat Tepe (Ökse et al. 2001, 598), Şavi Höyük (Dittmann et al. 2002, 213) ve Mezraa Höyük'te (Yalçıklı ve Tekinalp 2004, 122; Yalçıklı ve Tekinalp 2011, 123) tespit edilen malzeme, Kuzey Suriye'nin pişmiş toprak buluntuları ile aynı nitelikleri paylaşır. Doğu Anadolu'nun Erken Demir Çağı'ndan Orta Demir Çağı' nın başlarına kadar görülen yivli seramik grubuna ait örnekler, Dicle ve Fırat havzalarında; SiirtTürbe Höyük (Sağlamtimur 2013, 140), Lidar Höyük (Bartl 2001, 391), Kavuşan Höyük (Kozbe ve Köroğlu 2011a, 628), Kenan Tepe (Parker et al. 2011, 711-712), Gre Dimse (Karg 2001, 650; Karg 2002, 705) ve Giricano (Schachner 2004, 506) gibi yerleşimler ile söz konusu iki havzadaki diğer yerleşimlerde de bulunmaktadır (Özdoğan 1977, 9; Serdaroğlu 1977, tab. 1-10; Whallon 1979, 275; Duru 1979, 42-43; Esin 1987, 91; Esin et al. 1987; Bilgi 1987; Tekinalp ve Alp 1999, 216-217; Kozbe ve Köroğlu 2011b, şek. 4, 12; Köroğlu 2003, 233-237; Erdem 2012; Sağlamtimur 2013, 140; Biber 2018, fig. 229-231). Bunlardan Kenan Tepe'de de yivli seramiğin yanı sıra “Yerli Demir Çağı" olarak adlandırılan bir seramik grubundan söz edilmiştir (Parker et al. 2004, 556; Parker et al. 2011, 711). Tespit edilen seramik ve seramiğin dağılımına göre Erken Demir Çağı'nda benzer seramik kültürüne rastlanmaktadır (Roaf ve Schachner 2005, fig. 4).

80 Köroğlu 2003, 240; Erdem 2012, 120.

81 Manuelli ve Mori 2016, 216-228, fig. 1; di Filippo ve Mori 2019, 174, 176-177, fig. 2. Yukarı Mezopotamya'nın ve Anadolu'nun Erken Demir Çağı Beylikleri Tunç Çağı'ndan gelen bir geleneği sürdürerek toplumsal hafızayı diri tutmak ve daha önemlisi yaşadıkları çevrede varlıklarını net biçimde ortaya koymak adına kentleri ve kentlerin çevresini büyük inşa projeleri ile değiştirme yoluna gitmişlerdir (Harmanşah 2007, 184).

82 MÖ 13. yüzyılın sonlarında Hitit İmparatorluğu; Hattuşa, Tarhuntaşşa ve Karkamış olarak 3’e taksim edilir. Bu taksimde merkez Hattuşa' dır. Hawkins 1994, 91-93; Bronz tabletten anlaşıldığına göre uygulamada Tarhuntaşşa ile Hattuşa'nın statüsü eşit gibi görünmektedir. Kargamış Krallığı'nda, Hitit hanedanı akrabalık ilişkilerinden kaynaklı Kuzi-Teşup'un "Büyük Kral” ünvanı ile yönetimi görülür. Kargamış ve Arslantepe kraliyet aileleri arasında hanedan akrabalığı önce baba-oğul ve devamında dede-torun ilişkisi üzerinden sürmüştür (Hawkins 1988, 103-104; Sagona ve Zimansky 2009, 303; Bryce 2012, 83). Kargamış'ın Milid Krallığı üzerindeki nufüzunun ve hanedan akrabalığının Erken Demir Çağı içinde devam ettiğini, Malatya, Gürün ve Kötü Kale yazıtları ile İspekçur ve Darende stelleri üzerindeki isimlerden öğreniyoruz (Hawkins 2000, 295-305, 321-322; Bryce 2012, 106107).

83 Manuelli 2013b, 380-381; Manuelli 2016, 31; Manuelli 2019, 163. Arslantepe'de MÖ 10. yüzyıldan sonra hem Orta Fırat Havzası hem de Orta Anadolu ile yakın ilişkili seramik malzeme bulunmuştur (Manuelli 2010, 80). Seramik bulguları üzerinden, Doğu Anadolu'nun Erken Demir Çağı'nın ilk iki yüzyılında, Hitit geleneğinden kopmadan bir kültür bölgesini meydana getirdiği değerlendirmesi yapılabilir. Buluntular arasında görülen Orta Anadolu ve Aşağı Fırat Havzası seramiği, akraba hanedanlar arasındaki Kargamış etkili ticari bir ilişkiye işaret edebilir. Doğu Anadolu'nun batı kesiminin Orta Demir Çağı'nda Değirmen Tepe ve Köşker Baba gibi Karakaya Barajı Havzası içinde kalan yerlerde Kıbrıs kökenli malzeme bulunması da ticari ilişki bağlamında ayrıca anlamlıdır (Manuelli 2013b, 381; Ökse 1988, fig. 594-595, 604-611). Karakaya bölgesi Orta Demir Çağı'nda tek renkli, kaba mallardan oluşan yerel seramiğe sahiptir (Ökse 1988, 19). Bu havzada ithal örnekler üzerinden Orta Anadolu, Urartu ve Geç Asur seramik türlerinin kesiştiği tespit edilmiştir. 
buluntuları içinde Erken Demir Çağı başlarında Hitit etkili seramiğin görülmesi ve bu dönem içinde Erken Demir Çağı'nın sonları ve Orta Demir Çağı' nın başlarında ise Kıbrıs kökenli malzemenin görülmeye başlanması, Geç Hitit Devletlerinin bir etkisi olarak yorumlanmıştır ${ }^{84}$. Erken Demir Çağı'nın sonlarına doğru Anadolu'nun Doğu Akdeniz ve Doğu Anadolu'nun batısında Kıbrıs kökenli seramiğin görülmesi, ticari değişime kanıt olarak Karakaya Barajı Havzası ile beraber düşünülebilir.

Alalakh'da bulunan Kıbrıs seramiğinin kıyı yerleşimlerinde bulunanlara göre oranı oldukça fazladır 85 . Orandaki farka göre kıyı bölgelerindeki yerleşikler ile iç kesimde yaşayan insanlar arasında, göçerler bağlayıcı unsurları olmuş, mesafe ve kültürel boşluğu doldurmuş olabilirler ${ }^{86}$. Böylece Erken Demir Çağı'nda Aşağı Fırat Havzası'ndaki nüfusun üzerinde etkili yerel liderler ile Kargamış Krallığı arasındaki işbirliğine dayalı kurgulanmış sistemin bulunduğunu önermek isteriz. Hali hazırda bu durum Yeni Asur İmparatorluğu'nun yayılmaya başlamasına kadar Geç Hitit Beyliklerinin dağıldığı bölgede sosyopolitik yapıdaki değişiklikler ile karakterize bir geçiş dönemi olarak görülmektedir ${ }^{87}$. Güney Anadolu'da, Geç Helladik IIIA ve IIIB dönemlerine ait seramiğin ithal örnekleri ${ }^{88}$ ardından gelen Geç Helladik IIIC dönemi seramiğinden etkilenmiş yerel malzemenin görülmesi, ticari faaliyete ${ }^{89}$ ve bu bölgelere yerleşmiş Egeli insanların varlığına kanıt ${ }^{90}$ oluşturur ${ }^{91}$.

\section{Orta Demir Çă̆ı ve Tabal}

Orta Anadolu'nun Erken Demir Çağı hakkında yapılan seramik çalışmalarında, Boğazköy'de Erken Demir Çağı'nın erken evresine ait genel buluntu topluluğu içinde, Hitit geleneğini anımsatan seramiğin varlığı ortaya çıkarılmış olup, Erken Demir Çağı'nın orta ve geç evresinde tespit edilen malzeme, Orta Anadolu'nun doğu kesimi içinde Karadeniz'e kadar uzanan ortak seramik yapımı anlayışını yansıtır92. Erken Demir Çağı'nda, Orta Anadolu'nun güney ve güney doğu kesiminde bulunan seramik malzeme benzer ortak özellikleri yansitan diğer bir kültür bölgesini oluşturur. Seramiğin ortak niteliklerine göre bir dağılım bölgesi oluşturulur ise Kaman-Kalehöyük kuzey, Tarsus Gözlükule ise güney sınırı

\footnotetext{
84 Yalçın 2013, 202-203.

85 Kozal 2010, 71.

86 Sherratt ve Sherratt 1998, 337-339.

87 Bunnens 2000, 12-19.

88 Lehmann ve Sheva 2007, 481; Koehl 2010, 81-83; Pucci 2013, 96; Pamir 2013, 179.

89 Sherratt 2013.

90 Goldman 1956, 63; Slane 1987, 470; Lehmann 2013, 324-327. Anadolu bulguları ile bağlantılı olarak yapılan antik DNA çalışmaları Geç Tunç Çağı'na kadar genetik devamlılı̆̆ın olduğunu göstermektedir (Skourtanioti et al. 2020, 1168-1F169; Ingman et al. 2021) Buna karşın, Aşkelon'da yapılan antik DNA çalışmasında Tunç Çağı' ndan Erken Demir Çağı'na geçişe ait iskelet kalıntılarında Avrupa ile ilgili genetik kalıntılar tespit edilmiştir (Feldman et al. 2019). Bu durumu Kilikya ve Amik Ovası için de kıyaslama ögesi olarak kabul edersek, Kilikya ve Amik Ovası'nda tespit edilen Geç Helladik IIIC seramiği, Doğu Akdeniz'in kültürel alandaki panoramasını anlamlı kılacaktır (Badre 2006; Venturi 2010; Ünlü 2015; Koehl 2020). Amik Ovası'nda Orta ve Geç Tunç Çağı'nda deniz/dış kaynaklı kültürel etkiler ile karşılaşılır ve bu dönemlerde kentin çok kültürlü yapısı izlenebilmektedir (Akar 2013, 38-39; Yener 2013, 20; Pamir 2013, 179-180).

91 MÖ 12. yüzyıla ait seramik malzemede kültürel çeşitlilik yerel ve Orta Anadolu kökenli nitelikler ile birleşerek devam etmiştir (Yener 2005, 6, 67, 71, 102-103, 199; Ünlü 2017, 94-98). Ancak, Amik Ovası ve Kuzey Suriye'de tespit edilen tüm seramik materyal içinde Geç Helladik IIIC dönemi seramiği yerleşim yerine bağlı değişim göstermekle birlikte daha az oranda tespit edilmektedir (Ünlü 2017, 94-95; Welton et al. 2019, 308). Monokrom seramiği yönünden Amik Ovası ile Kizzuwatna/Kilikya ve Yukarı Fırat Havzası buluntuları paralellik gösterirken (Welton et al. 2019, 301-305), boyalı Erken Demir Çağı seramiği de Levant Geç Tunç Çă̆ı seramik geleneğini sürdürür (Ünlü 2015, 523-526). Kilise Tepe'de de benzer devamlılık gözlenir (Bouthillier et al. 2014, 155-158).

92 Dönmez 2003, 224-225; Genz 2004, 26-28; Kealhofer et al. 2010, 75; Y1lmaz 2012, 72. K. Matsumura ortak kültür olgusunu Porsuk IV ve Kaman Kale Höyük IId1-3 tabakası buluntuları üzerinden yorumlayarak, Orta Anadolu Erken Demir Çağı'nda iki farklı seramik kültürü bulunduğunu savunmuştur (Matsumura 2008, 44-45).
} 
oluşturmaktadır ${ }^{93}$. Bu dönem Orta Anadolu seramiğinde, Erken ve Orta Tunç Çağı'nda uygulanmış olan biçimlendirme ve bezeme gelenekleri sergilenmiştir ${ }^{94}$. Ayrıca, Orta Anadolu'da nadir de olsa "ithal" olarak değerlendirilen Doğu Anadolu'nun yivli seramik grubuna ait örnekler bulunmuştur ${ }^{95}$. Gordion'da, Erken Demir Çağı malzemesi ile Geç Tunç Çağı arasında devamlılığın olmadığ ${ }_{1}$ bildirilmiştir ${ }^{96}$. Bu bilgilere karşın, Orta Anadolu Bölgesi'nde yönetim ve modeline dair fikir verebilecek verilerden yoksunuz.

Suriye ve Anadolu'daki şehir devletleri ile Asur ilişkilerinin başlangıcı MÖ 13. yüzyıla kadar uzanır. MÖ 10. yüzyılda Asur, önce Fırat Nehri'nin doğusundaki topraklarda sıkı bir kontrol kurmuştur. Kontrol sağlanmasıyla Yeni Asur imparatorları yazılı belgelerin yanında istila ettikleri devlet ve halklara baş eğdirmek adına askeri harekâtlar düzenlediklerini, saraylarındaki orthostatlar marifeti ile anlatmışlardır. Bu anlatımın temel noktasını, tasvir edilen olayın en etkileyici bölümlerinin gösterilmesi oluşturur. Dönemin toplumsal algısına hitap eden biçimde hazırlanmış orthostatlarda, herhangi bir yere herhangi bir anda saldırabilecek gibi görünen kralın, mağlup ettiği düşmanlarına karşı sergilediği şiddet dolu icraatları anlatılır.

Saray orthostatlarındaki şiddet sahnelerinde sergilenen dolaylı propagandanın, Asur'un saldırı düzenlediği ülkeler üzerinde kurulan denetimi ne derece etkili kıldığı tartışmalıdır. Asur gibi sınırlarını, kuruldukları bölgenin sınırlarının çok ötesine taşımış antik devletler, şiddeti birincil hakimiyet aracı olarak kullanmaktan ziyade, ilgi duydukları bölgenin niteliğine göre kuvvet uygulayarak hareket etmişlerdir ${ }^{97}$. Asurlular kendilerine sınır komşusu bölgelerde etkili bir denetim sistemi ve idari model kurmuşlar, ancak sürüp giden huzursuzlukların ve isyanların önüne geçememişlerdir ${ }^{98}$.

II. Sargon ve sonrası döneme kadar Yeni Asur Devleti'nin Tabal gibi merkezine uzak bir coğrafyadaki uygulamalarının benzer ve erken örnekleri, Aşağı Fırat ve Yukarı Dicle bölgelerinde kendisini göstermektedir ${ }^{99}$.

\footnotetext{
93 Genz 2003, fig. 1.

94 Genz 2005, 76-78.

95 Genz 2004, lev. 28,3;

96 Gunter 1991, 95-106; Henrickson 1993, 115; Henrickson 1994, 106; Voigt 1994, 267-268; Sams 1994, $19-20$.

97 Radner 2018, 13-14.

98 Baştürk 2010, 142-147. Geç Hitit Beylikleri, Asur tehdidinin ve saldırısının üzerine kendi içinde, Asur Krallığı'nın lehine ve aleyhine ittifak arayışına girişmişlerdir. Öte yandan bu beylikler kendi arasında da çekişmekte ve bir birlerinden haraç talep etmekten geri durmamaktadır (Bron ve Lemaire 1989, 35-44). III. Tiglath-Pileser, Urartu kralı II. Sarduri liderliğindeki Geç Hitit Beyliklerinin birçoğunu içeren Asur karşıtı koalisyonu yener. Benzer Asur istilaları V. Salmanassar ile II. Sargon dönemlerinde de yaşanır. II. Sargon Dönemi'nde Geç Hitit Beyliklerine ait son direnişin de kırılması ile Geç Hitit Beylikleri ele geçirilir (Hawkins 2002, 59). Bu saldırıların tümünde kitlesel sürgün bir boyun eğdirme politikası olarak uygulanmıştır (Hawkins 1975, 158-159). MÖ 705 yılında Sennaherib'in krallığı ile başlayan döneme bazı araştırmacılar tarafından "Pax Assyriaca" adı verilir (Hallo 1960, 57. Görüşün tartışması için bk. Fales 2008, 17-27).

$99 \mathrm{Bu}$ bölgelerde Orta Asur Krallığı ve ardından gelen Yeni Asur Krallığı'nın başlarında girişilen seferlerdeki amaç, yeni kazanımlardan ziyade, zapt edilmiş bölgeler üzerinde otoriteyi güçlendirmektir (Liverani 1988, 91-92; Kınal 1991, 250; Dinçol 1994, 14-15; Köroğlu 1998, 7-24; Tekin 2009, 205-206; Ökse 2015, 75-77). Benzer uygulama Orta Asur Dönemi'nde de yapılmıştır (Karg 1999, 241; Ökse 2020, 9). Bu bölgede, Asur egemenliğine giren yerlerin idaresinde Yeni Asur Devleti, farklı yönetim modellerini uygulamıştır (Parker 2001, 249-251). Yukarı Dicle Vadisi'nde, Yeni Asur Devleti'nin sınır hattında yer alan devletlerin, sınır komşusu devletler ve merkez ile olan kültürel ve ekonomik etkileşimi sağladığı ortaya koyulmuştur (Parker 2002, 391-392). Bu konuda Ziyaret Tepe kazısında bulunan seramik fırınlarından elde edilen mal, tüm seramiğin \% 24 kadarını oluştururken, formlar Nimrud ile yüzey işlenişi ise Anadolu ile ilişkilendirilmiştir (Matney et al. 2011, 536-537). Bunun yanında, yivli seramik buluntularının Orta ve Yeni Asur geçiş dönemine ait olduğu saptanmıştır (Matney et al. 2004, 391, 396; Matney et al. 2011, 538). Ziyaret Tepe'nin tablet buluntularına göre kent, eyaletin vergi toplama merkezidir (Matney et al. 2011, 542). Benzer şekilde Arslantepe kazılarında da MÖ 9. ve 8. yüzyıllarda Asur hakimiyetinin ağır bastığı bir merkez tespit edilmiştir (Liverani 2012, 338-342, tab. 1).
} 
Modern Güneydoğu ve Doğu Anadolu'da Asur varlığı, Asur'un üstünlüğü şeklinde tek yönlü hissedilirken, Orta Anadolu'da Tabal Ülkesi'nde Asur varlığı, daha "dalgalı" bir seyir izlemektedir. Bu dalgalı seyir ile Anadolu tarihinde Tabal, Asurluların yönetim uygulamalarının her çeşidinden nasibini almış bir bölge olarak karşımıza çıkar. Yazılı belgeler sebebi ile kavrayabildiğimiz bu durum, giriş bölümünde de belirtildiği gibi arkeolojik malzemede takip edilememektedir.

Tabal, MÖ 9. ve 8. yüzyıllarda yerel güçler tarafından kontrol edilen, birliğini sağlayamamış ve problemin eksik olmadığı bir bölgedir. Bölgenin söz konusu yüzyıllarına ait bilgi birikimi içinde yazılı belgeler, siyasi tarih olaylarına çok az işık tutacak düzeydedir ${ }^{100}$. Bu kültür varlıkları çoğunlukla Tabal bölgesinde kimin nereye hâkim olduğu hakkında fikir vermektedir. Buna karşın, Yeni Asur İmparatorluğu'nun belgeleri Tabal hakkında daha fazla siyasi bilgi sunmaktadır. Bu belgelerde Tabal ve Tabal'in beyleri, Asur Devleti'nin hedefi ya da Urartu veya Frigler ile Yeni Asur çatışmasının bir ögesi olarak zikredilir. Günümüzde olduğu gibi Asurlular için de Tabal bir dizi şehir devletinin bir arada yaşadığı bir bölgeyi tanımlamak için kullanılmıştır.

Her ne kadar antik dönem devletlerinin kesin sınır hatlarının anlaşılması zor olsa da antik kaynaklara göre Tabal; kuzeyde Kızılırmak (Maraşantiya/Halys) Nehri'nin güney yakası, batıda Frigya, doğuda Tilgarimmu, Melid ve Urartu ile güneyde Hilakku ve Que tarafından çevrelenmiş bir bölgedir. Tabal'in güzergahlar üstü konumu ile demir ve gümüş madeni gibi doğal kaynakları bu bölgeyi Asur, Urartu ve Frigler için çekici kılmıştır.

MÖ 10. ve 9. yüzyıllarda Asur kralları, MÖ 2. binyılda kaybettikleri Suriye ve Suriye'nin kuzeyindeki bölgeleri ele geçirerek, Asur Ülkesi'ni genişletmek için çaba içine girmişlerdir101. Bu çabanın bir sonucu olarak Tabal, MÖ 9. yüzyıl Asur kayıtlarında ganimet kaynağı olarak kendisine yer bulmuştur ${ }^{102}$. III. Salmanassar Dönemi'nde ve özellikle MÖ 856'da Til Barsip'in fethi ile Asur ordusu Furat Nehri'ni çok defa geçerek, Geç Hitit Beyliklerini yağma ve haraç seferlerine çıkmıştır ${ }^{103}$. III. Salmanassar, Til Barsip'ten sonra babasının fetihlerini pekiştirmiş ve sonrasında MÖ 836'da Tabal'e saldırmıştır. Bu saldırıda amaç, hem güç gösterisi ile gümüş, alabaster ve ahşap gibi doğal kaynakların yağmasını yapmak hem de Suriye' deki Asur varlığının sınır emniyetine yönelik ihtiyacın giderilmesini sağlamaktır. Salmanassar'ın saldırılarından birisi Tabal'e doğu istikametinden, Melid üzerinden gerçekleşmiş ve modern Kayseri Ovası'na (Kululu-Sultanhan-Kültepe) lokalize edilen, sonradan Bit-Purutaş olarak tanınacak Tuatti' nin krallığı üzerinde yoğunlaşmıştır ${ }^{104}$. Salmanassar'ın burada uyguladığı muhtemel strateji, Tabal Ülkesi'ne girdikten sonra ülkenin diğer şehir krallıklarına gözdağı vermek için en büyük krallığa saldırmasıdır ${ }^{105}$. Kral, ülkeye boyun eğdirdikten sonra tüm şehir krallıklarını vergiye bağlar. Bu durum Asur açısından tam bir başarıdır. Belgelerde, bu saldırı sonucunda Salmanassar'ın Tabal Ülkesi'nin Asur karşısındaki statüsü ve buradan alınan haracın/verginin miktarı ve biçimi hakkında bilgi verilmez ${ }^{106}$. Bu saldırı ile ilgili Asur kayıtları Tabal Ülkesi'nde bulunan tahkimatlı yerleşimler ile ilgili bilgi verir ${ }^{107}$. Bu bilgi, ülkenin yerel beyleri arasında çekişmenin

\footnotetext{
100 Hawkins 2000, 433 vd.

101 Postgate 1992, 247. Postgate, Asur tarihini 4 safhaya ayırır. Söz konusu dönem Asur tarihinin 3. safhasıdır.

102 Hawkins 2000, 425-426.

103 Fuchs 2002, 595

104 Hawkins 2000, 427.

105 Akçay 2014, 38. T. Yiğit, Tuatti'nin bölgenin ileri gelen bir figürü olması fikrine karşı çıkar (Yiğit 2000, 178).

106 Yiğit 2000, 178.

107 Polacco 1973, 38-39. Bölgede bulunan yerleşimlerde hem tahkimat hem de sınır duvarları tespit edilmiştir (Aro 1998, 160-165; Şenyurt 2010, 236; Şenyurt et al. 2014, 104-105).
} 
bulunduğunun göstergesi olarak yorumlanmıştır ${ }^{108}$. Tespit edilen sınır duvarları, Tabal Ülkesi içindeki kesin taksime işarettir ${ }^{109}$.

Salmanassar'ın yaşlanması ile birlikte, idaresinin son yıllarında siyasi çalkantı başlar ve bu durum devlet için zafiyet meydana getirir110. Zafiyet sonucunda oluşan boşluk, Urartu kralı Menua tarafından doldurulur ve kral önce Melid'e ve ardından "Hate/Hatti Ülkesi'ne" saldırır. Menua'nın oğlu Argisti de ordusunu Melid üzerinden batıya ve Tabal'e "Tuatehi/Tuatti Boyu'nun/Oğulları' nın Ülkesine" sürerek, haraç talep eder111. Argisti yazıtı, Tabal Ülkesi'ndeki beyler hakkında herhangi bir bilgi içermez, ancak Tuatehi/Tuatti'nin torunlarına değinilmesi, MÖ 9. yüzyılın sonu ve 8. yüzyılın ilk yarısında Tabal'in doğu ve kuzeydoğusunda aynı ailenin egemenliğinin sürdüğünü gösterir.

MÖ 8. yüzyılda Urartular, Asurluların hem kuzeybatıdaki vasal devletleri için hem de kuzey sınırları için bir tehditti. II. Sarduri Dönemi'nde Kummuh, Urartu'ya teslim olmaya zorlanırken, Arpad, Melid ve Gurgum Urartu yanlısı, Asur karşıtı ittifaka katıld1112. Uratuların Fırat Nehri'ne kadar ulaşması üzerine yeni tahta çıkan III. Tiglath-Pileser, ilk iş olarak Melid dahil olmak üzere Urartuları MÖ 743 yılında yendi ve devamındaki yıllarda Firat Nehri'nin batısında bulunan beylikleri idaresi altına aldı veya vasal hale getirdi ${ }^{113}$. Bu gelişme sonrasında Urartu Krallığı'nın batı sınırlarına da erişmesini engellemek isteyen Asur, Tabal gibi Anadolu bölgeleri ve beylikleri üzerinde denetim kurmak zorunda kaldı. Bu dönemde Topada Wasusarma/Uassurme yazıtında $11^{114}$ ve Asur kayıtlarına göre 9 "kral" Tabal Ülkesi'nde bulunmaktadır115.

Tabal'in coğrafi olarak kısmen korunaklı olması ve çatışma bölgesine uzak olması, Asur ya da Urartuların ülkeyi elinde tutmasını güçleştiriyordu. III. Tiglath-Pileser'in Anadolu'nun bu bölgesinde Urartu Krallı̆̆ı'nı tehdit olmaktan çıkarması, Tabal krallarının Asur Krallığı'na haraç ödemesi ile sonuçland1116. Asurlular bu durumu sinırlı askeri müdahale ve kısmen de diplomasi yolu ile başardılar.

Topada yazıtında, Wasusarma/Uassurme'nin anlatımına göre, kralın kendisiyle birlikte Warpalawa, Kiyakiyas ve Ruwatas'dan oluşan ittifak karşısında sekiz kraldan oluşan müttefiklerin bulunduğu bilgisi verilmiştir. Asur belgelerine göre Tabal Ülkesi geneline yayılmış olan bu çatışma durumundan bağımsız olarak Wasusarma/Uassurme'den başka sekiz kral daha III. Tiglath-Pileser'e haraç ödemektedir117. Bu kralların Asur'a haraç ödemesi, aralarındaki iç çekişmelere son vermemiş118, Asur kralları da bu çatışmalara müdahil olmamıştır119. MÖ 730-729 civarında, Wasusarma/Uassurme haracını ödemeyerek, bir anlamda Asur kralına isyan ettiğinde, Asurlular Wasusarma/Uassurme'i tahttan indirip yerine, belgelerde "hiç kimsenin oğlu" olarak tanıtılan Hulli'yi çıkarırlar120. Asur

\footnotetext{
108 Melville 2010, 88-89.

109 Şenyurt ve Akçay 2018, 107, 110.

110 Köroğlu 2006, 162-164.

111 Hawkins 2000, 427; Kurt 2010a, 130.

112 Özkan 1993, 73-75.

113 Hawkins 1982, 410-413; Garelli 1991, 47-48.

114 Hawkins başka bir yayınında bu rakamı yazıt belirtilmeksizin 10 olarak verir (Hawkins 1982, 413).

115 Nineveh ve Kalhu kayıtlarına göre (http://oracc.org/saao/P336799/.); (http://oracc.org/rinap/Q003428/);

Hawkins 2000, 452-453.

116 Weeden 2010, 41-42.

117 http://oracc.org/saao/P336799/.

118 Şenyurt ve Akçay 2018, 101-102.

119 Weeden 2010; Hawkins 2000, 430-431. Topada yazıtında, Wasusarma/Uassurme ile birlikte üç müttefik kralın sekiz adet isim belirtilmeyen krala karşı savaştığı bir sınır çatışması anlatılmaktadır.

${ }^{120}$ Luckenbill 1926, 288, no. 802.
} 
belgelerinde Wasusarma/Uassurme'nin haraç ödememesine neyin sebep olduğu anlatılmaz. Fakat sorun ne olursa olsun Asur İmparatorluğu'nun Tabal Ülkesi'nin "büyük kralını" değiştirmesi sorunları çözmemiştir ${ }^{121}$. S. Y. Şenyurt ve A. Akçay, Topada yazıtında anlatılan çatışma sürecinin V. Salmanassar Dönemi'ne kadar uzandığını savunur ve bu bağlamda iki ittifak arasındaki mücadelede Hulli'nin yenilmesini, arkasında Asur desteğini alamamasına bağlar ${ }^{122}$. Bu durum, Tabal'de Asur'un müttefikleri karşısında yerel müttefiklerin varlığına işaret eder. S. Melvile ise Asur karşıtı veya destekçiliği olgusuna değinmeden, Wasusarma/Uassurme'nin yardımına Tabal krallarının koşmadığını söyler ${ }^{123}$. Tüm bu mücadeleye rağmen Wasusarma/Uassurme'nin tahtan indirilmesi Asur İmparatorluğu'nun Tabal Ülkesi üzerindeki gücünü göstermesi bakımında önemlidir.

Tabal beyleri bu süreçte "büyük kral" olma ve topraklarını genişletmede başarılıdırlar ${ }^{124}$. Böylece kendilerinde, geçmişlerine atıf yapacak kuvveti bulup, anıtsal eserlerin yapımına başlamış olmalıdırlar ${ }^{125}$. Tabal Ülkesi'nde bulunan anıtların Hartapu Grubu $^{126}$ haricindekilerin tümü MÖ 8. yüzyılın 2. yarısına, yani Tabal'in vasal ülke statüsüne geçişinden sonraya aittir ${ }^{127}$. Bu yeni durum, Tabal Ülkesi'nde ancak zenginleşme sonucu ortaya çıkabilir ${ }^{128}$. Kululu heykelleri bu varlık artışının bir sonucudur.

II. Sargon, MÖ 721 yılında Asur tahtına çıktığında, Urartu Krallığı'nı ve Frig Krallığı'nı Asur'un vasal devletlerine ve kuzey sınırlarına yönelik bir tehdit olarak bulur. Asur Krallığı'nın bu tehdidi savuşturmak adına yaptığı ilk iş, Tabal ile birlikte Melid ve Que' nin kontrolünü korumak olmuştur. Kral, MÖ 718'de Sinuhtulu Kiakki'yi tahttan indirir ve Sinuhtu'yu Atunnalı Kurti'ye verir ${ }^{129}$. Sargon, Hulli'nin oğlu Ambaris'i hem Bit-Purutaş kralı hem de kızı Ahatabisa ile evlendirerek damadı yapar ve Hilakku'yu kızına çeyiz olarak verir. Sargon bu suretle bölgede çok parçalı bir yapı meydana getirirek, bir güç dengesi oluşturmayı amaçlar. Sargon'un uygulamalarına bakılırsa, vasal bir Bit-Purutaş/Tabal görmek istemiştir. Buna karşın, Asur belgelerinin anlattığına göre Ambaris ve Kurti'nin de dâhil olduğu Tabal kralları, Muşkili Mita ve Urartulu Rusa ile işbirliğine giderek, Asurluları Tabal'den çıkarmak üzere harekete geçer ${ }^{130}$. Ancak Sargon bu isyanı bastırır ve Bit-Purutaş'1 resmen Asur eyaleti statüsüne düşürür ${ }^{131}$. Eyalet olma sürecinde Kiakki'nin isyanı sonucunda esaret altına alınmasının ve MÖ 714 yılında Sargon'un Urartuları yenmesinin Ambaris'te bir tedirginliğe sebep olup, Muşkili Mita ile işbirliğine yakınlaştırmış olabileceği önerilmiştir ${ }^{132}$. Olayların seyri, diğer Tabal kralları arasında Ambaris açısından farklı olmalıdır. Çünkü Ambaris, Dur Sarrukin krali belgelerine göre Asur'da büyümüş ve sonrasında Sargon'a damat olmuştur ${ }^{133}$.

\footnotetext{
121 Şenyurt ve Akçay 2018, 102-103.

122 Şenyurt ve Akçay 2018, 103.

123 Melville 2010, 93.

124 Simon 2017a, 174-175; Simon 2017b.

125 Melville 2010, 94.

126 Akçay 2016.

127 Hawkins 2000, 429.

128 Simon 2017b.

129 Kurt 2010b, 73.

130 Winckler 1889, 29-31.

131 Yiğit 2000, 184; http://oracc.org/saao/P224485/. Hubisna'nın durumu ise Asur kaynaklarına göre belirsizdir (Hawkins 2000, 428). Bu dönemde Yeni Asur Krallığı merkezini, modern Kayseri Ovası'nın oluşturduğu BitBurutas/Tabal ile merkezini Bor Ovası'nın oluşturduğu Tuwana'ya kadar resmen genişletmiştir (Baydur 1970, 86). T. Bryce, Bit-Purutas'1 Karaman'ın kuzeyi ile Kayseri arasını önerir (Bryce 2012, 144).

132 Melville 2010, 97-98.

133 RINAP: Royal Inscriptions of the Neo-Assyrian Period; http://oracc.museum.upenn.edu/rinap/qpn-xpeople\#Q006482.164, Sargon II 001, Q006482, 194b, 198 b.
} 
İlk başta bu yeni dönem Asur'un alternatiflerini de ortaya çıarmış gibi görünüyor olsa da Tabal kralları için siyasi gücün sürdürülmesi adına oldukça sıkıntılı bir süreç olduğuna şüphe yoktur. Bu döneme ait Asur kaynakları, Tabal'in kontrolü için mücadelenin sürdüğünü gösterir. Böylece Tabal bölgesi MÖ 8. yüzyılın sonlarına doğru bir kez daha güçlü krallıkların çatışma alanı içinde kalır.

$\mathrm{Bu}$ olaylardan sonra Asur kaynakları Sargon'un, bir kısmı Asurlu olmak üzere Kargamış ve civarından göçmenleri Bit-Purutaş'a getirtip, yöneticileri ile beraber buraya yerleştirdiğini bildirir ${ }^{134}$. Fakat yeni yerleşimcilerin ülkedeki varlığ1 ve Ambaris'in yöneticilikten uzaklaştırılması sorunları çözmemiştir.

Asur-sarru-usur'a II. Sargon'dan gelen mektupta, Que-Urartu ve Frig-Asur ilişkileri dışında Atunna ve Istuanda Beyliklerinin Tuhanalı Urpalla'nın ve Bit-Purutaş'ın bazı kentlerini yani Asur Devleti'nin toprağını aldığı anlatılır'135. Mektuba göre, Asur eyaletinin bir parçası olduğu iddia edilen toprakların iki farklı Tabal Ülkesi kralı tarafından alınması, Asur'un Tabal kralları üzerinde sıkı bir kontrolü olmadığını göstermektedir. Ayrıca Tabal kralları dönemin üç büyük gücü ile de temas halindedir. Fakat söz konusu mektuba göre Midas'ın II. Sargon ile anlaşması, Tabal krallarını tamamen yalnız bırakmış, dahası Sargon mektubunda Frigler ile birlikte Tabal beylerine karşı bir saldırının sinyalini vermiştir ${ }^{136}$.

Kral mektubunda bildirdiğini yaparak, Bit-Purutaş'a gelir ve burada MÖ 705 yılındaki savaşta ölür. Kralın ölümü ile birlikte Tabal Ülkesi'nde Asur egemenliği son bulur137. Kimi araştırmacılar bu savaşı ve II. Sargon'un ölümünü Kimmer-Asur çatışmasına bağlar138. Buna karşın, Asur belgelerinde Tabal krallarının ve ülkesinin Kimmer-Asur çatışmasının bir parçası olduğuna dair kesin beyan yoktur139. MÖ 7. yüzyıl ile beraber Asur'un ülkeden çekilmesini takip eden süreçte, Kimmer tehdidi ve buna bağlı Urartu ve Frigya'nın yıkılışı, Anadolu'nun tüm güç dengesini değiştirir.

Tabal, MÖ 7. yüzyılın Asur kayıtlarında; Assarhadon Dönemi'nde Kimmerler ile Asur Krallığı'na karşı birlik olan ve Asurbanipal Dönemi'nde ise Asur'a savaşsız teslim olup haraç ödeyen bir bölge olmak üzere iki zıt anlatım ile yer alır ${ }^{140}$. Her iki kralın kayıtlarında Tabal krallarının Anadolu'nun diğer kralları ile Asur'a karşı işbirliği içinde olduğu anlaşılmaktadır ${ }^{141}$.

Tabal Ülkesi'nin kronik çok parçalı siyasi yapısı, Tabal'in siyasi varlığının ortadan kalkması ile sonuçlanacak sürecin temelini oluşturmuş olmalıdır. Boğazköy ${ }^{142}$, Alişar ${ }^{143}$ ve tartışmalı olmakla beraber Gordion'da ${ }^{144}$ tespit edilen Kimmer akınlarının tahribatına dair

\footnotetext{
134 Tabal'de yapılan arkeolojik çalışmalarda Kululu (Özgüç 1971, 48) ve Göllüdağ'da (Tezcan 1968, 219) bulunan heykeltıraşlık örnekleri ile Kültepe'de (Özgüç 1971, 12) ve Kululu'da (Özgüç 1973, 13-15) bulunan mühürler haricinde Yeni Asur sanatını anımsatacak yabancı bir kültüre ait ögelere henüz rastlanmamıştır. Kululu'da bulunmuş söz konusu heykeltıraşlık eserleri Geç Hitit denilen beyliklerin hemen hemen tamamında karşımıza çıkan heykeltıraşlık eserlerinin MÖ 8. yüzyılın 2. yarısına ait Geç Hitit veya Suriye-Hitit stili ile uyumludur. Buna karşın Akçay, Sargon Dönemi'nde gerçekleştirilen zorunlu göç olgusunun kültürel değişime yol açmış olabileceğini savunur (Akçay 2020, 25-26).

135 Postgate 1973, 23-25.

136 Postgate 1973, 25.

137 https://www.ucl.ac.uk/sargon/essentials/kings/sargonii/

138 Hawkins 2000, 428; Toptaş 2020, 40.

139 Berndt-Ersöz 2008, 22, dn. 104.

140 Tansuğ 1949, 536-537; Starr 1990, 12-13; Yiğit 2000, 185-186. Tabal'in Kimmer kralı Tugdamme yanında Asur'a karşı yer alması, bu duruma sebep olmalıdır (Cogan ve Tadmor 1977, 84).

141 Starr 1990, LVIII.

142 Bittel ve Güterbock 1933, 36; Neve 1982, 147; Bossert 2000, 158-159.

143 von der Osten 1937, 323.

144 Young 1955, 16; Manning et al. 2001.
} 
belgeler, Tabal bölgesi yerleşimlerinden Ovaören'de ${ }^{145}$ tespit edilmiştir ${ }^{146}$. Anadolu'nun diğer devletleri için de yıkım getiren bu olayın seyri, Asur kaynaklarına göre Kimmer-Tabal işbirliği şeklinde gelişmiştiri47. Tabal kültürel varlığının göstergesi olan seramiklerinn ${ }^{148}$ ve siyasi varlığının karakteristik özellikleri olan kaya kabartmaları, steller ve yazıtların bölgede görülmemesini, Kimmer işbirliğinin uzun vadeli olumsuz etkisi olarak düşünmekteyiz.

Tabal'in bu son dönemi Asur Krallığı penceresinden değerlendirildiğinde, Doyle'ın sistemik imparatorluk modeli önerisine göre güvenlik arayışının temel kaygı olduğu görülür ${ }^{149}$. Bu bağlamda, Tabal bölgesinde görülen ekonomik yıpranmanın oluşmasının arkasında, Asur'un Frigya kaynaklı güvenlik endişesinin daha kötü bir hal almasını önermek isteriz. Asur'un kuzey ve doğu sinırları için ortaya çıkan Kimmer tehdidine iki cephede savunmaya geçilmesi, Tabal yerel güçlerine olan desteğin çekilmesi sonucunu doğurmuş olabilir.

Kimmer saldırısından önce Orta Anadolu'nun kontrolü için Asur, Frigya ve Urartu arasındaki rekabet, Tabal ekonomilerini bastırmaktan ziyade geliştirmiş olmalıdır. Sonuç olarak, Demir Çağı Önasyası'nın üç büyük gücü Tabal Ülkesi'nden demir ve gümüş gibi yüksek değerli malzemelerin düzenli olarak tedarik edilmesini talep etmişlerdir. Asur'un Tabal bölgesi üzerinde olanca ağırlığının hissedildiği zamanlardan farklı olarak, MÖ 7. yüzyılda söz konusu yüzyılın neredeyse tamamına yayılacak şekilde hiyeroglif yazıtlar ile diğer anitsal eserlerin ortadan kalkmas1 ${ }^{150}$, Asur ile kurulan emperyal ilişki çerçevesinde değerlendirilebilir.

\section{Sonuç}

Erken Demir Çağı' nda Geç Hitit coğrafyasının güney ve kuzey bölgelerinde, hanedan ailelerinin varlığı sürmektedir ${ }^{151}$. Bu coğrafyanın güneyi ile Aşağı ve Yukarı Firat havzalarında yapılan araştırmalarda tespit edilen bu hanedanlar, Hititlerden devraldıkları, idare anlayışının bir devamı olarak ${ }^{152}$ kıymetli ticari metanın tekelini ellerinde tutmuş olmalıdırlar. Ticaret, her beyliğin elit kesiminin paydaşı olduğu bir zümrenin tekelinde sürmüş olabilir. Ancak tekelleşmenin Tunç Çağı'na göre farkı, tek bir sarayın istifadesi yerine çok paydaşlı (hatta kabilelerin de işin içine dahil olduğu) yapının ortaya çıkmasıdır ${ }^{153}$. Dönemin kral veya beylerinin ortak çıkarları gereği kıymetli malların ticareti denetlenirken, çanak-çömlek gibi ticaretin daha az önemli unsurlarının pazarda yer almasına izin verilmiş olmalıdır. Bu sistem, Doyle tarafından önerilen taşra ya da perifer modeli imparatorluk yönetimi ile benzer noktalara sahiptir.

Tabal Ülkesi'ne ilki MÖ 9. yüzyıl ortalarında Asur, ikincisi MÖ 8. yüzyılın ilk yarısında Urartu olmak üzere dış güçlerin müdahalesi görülür. Söz konusu saldırılarda

\footnotetext{
145 Akçay 2015, 53.

146 Göllüdağ'ın durumu ise çok şüphelidir. Göllüdağ kazı raporunda iki tabanın tespit edildiği ve altta bulunan ikinci tabanın yangın geçirdiği bilgisi verilmekte ve bu tabanın hemen üzerinde bir taban bulunduğu anlatılmaktadır (Tezcan 1968, 216; Tezcan 1992, 1-11). Ancak tek başına yangın geçirmiş bir tabanın tespit edilmesi, kentin Kimmer tahribi için yeterli kanıtı oluşturmaz. Göllüdağ hakkında bk. Şenyurt ve Akçay 2018, 105-106.

147 Tansuğ 1949, 540-541; Toptaş 2020, 41-42, 50. Bilindiği gibi Anadolu'da Kimmer varlığına delil olarak kabul edilen buluntular Tabal bölgesi dışında Lydia, Urartu ve Orta Karadeniz Bölgesi ile krallıklarında da görülmektedir (San 2000).

148 Şenyurt et al. 2019, 227.

149 Doyle 1986, 125.

150 Hawkins 2000, 433.

151 Müller 2005, 112.

152 Yener 1995, 101-107; Cordani 2016, 162-163.

153 Bunnens 2000, 13, 16.
} 
amaç, Tabal Ülkesi'nin doğal kaynaklarını sömürmektir. Asur kralı III. Salmanassar ve Urartu kralı I. Argisti çağdaşları olan krallar ile Tabal Ülkesi'nde savaşmamıştır. Ayrıca bu krallar Tabal için de savaşmamışlardır. Dolayısıyla, Tabal Ülkesi her iki devlet için esas hedef olarak görünmemektedir. Bu devletler tarafından Tabal, yoğun askeri çaba ve maliyete değmeyecek, ancak sömürgeleştirilmeye uygun bir ülke olarak görülmüş olmalıdır.

III. Salmanassar Dönemi Asur kaynaklarında yirmi krallıktan söz edilirken, bu sayı, MÖ 8. yüzyılın ortalarına ait Asur kaynaklarında dokuz krala düşer. Bu durum ülke içinde vasal krallıklarda oluşan bir yapılanmanın ortaya çıktığını gösterir. Bu bilgi ışı̆̆ında Asur istila dalgalarının, Tabal Ülkesi beylerinin birlik olma sürecini de hızlandırmış olabileceği söylenebilir. Aynı zamanda kral sayısındaki azalma, Tabal krallarından bazılarının sivrilerek, kendi bölgesel hegemonyalarını kurmuş olabileceklerini düşündürmektedir. Bu durum, dönemin emperyal dünyasının işleyişinin ülke içindeki sonucu olarak görülebilir ${ }^{154}$.

Tabal'in MÖ 850'ler ile MÖ 750'ler arasındaki dönemini ülke içindeki politik olguları bir kenara bırakarak, "dolanıklık teorisinin” öngördüğü işleyiş içinde Anadolu'nun diğer bölgeleri ile olan ilişkilerinden yola çıkarak değerlendirmek mümkündür. Fakat aynı zamanda bu dönemin siyasetini bir sistem içinde izah etmek istediğimizde, karşımıza modern dünya sistemi teorisinin periferine hakim olan çekirdek devlet modeli çıkmaktadır. Yazılı kaynakların ifadelerine göre bu dönem eşitsiz değişime dayalı çekirdek-perifer ilişkisidir. Aynı tarih aralığı içinde, Tabal Ülkesi ile Asur Krallığı arasında kolonicilik faaliyeti ilişkisi sınırları içinde değerlendirme yapmayı mümkün kılan yeterli veri bugün için yoktur. MÖ 8. yüzyılın ikinci yarısında Asur ve Urartu arasında artan rekabet, Asur'un PitPurutaş'1 vasal devleti haline getirmesi için sebep olur. Tabal için sancılı geçen Wasusarma/Uassurme'nin azil sürecinde yaşanan olayların, antik çă̆ emperyalizminin sonraki dönemlerinde de karşılaşılacak bir durum olan; ismen bağımsız gibi görünen krallıkların büyük devlet ile girdikleri ilişki sonucunda ortaya çıkan "gayriresmi" imparatorluk sistemi dahilinde gerçekleştiğini önermek isteriz. Bu durum Yakındoğu'da Roma' nın baş eğdirdiği devletlerin idaresinde de kendisini gösterir. Doyle, Montesquieu'nun görüşlerine nispet ederek ortaya koyduğu yaklaşımda, Roma'nın istila ettiği bir yerde önce özgürlüğe izin verdiğini, bu durumun özgürlüğü isteyen ve Romalıların iradesinden başka irade olmadığını savunan iki fraksiyonun ortaya çıkmasına sebep olduğunu anlatır. Roma'yı savunan grubun her zaman daha güçlü olduğunu, bunun için galip geldiğini ve bunun yavaş bir fetih yolu olmakla beraber, düşmanda uzun süreli bir zayıflık oluşturduğunu belirtir. Teslimiyetin en son aşamasında ise kayıtsız bir şekilde Roma'nın fethettiği yeri zayıflatan koşulların dayatıldığını söyler ${ }^{155}$.

$\mathrm{Bu}$ sisteme göre periferin iç düzenini sağlayacak güce sahip olması, fakat bağlı bulunduğu çekirdeğin çıkarlarına zarar verebilecek güce kavuşmamasını sağlamak esastır156. Bu noktada imparatorluk sisteminde çekirdek devletin perifer ile olan ilişkilerini tehdit ve destekleme dengesi içinde oluşturduğu açıktır157. Bu bağlamda Algaze'nin ortaya attığı Uruk dünya sistemi teorisinin temelinde bulunan ve esasen ticari faaliyet ile ilişkilendirilen bağımlılık ve emperyalizm, Yeni Asur kralları tarafından siyaset ve diplomasi alanlarında tam anlamı ile uygulanmıştır.

Wallerstein'a göre emperyal güç açısından ideal olanı, haraç ve diğer yükümlülükler yerine getirilirken perifer devleti doğrudan yönetmek zorunda kalmadan, ülkeyi idare

154 Melville 2010, 88-89.

155 Doyle 1986, 90-94.

156 Doyle 1986, 13.

157 Doyle 1986, 38. 
etmektir. Bu nedenle perifere yapılması zor yükümlülükler vermek ters etki yaratacaktır ${ }^{158}$. $\mathrm{Bu}$ yaklaşım antik döneme uyarlanırsa, Tabal'in egemen yerel güçlerinin, III. TiglathPileser'in himayesinde gelişirken "büyük kral" ve "kahraman" olmaları ve böyle anılmaları, Asur kralının tanıdığ1 bir "özgürlük" olarak görülebilir159. Bölgede Tuwana kralları ise "kral" ve "kahraman" olarak anılır. Bu durum belki de Asur desteğini arkasına alan krallar arasındaki hiyerarşinin bir sonucudur ${ }^{160}$. Periferi kontrol altında tutmak adına geliştirilen modelde, antik devletler uzak ülkelerin yerel hanedan ailelerinin idari düzenleme içine dahil edildiği yönetim modelini ortaya koymuştur. Bu modelin temelinde, iyice genişlemiş ülke sınırlarının güvenliğinin sağlanması adına esnek idari ve ekonomik yöntemler geliştirilmesi bulunmaktadır ${ }^{161}$.

Tabal Ülkesi'nin çok parçalı siyasi yapısı yerel beylerin güçlü olmasını engelleme, bu beylerin birleşmesini engelleme, Frig ve Urartu krallıklarının ülkedeki faaliyetlerini engelleme gibi bir dizi mecburiyeti de Asur Devleti'ne yüklemiştir. Bu mecburiyetlerin altında kalan Tabal'in beyleri arasındaki rekabetin yoğunlaşması, kendilerini bilinir kılma isteklerini arttırmış ve suretle anıtlar ve yazıtlar yaptırmalarını teşvik etmiştir.

Tabal'in Asur eyaleti olması, daha önceki bir dönemde Asur'da dahil olmak üzere hiçbir gücün kalkışmadığı bir durumdu. Asur bu hareketi ile gerektiğinde Tabal gibi uzak bir coğrafyada olsa bile egemenliğinden taviz vermeyeceğini açıkça göstermiştir. Ne var ki Asurluların Tabal Ülkesi' nde çıkan sorunların çözümüne yönelik askeri, ekonomik ve politik ögelerin herbirini ayrı bir seçenek olarak uygulamalarının altında yatan sebep, mesafedeğişim oranı teorisinde görülen maliyet unsurudur ${ }^{162}$. Maliyetten kaçınmak adına Tabal bölgesi beylerine kraliyet ailesi ile evlilik, başka bölgelerin topraklarının armağan edilmesi ve diplomasi, bu konuda yardımcı olmuş olmalıdır. Böylece istila edilen ya da vasal krallığa dönüştürülen memleketlerde ekonomik kaynakların sömürülmesi, işleyen bir sistem içinde yürütülmüş olacağı hesap edilmiştir. Tüm bunlara rağmen Ambaris olayı sonucunda Tabal Ülkesi resmen ilhak edilir. Asur'un Tabal ile ilgili yaklaşımı toplamda 150 yıllık sürede aşama aşama gerçekleşen ilhak olgusunun aslında Asur tarafından arzu edilen bir sonuç olmadığıdır. Asur'un sınır komşusu bölgeler için oluşturduğu kontrol mekanizmasının Tabal gibi daha uzak coğrafyalarda etkili olmadığı, çıkan isyanlardan anlaşılmaktadır.

\footnotetext{
158 Wallerstein 1974, 57-59.

159 II. Tuati; Kululu, Çiftlik, Topada, Kayseri yazıtlarında ve Wasusarma/Uassurme; Topada, Suvasa, Sultanhan ve Kayseri yazıtlarında “büyük kral” ve "kahraman" ünvanları ile yer alırken Göstesin yazıtında sadece ismi okunmaktadır.

160 Tuwana krallarından; Saruwani Andaval yazıtında, Muwaharani Bor yazıtında ve Warpalava; İvriz, Bor, Bulgarmaden, İvriz II, Niğde II, Topada stel, yazıt veya anıtlarında ve II. Muvaharani Niğde stelinde "kral" ünvanı ile yer alır.

161 Parker 2006, 83-91.

162 Parker 2001, 252-253. Mesafe-değişim oranı teorisine göre merkezi otoritenin uyguladığı askeri, ekonomik veya politik her türlü girişimin maliyeti, bu girişimin merkezden uzaklığıyla orantılı olarak artar. Bu durumda ekonomik zorlanma kaçınılmazdır (Stein 1999b, 171-175).
} 


\section{Bibliyografya}

Akar, M. (2013). The Late Bronze Age Fortresses at Alalakh: Architecture and Identity in Mediterranean Exchange Systems. K. A. Yener (Ed.) Across the Border: Late Bronze Age-Iron Age Relations between Syria and Anatolia, Proceedings of a Symposium held at the Research Center of Anatolian Studies, Koç University, İstanbul, May 31-June 1, 2010 (ss. 37-61). Peeters.

Akçay, A. (2014). Tabal Ülkesinin Tarihsel Süreci Üzerine Bir Değerlendirme. Tarih İncelemeleri Dergisi, 29(1), 37-58. https:/ / doi.org/10.18513/egetid.69160

Akçay, A. (2015). Ovaören-Yassıhöyük'den Bir Yarı İkonik İdol. Arkeoloji ve Sanat, 149, 47-54.

Akçay, A. (2016). Hartapu: Kimin Kralı?. S. Erkut ve Ö. Sir-Gavaz (Ed.) Studies in Honour of Ahmet Ünal Armă̆anı (ss. 9-25). Arkeoloji Sanat Yayınları.

Akçay, A. (2020). Tabal Heykeltraşlık Eserleri Üzerine Genel Bir Değerlendirme. Ankara Hacı Bayram Veli Üniversitesi Edebiyat Fakültesi Dergisi, 2, 11-28.

Akın, S. (2015). A Review on the Roots of Marxist Approach in Archaeology. International Journal of Archaeology. 3(4), 33-38. https://doi.org/10.11648/j.ija.20150304.11

Akkermans, P. M. M. ve Schwartz, G. M. (2003). The Archaeology of Syria: From Complex Hunter-Gatherers to Early Urban Societies (c.16,000-300 BC). Cambridge University Press.

Albayrak, İ. (2018). Eski Asurca Kaynaklara Göre Asur-Anadolu İlişkilerinde Hahhum Krallı̆̆ı' nın Önemi. Archivum Anatolicum, 12(2), 1-11.

https://doi.org/10.1501/Archv_0000000149

Algaze, G. (1993a). The Uruk World System. The Dynamics of Expansion of Early Mesopotamian Civilizaton. The University of Chicago Press.

Algaze, G. (1993b). Expansionary Dynamics of Some Early Pristine States. American Anthropologist, 95(2), 304-333.

Algaze, G. (2001). Initial social complexity in southwestern Asia: The Mesopotamian advantage. Current Anthropolgy, 42(2), 199-233. https://doi.org/10.1086/320005

Algaze, G., Brenties, B., Knapp, A. B., Kohl, P. L., Kotter, W. R., Lamberg-Karlovsky, C. C., Schwartz, G. M., Weiss, H., Wenke, R. J., Wright, R. P. ve Zagarell, A. (1989). The Uruk Expansion: Cross-cultural Exchange in Early Mesopotamian Civilization [with Comments and Reply]. Current Anthropology, 30(5), 571-608.

Allen, M. (1992). The Mechanisms of Underdevelopment: An Ancient Mesopotamian Example. Review (Fernand Braudel Center), 15(3), Comparing World-Systems, 453-476.

Allen, M. J. (1997). Contested Peripheries: Philistia in the Neo-Assyrian World-System. [Yayımlanmamış Doktora Tezi], University of California.

Alp, S. (2002). Hitit Çă̆ında Anadolu. TÜBİTAK Yayınları.

Areshian, G. E. (2013).Variability and Complexity in Multidisciplinary and Interdisciplinary Studies of Empires. G. E. Areshian (Ed.) Empires and Diversity: On the Crossroads of Archaeology, Anthropology, and History (ss. 1-20). UCLA.

https://doi.org/10.2307/j.ctvdjrqgq.6 
Aro, S. (1998). Tabal: Zur Geschichte und materiellen Kultur des zentralanatolischen Hochplateaus von 1200 bis 600 v. Chr. [Yayımlanmamış Doktora Tezi], University of Helsinki.

Atıc1, L. (2014). Food and Ethnicity at Kültepe-Kanesh: Preliminary Zooarchaeological Evidence. L. Atıc1, F. Kulakoğlu, G. Barjamovic ve A. Fairbairn (Ed.) Current Research at Kültepe/Kanesh: An Interdisciplinary and Integrative Approach to Trade Networks, Internationalism, and Identity (ss. 195-213). Lockwood Press. https://doi.org/10.2307/j.ctvvnd58

Barde, L. (2006). Tell Kazel-Simyra: A contribution to a relative chronological history in the Eastern Mediterranean during the Late Bronze Age. BASOR, 343, 65-95.

Barjamovic, G. (2011). A Historical Geography of Anatolia in the Old Assyrian Colony Period, Museum Tusculanum Press.

Barjamovic, G. (2017). A Commercial Geography of Anatolia: Integrating Hittite and Assyrian Texts, Archaeology and Topography. M. Weeden ve L. Z. Ullmann (Ed.) Hittite Landscape and Geography (ss. 311-319). Brill.

Barjamovic, G. (2018). Interlocking Commercial Networks and the Infrastructure of Trade in Western Asia during the Bronze Age. K. Kristiansen, T. Lindkvist ve J. Myrdal (Ed.), Trade and Civilisation: Economic Networks and Cultural Ties, from Prehistory to the Early Modern Era (ss. 113-142). Cambridge University Press. https:/ / doi.org/10.1017/9781108340946.006

Barjamovic, G., Hertel, T. ve Larsen, M. T. (2012). Ups and Downs at Kanesh: Chronology, History and Society in the Old Assyrian Period. Leiden.

Barjamovic, G., Chaney, T., Coşar, K. ve Hortaçsu, A. (2019). Trade, Merchants and the Lost Cities of the Bronze Age. The Quaterly Journal of Economics, 134(3), 1455-1503.

Barnett, H. G., Broom, L., Siegel, B. J., Vogt, E. Z. ve Watson, J. B. (1954). Acculturation: An Exploratory Formulation The Social Science Research Council Summer Seminar on Acculturation, 1953. American Anthropologist, 56(6), 973-1000.

Bartl, K. (2001). Eastern Anatolia in the Early Iron Age. R. Eichmann ve H. Parzinger (Ed.) Migration und Kulturtransfer: Der Wandel vorder- und zentralasiatischer Kulturen im Umbruch vom 2. zum 1. Vorchristlichen Jahrtausend: Akten Des Internationalen Kolloquiums, Berlin, 23-26. November 1999 (ss. 383-410). Habelt.

Baştürk, E. (2010). Asur Devletinin Yukarı Dicle Vadisi Yayılımı ve Politik Uygulamaları. D. B. Erciyas (Ed.) Güneydoğu Anadolu Araştırmaları Sempozyumu (ss. 139-149). Ege Yayınları.

Baydur, N. (1970). Kültepe (Kanȩ̧) ve Kayseri Tarihi Üzerine Araştırmalar. İstanbul Üniversitesi Edebiyat Fakültesi Yayınları.

Bayram, S. (1993). Kültepe Tabletlerinde Geçen Vergiler ve Özellikleri. Ankara Üniversitesi Dil ve Tarih-Coğrafya Fakültesi Dergisi, 36(1-2), 2-13.

Berndt-Ersöz, S. (2008). The Chronology and Historical Context of Midas. Historia, 57(1), 137.

Biber, H. (2018). Muş İli Arkeolojik Yüzey Araştırmaları, 2009-2014. Hiperlink Yayınları.

Bilgi, Ö. (1987). Köşkerbaba Höyük Kazısı, 1979. Aşă̆ı Fırat Projesi 1978-1979 Çalışmaları (ss. 217-249). Orta Doğu Teknik Üniversitesi Aşağı Fırat Projesi Yayınları. 
Binford, L. R. (1962). Archaeology as Anthropology. AmerAnt, 28(2), 217-225.

Bittel, K. ve Güterbock, H. G. (1933). Vorläufiger Berichte über die dritte Grabung in Boğazköy. MDOG, 72, 1-53.

Bossert, E. M. (2000). Die Keramik phrygischer Zeit von Boğazköy: Funde aus den Grabungskampagnen 1906, 1907, 1911, 1912, 1931-1937 und 1952-1960. Boğazköy-Hattusa XVIII. Philipp Von Zabern.

Bouthillier, C., Colantoni, C., Debruyne, S., Glatz, C., Hald, M. M., Heslop, D., Kozal, E., Miller, B., Popkin, P., Postgate, N., Steele, C. S. ve Stone, A. (2014). Further work at Kilise Tepe, 2007-2011: refining the Bronze to Iron Age transition. AnatSt, 64, 95 - 161. https:/ /doi:10.1017/S0066154614000076

Bron, F. ve Lemaire, A. (1989). Les inscriptions araméennes de Hazaël. RAssyr, 83(1), 35-44.

Bryce, T. (2012). The World of the Neo-Hittite Kingdoms, A Political and Military History. Oxford University Press.

Bunnens, G. (2000). Syria in the Iron Age: Problems of Definition. G. Bunnens (Ed.) Essays on Syria in the Iron Age (ss. 3-19). Peeters Publishers.

Burney, C. A. (1958). Early Anatolia in the Chalcohthic and Early Bronze Age. AnatSt, 8, 157209.

Chase-Dunn, C. ve Hall, T. D. (2000). Comparing World-Systems to Explain Social Evolution. R. Denemark, J. Friedman, B. Gills ve G. Modelski (Ed.) World System History (ss. 85-113). Oxford University Press.

Childe, V. G. (2006). Kendini Yaratan İnsan (Çev. F. Ofluoğlu). Varlık Yayınları.

Cogan, M. ve Tadmor, H. (1977). Gyges and Ashurbanipal: A Study in Literary Transmission. Orientalia, 46(1), 65-85.

Cohen, A. (1971). Cultural strategies in the organization of trading diasporas. C. Meillassoux (Ed.) L'évolution du commerce africain depuis le xixe siècle en Afrique de l'Ouest (ss. 266-281). Oxford University Press.

Cordani, V. (2016). The Development of the Hittite Iron Industry. A Reappraisal of the Written Sources. Die Welt Des Orients, 46(2), 162-176.

Crawford, H. E. W. (1973). Mesopotamia's Invisible Exports in the Third Millennium B.C. WorldArch, 5(2), 232-241.

Cripps, E. L. (2014). Review: Money and Prices in the Ur III Economy of Umma: Monetary Role of Silver and its Administration in Mesopotamia during the Ur III Period (c. 2112-2004 BCE). A Case Study of the Umma Province by Xiaoli Ouyang. WZKM, 104, 205-232.

Curtin, P. D. (1984). Trade Diasporas and Cross-Cultural Trade. Cross-Cultural Trade in World History (ss. 1-14). Cambridge University Press.

https://doi.org/10.1017/CBO9780511661198.002 
Cusick, J. G. (1998). Historiography of Acculturation: An Evaluation of Concepts and Their Application in Archeology. J. G. Cusick (Ed.) Studies in Culture Contact (ss. 122-138). Southern Illinois Univeristy Press.

de Jesus, P. ve Dardeniz, G. (2015). Archaeological and Geological Concepts on the Topic of Ancient Mining. Bulletin of the Mineral Research and Exploration, 151, 231-246.

Dercksen, J. (1996). The Old Assyrian Copper Trade in Anatolia. Peeters Publishers.

di Filippo, F. ve Mori, L. (2019). The Malatya plain in the network of interregional relations in the Late Bronze Age and Iron Ages. N. Durak ve M. Frangipane (Ed.) I. Uluslararast Arslantepe Arkeoloji Sempozyumu Bildirileri 4-6 Ekim 2018 Malatya (ss. 157-171). İnönü Üniversitesi Yayınları.

di Nocera, G. M. (2010). Metals and Metallurgy. Their Place in the Arslantepe Society Between the End of the 4th and Beginning of the 3rd Millennium BC. M. Frangipane (Ed.) Economic Centralisation in Formative States: The Archaeological Reconstruction of the Economic System in 4th Millennium Arslantepe (ss. 255-274). Sapienza Università di Roma

di Nocera, G. M. ve Palmieri, A. M. (2003). Dogu Anadolu Madenciliği. Arkeo Atlas, 2, 36-39.

Dinçol, A. M. (1994). Cultural and Political Contacts Between Asyyria and Urartu. Tel Aviv, 21, 6-21.

Dinçol, A. M. ve Kantman, S. (1968). Arkeolojide Yeni Kavramlar ve Metodolojik Araştırma Planlamasi. Belleten, 32, 331-353.

Dinçol, A. M. ve Kantman, S. (1969). Analitik Arkeoloji. İstanbul Üniversitesi Yayınları.

Dittmann, R., Huh, S., Mitschang, T., Müller, E., Röttger, U., Schmidt, C., ve Wicke, D. (2002). Şavi Höyük İlk Kazı Mevsimi Raporu, 2000. N. Tuna ve J. Velibeyoğlu (Ed.) Ilısu ve Kargamış Baraj Gölleri Altında Kalacak Arkeolojik ve Kültür Varlikların Kurtarma Projesi 2000 Yilı Çalışmaları (ss. 211-243). Orta Doğu Teknik Üniversitesi Taçdam Yayınları.

Doyle, M.W. (1986). Empires. Cornell University Press.

Dönmez, Ş. (2003). The Early Iron Age Problem in the Central Black Sea Region. B. Fischer, H. Genz, E. Jean ve K. Köroğlu (Eds.) Identifying Changes: The Transition from Bronze to Iron Ages in Anatolia and Its Neighbouring Regions, Proceedings of the International Workshop Istanbul, November 8-9, 2002 (ss. 213-228). Türk Eskiçağ Bilimleri Enstitüsü.

Drower, M. (1975). Ugarit. I. E. S. Edwards, C. J. Gadd, N. G. L. Hammond ve E. Sollberger (Eds.) Cambridge Ancient History Vol. II, Part 2, The Middle East and the Aegean Region, c.13801000 BC (ss. 130-148). Cambridge University Press.

Duru, R. (1979). Keban Projesi Değirmentepe Kazısı 1973. Orta Doğu Teknik Üniversitesi Keban Projesi Yayınları.

Duru, G. (2017). Geçmiş Geleceğin Çıkmazında. G. Duru, K. Eren ve E. Koparal (Ed.) Arkeolojik Şeyler (ss. 17-41). Ege Yayınları.

Duru, G. ve Özbaşaran, M. (2014). Mekan, Bağlam ve Arkeolog. Ö. Çevik ve B. Erdoğu (Eds.) Yerleşim Sistemleri ve Mekan Analizi (ss. 123-136). Ege Yayınları. 
Edens, C. (1992). Dynamics of Trade in the Ancient Mesopotamian "World System". American Anthropologist, 94(1), 118-139.

Efe, T. (2007). The theories of the 'Great Caravan Route' between Cilicia and Troy: the Early Bronze Age III Period in inland Western Anatolia. AnatSt, 57, 47-64.

Efe, T. ve Fidan, M. E. (2006). Pre-Middle Bronze Age metal objects from inland Western Anatolia: A typological and Chronological Evaluation. Anatolia Antiqua, 14, 15-43.

Ekholm, K. ve Friedman, J. (1982). "Capital" Imperialism and Exploitation in Ancient WorldSystems. Review (Fernand Braudel Center), 6(1), 87-109.

Emre, K. (1963). Pottery of Levels III and IV at the Kanis Karum. Anatolia, 8, 87-99.

Emre, K. (1995). Pilgrim-Flasks from Level I of the Karum of Kanish. Bulletin of the Middle Eastern Culture Center in Japan. 8. 173-200.

Erdem, A. Ü. (2012). Regional Variations in Iron Age Grooved Pottery in Eastern Anatolia. A. Çilingiroğlu ve A. Sagona (Eds.) Anatolian Iron Ages 7, The Proceedings of the Seventh Anatolian Iron Ages Colloquim Held at Edirne, 19-24 April 2010 (ss. 113-131). Peeters.

Ericson, J. E. ve Earle, T. K. (Ed.) Contexts for Prehistoric Exchange. Academic Press.

Erol, H. (2019). Old Assyrian Metal Trade, Its Volume and Interactions. Belleten, 83(298), 779806. https:// doi.org/10.37879/belleten.2019.779

Esin, U. (1971). Tepecik Kazısı 1969. Keban Projesi 1969 Çalışmaları (ss. 107-131). Orta Doğu Teknik Üniversitesi Keban Projesi Yayınları.

Esin, U. (1982). Tepecik Kazısı. Keban Projesi 1974-1975 Çalışmaları (ss. 71-119). Orta Doğu Teknik Üniversitesi Keban Projesi Yayınları.

Esin, U. (1986). Anadolu'ya ait Bazı Prehistorik Cüruf ve Filiz Analizleri. Anadolu Araştırmaları, 10, 143-160.

Esin, U. (1987). Değirmentepe Kazısı 1979. Aşă̆ı Fırat Projesi 1978-1979 Çalışmaları (ss. 89117). Orta Doğu Teknik Üniversitesi Aşağı Fırat Projesi Yayınları.

Esin, U., Arsebük, G. ve Özdoğan, M. (1987). Değirmentepe Kazısı, 1978. Aşağı Fırat Projesi 1978-1979 Çalışmaları (ss. 77-101). Orta Doğu Teknik Üniversitesi Aşağı Fırat Projesi Yayınlar1.

Esin, U. ve Arsebük, G. (1982). Tülintepe Kazısı, 1974. Keban Projesi 1974-1975 Çalışmaları (ss. 119-135). Orta Doğu Teknik Üniversitesi Keban Projesi Yayınları.

Esin, U. ve Harmankaya, S. (1986). Değirmentepe (Malatya-İmamoğlu Köyü) Kurtarma Kazısı. Kazı Sonuçları Toplantısı, 8(1). 95-137.

Ezer, S. (2008). Güneydoğu Anadolu Bölgesi Orta Tunç Çă̆ı Seramiği. [Yayımlanmamış Doktora Tezi], Ankara Üniversitesi.

Fales, F. M. (2008). On Pax Assyriaca in the Eighth-Seventh Centuries BCE and Its Implications. R. Cohen ve R. Westbrook (Eds.) Isaiah's Vision of Peace in Biblical and Modern 
International Relations (ss. 17-35). Palgrave Macmillan. https://doi.org/10.1007/978-1-13710442-7

Feldman, M., Master, D. M., Bianco, R. A., Burri, M., Stockhammer, P. W., Mittnik, A., Aja, A. J., Jeong, C. ve Krause, J. (2019). Ancient DNA sheds light on the genetic origins of early Iron Age Philistines. Science Advances, 5, 1-10. https://doi.org/10.1126/sciadv.aax0061

Frangipane, M. (1985). Developments of Metallurgy in the Near East. M. Liverani, A. Palmieri ve R. Peroni (Eds.) Studi di Paletnologia in Onore di Salvatore M. Puglisi (ss. 215-228). Universita Di Roma "La Sapienza”.

Frangipane, M. (1998). Arslantepe 1996: The Finding of an EBA-I Royal Tomb. Kazı Sonuçlar Toplantıst, 19(1), 291-309.

Frangipane, M. (2000). The Late Chalcolithic IEB I sequence at Arslantepe. Chronological and Cultural Remarks From A Frontier Site. C. Marro ve H. Hauptmann (Eds.) Chronologies des pays du Caucase et de l'Euphrate aux IVe-IIIe millénaires. From the Euphrates to the Caucasus: Chronologies for the 4th-3rd millennium B.C. vom Euphrat in den Kaukasus: Vergleichende Chronologie des 4. und 3. Jahrtausends v. Chr. Actes du Colloque d'Istanbul, 16-19 décembre 1998 (ss. 439-471). De Boccard.

Frangipane, M. (2001a). Centralization Process in Greater Mesopotamia: Uruk "Expansion" as the Climax of Systemic Interactions among Areas of the Greater Mesopotamian Region. M. S. Rothman (Ed.) Uruk Mesopotamia and its Neighbors: Cross-cultural Interactions in the Era of State Formation (ss. 307-348). School of American Research Press.

Frangipane, M. (2001b). The Transition between Two Opposing Forms of Power at Arslantepe (Malatya) at the Beginning of the 3rd Millennium B.C. TÜBA-AR, 4, 1-24. https://doi.org/10.22520/tubaar.2001.0001

Frangipane, M. (2009). Rise and collapse of the Late Uruk Centres in Upper Mesopotamia and Eastern Anatolia. Scienze Dell'Anticha, Storia Archaeologia Antropologia, 15, 25-41.

Frangipane, M. (2012). The Collapse of the 4th Millenium Centralised System at Arslantepe and the Far-Reaching Changes in 3rd Millenium Societies. M. Frangipane (Ed.) Origini Preistoria e Protostoria Delle Civilta Antiche XXXIV, Proceedings of the conference Fifty Years of Excavations and Researches at Arslantepe-Malatya (Turkey), Rome, December 5-7 2011 (ss. 237260). Gangemi Editore SpA.

Frangipane, M., Di Nocera, G. M. ve Siracusano, G. (2011). Zeytinlibahçe (Urfa) Höyük'teki Araştırmalar: 2002 Kazı Sezonu. N. Tuna ve O. Doonan (Eds.) Ilısu ve Kargamış Baraj Gölleri Altında Kalacak Arkeolojik ve Kültür Varlıkların Kurtarma Projesi 2001 Yılı Çalışmaları I (ss. 1-22). Orta Doğu Teknik Üniversitesi Taçdam Yayınları.

Frank, G. A. (1993). Bronze Age World System Cycles. CurrAnthr, 34(4), 383-429.

Fuchs, A. (2002). Reviewed work of Shigeo Yamada: The Construction of the Assyrian Empire: A Historical Study of the Inscriptions of Shalmaneser III (859-824 B.C.) Relating to His Campaigns in the West. JAOS, 122(3), 594-597.

Garelli, P. (1991). The Achievement of Tiglath-pileser III: Novelty or Continuity?. M. Cogan (Ed.) Studies in Assyrian History and Ancient Near Eastern Historiography Presented to Hayim Tadmor (ss. 46-51). The Magnes Press. https:/ / doi.org/10.1086/373859 
Gates, M.-H. (2001). Potmarks at Kinet Höyük and the Hittite Ceramic Industry. É. Jean, A. M. Dinçol ve S. Durugönül (Eds.) Kilikia: Mekanlar ve Yerel Güçler (M.Ö. 2. binyıl - M.S. 4. yüzyıl): Uluslararası Yuvarlak Masa Toplantısı Bildirileri İstanbul, 2-5 Kasım 1999 (ss. 137-157). De Boccard.

Genz, H. (2003). The Early Iron Age in Central Anatolia. B. Fischer, H. Genz, E. Jean ve K. Köroğlu (Eds.) Identifying Changes: The Transition from Bronze to Iron Ages in Anatolia and Its Neighbouring Regions, Proceedings of the International Workshop Istanbul, November 8-9, 2002 (ss. 179-191). Türk Eskiçă̆ Bilimleri Enstitüsü.

Genz, H. (2004). Büyükkaya I. Die Keramik der Eisenzeit: Funde aus den Grabungskampagnen 1993 bis 1998. Philip von Zabern.

Genz, H. (2005). Thoughts on the origin of the Iron Age pottery traditions in central Anatolia. A. Çilingiroğlu ve G. Darbshire (Eds.) Anatolian Iron Ages 5, Proceedings of the Fifth Anatolian Iron Ages Colloquium held at Van, 6-10 August 2001 (ss. 75-85). British Institute at Ankara.

Gerçek, N. İ. (2017). Approaches to Hittite Imperialism: A View from the »Old Kingdom« and "Early Empire« Periods (c. 1650-1350 BCE). A. Schachner (Ed.) Innovation versus Beharrung was macht den Unterschied des hethitischen Reichs im Anatolien des 2. Jahrtausends v. Chr.?, Byzas, 27 (ss. 21-39). Ege Yayınları.

Glassner, J. (1986). La chute d'Akkade: L'evenement et sa memoire. Vordern Orient.

Glatz, C. (2006). Contact, Interaction, Control-The Archaeology of Inter-Regional Relations in Late Bronze Age Anatolia. [Yayımlanmamış Doktora Tezi], University College London.

Glatz, C. (2009). Empire as network: Spheres of material interaction in Late Bronze Age Anatolia. JAnthArch, 28(2), 127-141.

Glatz, C. (2012). Bearing the Marks of Control? Reassessing Pot Marks in Late Bronze Age Anatolia. AJA, 116(1), 5-38. https://doi.org/10.3764/aja.116.1.0005

Glatz, C. (2013). A Comparative Investigation into the Responses to Hittite Imperialism by the Vassal State of Ugarit and the Kaska Peoples of Pontic Anatolia. G. E. Areshian (Ed.) Empires and Diversity, on the Crossroads of Archaeology, Anthropology and History (ss. 21-56). Cotsen Institute of Archaeology Press at UCLA. https:// doi.org/10.2307/j.ctvdjrqgq.7

Goldman, H. (1956). Excavations at Gözlü Kule, Tarsus. Vol. 2, The Neolithic through the Bronze Age. Princeton University Press.

Gunter, A. C. (1991). The Bronze Age. E. L. Kohler (Ed.) Gordion Excavations Final Reports. Vol III: The Bronze Age. University of Pennsylvania Press

Gunter, A. C. (2006). Issues in Hittite Ceramic Production: A View from the Western Frontier. D. P. Mielke, U. D. Schoop ve J. Seeher (Eds.), Strukturierung und Datierung der hethitischen Archäologie: Voraussetzungen-Probleme-Neue Ansätze. Internationaler Workshop Istanbul, 26-27 November 2004, Byzas, 4 (ss. 349-363). Ege Yayınları.

Gülçur, S. (2000). Norşuntepe: Die Chalkolithische Keramik (Elazığg/Ostanatolien). C. Marro ve H. Hauptmann (Eds.) Chronologies des pays du Caucase et de l'Euphrate aux IVe-IIIe millénaires. From the Euphrates to the Caucasus: Chronologies for the 4th-3rd millennium B.C. Vom 
Euphrat in den Kaukasus: Vergleichende Chronologie des 4. und 3. Jahrtausends v. Chr. Actes du Colloque d'Istanbul, 16-19 décembre 1998 (ss. 375-418). De Boccard.

Hall, T. D., Kardulias, N. P. ve Chase-Dunn, C. (2011). World-Systems Analysis and Archaeology: Continuing the Dialogue. Journal of Archaeological Research, 19, 233-279.

Hallo, W. W. (1960). From Qarqar to Carchemish: Assyria and Israel in the Light of New Discoveries. The Biblical Archaeologist, 23(2), 33-61. https:// doi.org/10.2307/3209160

Harmanşah, Ö. (2007). 'Source of the Tigris'. Event, place and performance in the Assyrian landscapes of the Early Iron Age. Archaeological Dialogues, 14(2), 179-204. https://doi.org/10.1017/S1380203807002334

Hauptmann, H. (1971). Norşuntepe Kazısı, 1969. Keban Projesi 1969 Çalışmalan (ss. 71-91). Orta Doğu Teknik Üniversitesi Keban Projesi Yayınları.

Hauptmann, H. (1974). Norşuntepe Kazıları, 1971. Keban Projesi 1971 Çalışmaları (ss. 71-103). Orta Doğu Teknik Üniversitesi Keban Projesi Yayınları.

Hauptmann, H. (1979). Kalkolitik Çağdan İlk Tunç Çağının Bitimine Kadar Norşuntepe'de Yerleşmenin Gelişimi. VIII. Türk Tarih Kongresi, I (ss. 55-65). Türk Tarih Kurumu Yayınları.

Hauptmann, H. (1982). Norşuntepe Kazıları. Keban Projesi 1974-1975 Çalışmaları (ss. 15-71). Orta Doğu Teknik Üniversitesi Keban Projesi Yayınları.

Hawkins, J. D. (1975). Hatti: the 1st millennium B.C. D. O. Edzard (Ed.) Reallexikon der Assyriologie und der Vorderasiatische Archaologie, 4 (ss. 152-159). De Gruyter.

Hawkins, J. D. (1982). The Neo-Hittite states in Syria and Anatolia. J. Boardman, I. E. S. Edwards, N. G. L. Hammond ve E. Sollberger (Eds.) The Cambridge Ancient History, Vol. 3, Part 1. The Prehistory of the Balkans, the Middle East and the Aegean World, Tenth to Eighth Centuries BC (ss. 372-442). Cambridge University Press.

https:/ / doi.org/10.1017/CHOL9780521224963.010

Hawkins, J. D. (1988). Kuzi-Tešub and the "Great Kings" of Karkamiš. AnatSt, 38, 99-108.

Hawkins, J. D. (1994). The End of the Bronze Age in Anatolia: New Light from Recent Discoveries. A. Çilingiroğlu ve D.H. French (Ed.) Anatolian Iron Ages 3: The Proceedings of the Third Anatolian Iron Ages Colloquium held at Van, 6-12 August 1990 (ss. 91-94). British Institute at Ankara.

Hawkins, J. D. (2000). Corpus of Hieroglyphic Luwian Inscriptions. De Gruyter. https://doi.org/10.1515/9783110804201

Hawkins, J. D. (2002). Die Erben des Grosreiches I: Die Geschichte der spathethitischen Kleinkonigreiche Anatoliens und Nordsyriens im Uberblick (ca. 1180-700 v. Chr.). W. Jacob (Ed.) Die Hethiter und ihr Reich: Das Volk der 1000 Gotter (56-59). Kunst-und Ausstellungshalle.

Helms, M. W. (1992). Long-Distance Contacts, Elite Aspirations, and the Age of Discovery in Cosmological Context. E. M. Schortman ve P. A. Urban (Ed.) Resources, Power, and Interregional Interaction. Interdisciplinary Contributions to Archaeology (ss. 157-174). Springer. 
Heltzer, M. (1977). The Metal Trade of Ugarit and the Problem of Transportation of Commercial Goods. Iraq, 39(2), 203-211. https:/ / doi.org/10.2307/4200067

Helwing, B. (1999). Cultural Interaction at Hassek Höyük, Turkey. New Evidence from Pottery Analysis. Paléorient, 25(1). 91-99. https://doi.org/10.3406/paleo.1999.991

Henrickson, R. C. (1993). Politics, Economics and Ceramic Continuity at Gordion in the Late Second and First Millennia BC. W. D. Kingery (Ed.) The Social and Cultural Contexts of New Ceramic Civilization Vol. VI (ss. 88-176). American Ceramic Society.

Henrickson, R. C. (1994). Continuity and Discontinity in the Ceramic Tradition of Gordion during the Iron Age. A. Çilingiroğlu ve D. H. French (Eds.) Anatolian Iron Ages 3: The Proceedings of the Third Anatolian Iron Ages Colloquium held at Van, 6-12 August 1990 (ss. 95130). British Institute at Ankara.

Henrickson, R. C. (1995). Hittite Pottery and Potters: The View from Late Bronze Age Gordion. Biblical Archaeologist, 58, 82-90.

Hodder, I. (1979). Economic and Social Stress and Material Culture Patterning. AmerAnt, $44(3), 446-454$.

Hodder, I. (1985). Postprocessual Archaeology. Advances in Archaeological Method and Theory, $8,1-26$.

Hodder, I. (2015). İnsan-Şey Dolanıklığı: Uzun Vadeli Bir Bakış (Çev. E. Koparal). G. Duru, K. Eren, E. Koparal (Eds.) Arkeolojik Şeyler. TAG Türkiye Toplantısı Bildirileri 2 (ss. 1-15). Ege Yayınlar1.

Hodder, I. (2018). Dolanıklık (Çev. B. C. Yılmazyiğit). Alfa Yayıncılık.

Ingman, T., Eisenmann, S., Skourtanioti, E., Akar, M., Ilgner, J., Ruscone, G. A. G., Roux, P. le, Shafiq, R., Neumann, G. U., Keller, M., Freund, C., Marzo, S., Lucas, M., Krause, J., Roberts, P., Yener, K. A., ve Stockhammer, P. W. (2021). Human mobility at Tell Atchana (Alalakh) during the 2nd millennium BC: Integration of isotopic and genomic evidence. PLoS ONE 16(6): e0241883. https:/ / doi.org/10.1371/journal.pone.0241883

Jaworski, W. (2008). Contents Modelling of Neo-sumerian Ur III Economic Text Corpus. D. Scott ve H. Uszkoreit (Ed.) Proceedings of the 22nd International Conference on Computational Linguistics (ss. 369-376). Association for Computational Linguistics.

Kalkan, E. (2015). Uruk Yayılım Kuramları: Tarihteki En Eski Koloniciler Barışçılar mı Savaşçılar mı? Kuramsal Bir Değerlendirme. Ege Yayınları.

Karg, N. (1999). Gre Dimse 1998: Başlangıç Raporu. J. Öztürk ve N. Tuna (Ed.) Ilısu ve Karkamış Baraj Gölleri Altında Kalacak Arkeolojik Kültür Varlıklarını Kurtarma Projesi 1998 Yılı Çalışmaları (ss. 237-296). Orta Doğu Teknik Üniversitesi Taçdam Yayınları.

Karg, N. (2001). Gre Dimse 1999, İlk Sonuçlar. N. Tuna, J. Öztürk ve J. Velibeyoğlu (Eds.) Ilısu ve Kargamış Baraj Gölleri Altında Kalacak Arkeolojik ve Kültür Varlıklarnı Kurtarma Projesi 1999 Yılı Çalışmalan (ss. 643-695). Orta Doğu Teknik Üniversitesi Taçdam Yayınları. 
Karg, N. (2002). 2000 Yılı Gre Dimse (Ilısu) Kazı Çalışmaları. N. Tuna ve J. Velibeyoğlu (Eds.) Ilısu ve Kargamış Baraj Gölleri Altında Kalacak Arkeolojik ve Kültür Varlıklarını Kurtarma Projesi 2000 Yılı Çalışmalan (ss. 699-737). Orta Doğu Teknik Üniversitesi Taçdam Yayınları.

Kealhofer, L., Grave, P., Marsh, B., Steadman, S., Gorny, R. ve G. Summers (2010). Patterns of Iron Age interaction in central Anatolia: Three sites in Yozgat province. AnatSt, 60, 71-92. https://doi:10.1017/S0066154600001022

Kertai, D. (2008/2009). The History of the Middle-Assyrian Empire. Talanta, 40-41, 25-51.

Kınal, F. (1991). Eski Anadolu Tarihi. Türk Tarih Kurumu Yayınları.

Kıymet, K. (2019). Hitit Metinlerinde Akad Çağı ile İlgili Kayıtlar. Türk Arkeoloji Dergisi, 38, 166.

Knappett, C. (2005). Thinking Through Material Culture: An Interdisciplinary Perspective. University of Pennsylvania Press.

Koehl, R. B. (2010). Mycenaean Pottery. K. A. Yener (Ed.) Tell Atchana, Ancient Alalakh Volume 1: The 2003-2004 Excavations Seasons (ss. 81-84). Koç University Press.

Koehl, R. B. (2020). Alalakh and the Aegean: Five Centuries of Shifting but Enduring Contacts. K. A. Yener ve T. Ingman (Eds.) Alalakh and Its Neighbours, Proceedings of the 15th Anniversary Symposium at the New Hatay Archaeology Museum, 10-12 June 2015 (ss. 201-225). Peeters.

Kohl, P. L. (1978). The Balance of Trade in Southwestern Asia in the Mid-Third Millennium B.C. CurrAnthr, 19(3), 463-475.

Kohl, P. L. (1987). The Use and Abuse of World Systems Theory: The Case of the Pristine West Asian State. Advances in Archaeological Method and Theory, 11, 1-35.

Konyar, E. (2006). Old Hittite Presence in the East of the Euphrates in the Light of the Stratigraphical Data form İmikuşağı (Elazığ). D. P. Mielke, U. D. Schoop ve J. Seeher (Eds.) Strukturierung und Datierung der hethitischen Archäologie: Voraussetzungen-Probleme-Neue Ansätze. Internationaler Workshop Istanbul, 26-27 November 2004, Byzas, 4 (ss. 333-348). Ege Yayınlar1.

Korbel, G. (1985). Die spätbronzezeitliche Keramik von Norşuntepe. Insitut fur Bauen und Planen.

Kozal, E. (2003). Red Lustrous Wheel-made Ware, Mycenaean and Cypriot Pottery in Anatolia. B. Fischer, H. Genz, E. Jean ve K. Köroğlu (Eds.) Identifying Changes: The Transition from Bronze to Iron Ages in Anatolia and Its Neighbouring Regions, Proceedings of the International Workshop Istanbul, November 8-9, 2002 (ss. 65-77). Türk Eskiçağ Bilimleri Enstitüsü.

Kozal, E. (2010). Cypriot Pottery. K. A. Yener (Ed.) Tell Atchana, Ancient Alalakh Volume 1: The 2003-2004 Excavations Seasons (ss. 67-80). Koç University Press.

Kozbe, G. ve Köroğlu, K. (2011a). Kavuşan Höyük 2002 Yılı Kazısı. N. Tuna ve O. Doonan (Eds.) Ilısu ve Kargamış Baraj Gölleri Altında Kalacak Arkeolojik ve Kültür Varlıklarını Kurtarma Projesi 2001 Yılı Çalışmaları, II (ss. 623-641). Orta Doğu Teknik Üniversitesi Taçdam Yayınları. 
Kozbe, G. ve Köroğlu, K. (2011b). Kavuşan Höyük 2002 Yılı Kazısı. N. Tuna ve O. Doonan (Eds.) Ilısu ve Kargamış Baraj Gölleri Altında Kalacak Arkeolojik ve Kültür Varlıklarını Kurtarma Projesi 2001 Yılı Çalışmaları, II (ss. 687-697). Orta Doğu Teknik Üniversitesi Taçdam Yayınları.

Köroğlu, K. (1998). Üçtepe I, Yeni Kazı ve Yüzey Bulguları Işığında Diyarbakır/Üçtepe ve Çevresinin Yeni Asur Dönemi Tarihi Coğrafyası. Türk Tarih Kurumu Yayınları.

Köroğlu, K. (2003). The Transition from Bronze Age to Iron Age in Eastern Anatolia. B. Fischer, H. Genz, E. Jean ve K. Köroğlu (Eds.) Identifying Changes: The Transition from Bronze to Iron Ages in Anatolia and Its Neighbouring Regions, Proceedings of the International Workshop Istanbul, November 8-9, 2002 (ss. 231-241). Türk Eskiçağ Bilimleri Enstitüsü.

Köroğlu, K. (2006). Eski Mezopotamya Tarihi: Başlangıcından Perslere Kadar. İletişim Yayınları.

Kristiansen, K. (2018). The Rise of Bronze Age Peripheries and the Expansion of International Trade 1950-1100 BC. K. Kristiansen, T. Lindkvist ve J. Myrdal (Eds.), Trade and Civilisation: Economic Networks and Cultural Ties, from Prehistory to the Early Modern Era (ss. 87-112). Cambridge Univeristy Press. https://doi.org/10.1017/9781108340946.005

Kulakoğlu, F. (2011). Kültepe-Kaneš: A Second Millennium B.C.E. Trading Center on the Central Plateau. S. Steadman ve G. McMahon (Eds.) The Oxford Handbook of Ancient Anatolia: (10,000-323 BCE) (ss. 1012-1030). Oxford University Publications.

https://doi.org/10.1093/oxfordhb/9780195376142.013.0047

Kulakoğlu, F. (2014). Kanesh afer the Assyrian Colony Period: Current Research at Kültepe and the Question of the End of the Bronze Age Settlement. L. Atıc1, F. Kulakoğlu, G. Barjamovic ve A. Fairbairn (Eds.) Current Research at Kültepe-Kanesh: An Interdisciplinary and Integrative Approach to Trade Networks, Internationalism, and Identity (ss. 85-94). Lockwood Press. https://doi.org/10.2307/j.ctvvnd58.8

Kulakoğlu, F. ve Öztürk, G. (2015). New evidence for international trade in Bronze Age central Anatolia: recently discovered bullae at Kültepe-Kanesh. Antiquity Project Gallery, 89(343). http://antiquity.ac.uk/projgall/kulakoglu343

Kunç, S., Eker, A., Kapur, S. ve Gündoğdu, N. (1983). Değirmentepe Cüruf Buluntuları Analizi. TÜBİTAK Arkeometri Ünitesi Bilimsel Toplantı Bildirileri IV, 133-139.

Kurt, M. (2010a). Tabal Ülkesi'nin Politik ve İdari Yapısı. Selçuk Üniversitesi Sosyal Bilimler Enstitüsü Dergisi, 23, 128-136.

Kurt, M. (2010b). II. Sargon Devri Kaynakları Işığında Güney Anadolu ve Toros Dağları Bölgesi. Tarih Araştırmalarn Dergisi, 29(48), 69-89.

Kuzuoğlu, R. (2010). MÖ. II. Binin İlk Çeyreğinde Anadolu'da Yaşanan İsyanlar ve İç Husursuzluklar. A. Süel (Ed.) VII. Hititoloji Kongresi Bildirileri I. Cilt, Çorum 25-31 Ağustos 2008 (ss. 479-488). T. C. Çorum Valiliğii.

Larsen, M. (1976). The Old Assyrian City-State and Its Colonies. Akademisk Vorlag.

Larsen, M. T. (1977). Partnerships in the Old Assyrian Trade. Iraq, 39(1), 119-145. https://doi.org/10.2307/4200057 
Larsen, M. T. (1987). Commercial Networks in the Ancient Near East. M. Rowlands, M. T. Larsen ve K. Kristiansen (Eds.) Centre and Periphery in the Ancient World (ss. 47-56). Cambridge University Press.

Lehmann, G. (2013). Aegean-style pottery in Syria and Lebanon during Iron Age I. A. Killebrew ve G. Lehmann (Eds.) The Philistines and Other "Sea Peoples" in Text and Archaeology (ss. 265-328). Society of Biblical Literature.

Lehmann, G. ve Sheva, B. (2007). Decorated Pottery Styles in the Northern Levant during the Early Iron Age and their Relationship with Cyprus and the Aegean. Ugarit Forschungen, 39, 487-550.

Lehner, J. W. ve Yener, K. A. (2014). Organization and Specialization of Early Mining and Metal Technologies in Anatolia. B. W. Roberts ve C. Thornton (Eds.), Archaeometallurgy in Global Perspective (ss. 529-557). Springer.

Lewy, J. (1958). Some Aspects of Commercial Life in Assyria and Asia Minor in the Nineteenth PreChristian Century. JAOS, 78(2), 89-101.

Lewy, H. (1964). Notes on the Political Organization of Asia Minor at the Time of the Old Assyrian Texts. Orientalia, 33, 181-198.

Liverani, M. (1988). The Growth of the Assyrian Empire in the Habur/Middle Euphrates Area: A New Paradigm. State Archives of Assyria / Bulletin 2, 81-98.

Liverani, M. (2012). Arslantepe in the Neo-Hittite Period. Origini, 34, 331-344.

Luckenbill, D. D. (1926). Ancient Records of Assyria and Babylonia, I. The University of Chiago Press.

Mac Sweeney, N. (2010). Hittites and Arzawans: A view form western Anatolia. AnatSt, 60, $7-24$.

Manning, S. W., Kromer, B., Kuniholm, P. ve Newton, M. W. (2001). Anatolian Tree Rings and a New Chronology for the East Mediterranean Bronze-Iron Ages. Science 294(5551), 2532-2535. https://doi.org/10.1126/science.1066112

Manuelli, F. (2009). Local Imitations and Foreign Imported Goods. Some problems and new questions on Red Lustrous Wheel-made Ware in the light of the new excavations of the Southern Step Trench at Yumuktepe/Mersin. Altorinatlische Forschungen, 36(2), 251-267. https://doi.org/10.1126/10.1524/aofo.2009.0016

Manuelli, F. (2010). Foreign influences and local tradition in the Iron Age pottery production from Arslantepe. Evidence from the new excavations of the Neo-Hittite levels. Mesopotamia, $45,71-85$.

Manuelli, F. (2013a). Arslantepe - Late Bronze Age: Hittite Influence and Local Traditions in an Eastern Anatolian Community. Dipartimento di Scienze dell'Antichitá.

Manuelli, F. (2013b). Pottery as an Indicator of Changing Interregional Relations in the Upper Euphrates Valley. The Case of the Late Bronze-Iron Age Assemblages from Arslantepe/Malatya. K. A. Yener (Ed.) Across the Border: Late Bronze Age-Iron Age Relations 
between Syria and Anatolia, Proceedings of a Symposium held at the Research Center of Anatolian Studies, Koç University, İstanbul, May 31-June 1, 2010 (ss. 373-379). Peeters.

Manuelli, F. (2016). What Remains when Contact Breaks Off? Survival of Knowledge and Techniques in the Material Culture of the Peripheral Regions of the Hittite Empire after Its Dissolution. E. Foietta, C. Ferrandi, E. Quirico, F. Giusto, M. Mortarini, J. Bruno ve L. Somma (Eds.) Cultural $\mathcal{E}$ Material Contacts in the Ancient Near East, Proceedings of the International Wrokshop 1-2 December 2014, Torino (ss. 26-36). Apice Libri.

Manuelli, F. (2019). From The Margin of The Hittite State to the Capital of the Kingdom of Melid: The Late Bronze and Iron Age Developments at Arslantepe. I. Uluslararast Arslantepe Arkeoloji Sempozyumu Bildirileri 4-6 Ekim 2018 Malatya (ss. 157-171). İnönü Üniversitesi Yayınları.

Manuelli F. ve Mori, L. (2016). "The King at the Gate" Monumental Fortifications and the Rise of Local Elites at Arslantepe at the and of the 2nd Millenium BCE. Origini, 39, 209-241.

Marx, K. (2011) Kapital, I. Cilt (Çev. M. Selik ve N. Satligan). Yordam Kitap.

Massa, M. ve Palmisano, A. (2018). Change and continuity in the long-distance exchange networks between western/central Anatolia, northern Levant and northern Mesopotamia, c.3200-1600 BCE. Journal of Antropological Archeology, 49, 65-87.

Massa, M. ve Şahoğlu, V. (2015). The 4.2 ka BP Climatic Event in West and Central Anatolia: Combining Palaeo-climatic Proxies and Archaeological Data. H. Meller, H. W. Arz, R. Jung, R. Risch (Ed.) 2200 BC - A climatic breakdown as a cause for the collapse of the old world? in Halle (ss. 61-78). Landesamt für Denkmalpflege und Archäologie Sachsen-Anhalt, Landesmuseum für Vorgeschichte.

Matessi, A. (2016). The Making of Hittite Imperial Landscapes: Territoriality and Balance of Power in South-Central Anatolia during the Late Bronze Age. Journal of Ancient Near Eastern History, 3(2), 117-162. https:// doi.org/10.1515/janeh-2017-0004

Matney, T., Roaf, M., MacGinnis, J. ve McDonald, H. (2004). Ziyaret Tepe Kazıları, 2001. N. Tuna, J. Greenhalgh ve J. Velibeyoğlu (Eds.) Ilısu ve Kargamış Baraj Gölleri Altında Kalacak Arkeolojik ve Kültür Varlıkların Kurtarma Projesi 2001 Yılı Çalışmaları (ss. 387-400). Orta Doğu Teknik Üniversitesi Taçdam Yayınları.

Matney, T., MacGinnis, J., McDonald, H., Roaf, M. ve Smith, M. (2011). Ziyaret Tepe Kazıları, 2002. N. Tuna ve O. Doonan (Ed.) Ilısu ve Kargamış Baraj Gölleri Altında Kalacak Arkeolojik ve Kültür Varlıklarını Kurtarma Projesi 2001 Yılı Çalışmaları, Cilt II (ss. 533-555). Orta Doğu Teknik Üniversitesi Taçdam Yayınları.

Matsumura, K. (2008). The Early Iron Age in Kaman-Kalehöyük: The Search for Its Roots. D. Bonatz, R. M. Czichon ve F. J. Kreppner (Eds.) Fundstellen Gessammelte Schriften zur Archaologie und Geschichte Altvorderasiens ad honorem Hartmut Kühne (ss. 41-50). Harrassowitz Verlag.

Maxwell-Hyslop, K. R. (1977). Sources of Sumerian Gold: The Ur Goldwork from the Brotherton Library, University of Leeds. A Preliminary Report. Iraq, 39(1), 83-86. https://doi.org/10.2307/4200053

McGuire, R. H. (1992). A Marxist Archaeology. Academic Press. 
McGuire, R. H. (1993). Archaeology and Marxism. Archaeological Method and Theory, 5, 101-157.

McGuire, R. H. (2008). Archaeology as a Political Action. University of California Press.

McMahon, A. (2020). Early Urbanism in Northern Mesopotamia. Journal of Archaeological Research, 28, 289-337.

Mellaart, J. ve Murray, N. (1995). Beycesultan Vol. III Part II, British Institute of Archaeology at Ankara.

Melville, S. C. (2010). Kings of Tabal: Politics, Competition, and Conflict in a Contested Periphery. S. Richardson (Ed.), Rebellions and Peripheries in the Mesopotamian World (ss. 87109). American Oriental Society.

Michel, C. (1991). Innaya dans les tablettes paléo-assyriennes. Recherche Sur Les Civilisations.

Michel, C. (2008). The Old Assyrian Trade in the light of Recent Kültepe Archives. Journal of the Canadian Society for Mesopotamian Studies, 71-82.

Michel, C. (2017). Economy, Society, and Daily Life in the Old Assyrian Period. E. Frahm (Ed.) A Companion to Assyria (ss. 80-108). Cornwell Publishing.

Mielke, D. P. (2007). Red Lustrous Wheelmade Ware from Hittite Contexts. I. Hein (Ed.) The Lustrous Wares of Late Bronze Age Cyprus and the Eastern Mediterranean (ss. 155-169). VÖAW.

Mielke, D. P. (2016). Produktion und Distribution im Rahmen der hethitischen Wirtschaftsorganisation. K. Piesker (Ed.), Wirtschaft als Machtbasis, Beiträge zur Rekonstruktion vor moderner Wirtschaftssysteme in Anatolien, Byzas, 22 (ss. 155-186). Ege Yayınları.

Mielke, D. P. (2017). From »Anatolian« to »Hittite«. The Development of Pottery in Central Anatolia in the 2 nd Millennium BC. A. Schachner (Ed.), Innovation versus Beharrung: Was macht den Unterschied des hethitischen Reichs im Anatolien des 2. Jahrtausends v. Chr.? Internationaler Workshop zu Ehren von Jürgen Seeher, Istanbul, 23-24. Mai 2014. Byzas, 23 (ss. 121-144). Ege Yayınları.

Morrison, K. D. (2009). Sources, Approaches, Definitions. S. E. Alcock, T. N. D'Altroy, K. D. Morrison ve C. M. Sinopoli (Eds.) Empires: Perspectives From Archaeology and History (ss. 1-9). Cambridge University Press.

Müller, U. (2005). Norşun Tepe and Lidar Höyük. Two examples for cultural change during the Early Iron Age. A. Çilingiroğlu ve G. Darbshire (Eds.) Anatolian Iron Ages 5, Proceedings of the Fifth Anatolian Iron Ages Colloquium held at Van, 6-10 August 2001 (ss. 107-114). British Institute at Ankara.

Müller-Karpe, A. (2002a). Die Keramik des mittleren und jüngeren hethitischen Reiches. Die Entwicklung der anatolischen Keramik - ihre Formen und Funktionen. W. Jacob (Ed.) Die Hethiter und ihr Reich: Das Volk der 1000 Gotter (256-263). Kunst-und Ausstellungshalle.

Müller-Karpe, M. (2002b). Zur Metallverwendung im Mesopotamien"des 4. und 3. Jahrtausends. Ü. Yalçın (Ed.) Anatolian Metal II (ss. 137- 148). Deutsches Bergbau Museum.

Neve, P. (1982). Büyükkale. Die Bauwerke. Grabungen 1954-1966. Boğazköy-Hattusa 12. Mann Verlag. 
Oates, J. (1993). Trade and Power in the Fifth and Fourth Millennia BC: New Evidence from Northern Mesopotamia. WorldArch, 24(3), 403-422.

Okun, M. L. (1989). An Example of the Process of Acculturation in the Early Roman Frontier. OJA, 8(1), 41-54.

Oppenheim, L. A. (1950). Babylonian and Assyrian Historical Texts. J. B. Prichard (Ed.) Ancient Near Eastern Texts Relating to the Old Testament. Princeton Univeristy Press.

Ökse, A. T. (1988). Mitteleisenzeitliche Keramik Zentral-Ostanatoliens mit dem Schwerpunkt Karakaya Stauseegebiet am Euphrat. Reimer-Verlag.

Ökse, A. T. (2015). Diyarbakır Kenti'nin En Eski Yerleşimi İçkale deki Amida Höyük. OLBA $23,59-110$.

Ökse, A. T. (2019). İşlev Analizlerinde Göstergelerin Yorumlanması: Gre Virike Örneği. Y. Ersoy, E. Koparal, G. Duru ve Z. Aktüre (Eds.) Arkeoloji ve Göstergebilim (ss. 71-89). Ege Yayınları.

Ökse, A. T. (2020). Yukarı Dicle Havzası-Ambar Çayı Vadisi Yerleşim Tarihi. OLBA 28, 1-34.

Ökse, A. T., Alp, A. O., Dağ, H. U., Engin, A., Görmüş, A. ve Mustafaoğlu, G. (2001). Salat Tepe 1999 Yüzey Araştırması. N. Tuna, J. Öztürk ve J. Velibeyoğlu (Eds.) Ilısu ve Kargamış Baraj Gölleri Altında Kalacak Arkeolojik ve Kültür Varlıkların Kurtarma Projesi 1999 Yılı Çalışmaları (ss. 593-643). Orta Doğu Teknik Üniversitesi Taçdam Yayınları.

Özbal, H. (1983). Tepecik ve Tülintepe Metal, Filiz ve Cüruf Analizleri Sonuçları. TÜBİTAK Arkeometri Ünitesi Bilimsel Toplantı Bildirileri III, 203-217.

Özbal, H. (1986). Değirmentepe Metal-Cüruf ve Filiz Analizleri. TÜBİTAK Arkeometri Ünitesi Bilimsel Toplantı Bildirileri VI, 101-113.

Özbal, R. (2011). The Chalcolithic of Southeast Anatolia. G. McMahon ve S. Steadman (Eds) The Oxford Handbook of Ancient Anatolia: (10,000-323 BCE) (ss. 174-204). Oxford University Press. https://doi.org/10.1093/oxfordhb/9780195376142.001.0001

Özbal, H., Adriaens, A. M. ve Earl, B. (1999). Hacinebi Metal Production and Exchange. Paléorient, 25(1), 57-65. https:// doi.org/10.3406/ paleo.1999.988

Özbal, H., Pehlivan, N. ve Earl, B. (2000). Durağan ve Bakır Çay Arsenik Cevherleşmelerinin Jeolojik, Mineralojik ve Kimyasal İncelenmesi. Arkeometri Sonuçları Toplantısı, 16, 29-40.

Özbilen, S. (2020). Arkeoloji; Geçmiş, Zaman ve Kuram. OANNES - Uluslararası Eskiçağ Tarihi Araştırmaları Dergisi, 2(1), 41-65.

Özdoğan, M. (1977). Aşağı Fırat Havzası 1977 Yüzey Araştırmaları. Orta Doğu Teknik Üniversitesi Aşağı Fırat Araştırmaları.

Özdoğan, M. (2012). 50 Soruda Arkeoloji. Bilim ve Gelecek Kitaplığı.

Özgüç, N. (2009). Samsat; Bir Başkent ve Kalenin Uzun Yaşamının 6000 Yıllık Döneminden Kesitler. Türk Tarih Kurumu Yayınları. 
Özgüç, T. (1950). Türk Tarih Kurumu Tarafından Yapılan Kültepe Kazısı Raporu 1948, Türk Tarih Kurumu Yayınları.

Özgüç, T. (1963). Early Anatolian Archaeology in the Light of Recent Research. Anatolia, 7, 142.

Özgüç, T. (1971). Demir Devrinde Kültepe ve Civarı. Türk Tarih Kurumu Yayınları.

Özgüç, T. (1973). Kululu Hakkında Yeni Gözlemler. Anadolu, 17, 1-18. https://doi.org/10.1501/andl_0000000149

Özgüç, T. (1986a). New Observations on the Relationship of Kültepe with Southeast Anatolia and North Syria during the Third Millennium B.C. J. V. Canby, E. Porada, B. S. Ridgway ve T. Stech (Eds.) Aspects of Change and Cultural Development. Essays in Honor of Machteld J. Mellink (ss. 31-47). The University of Wisconsin Press.

Özgüç, T. (1986b). Kültepe-Kanesh II: New Researches at the Center of the Assyrian Trading Colonies. Türk Tarih Kurumu Yayınları.

Özgüç, T. (1988). Kültepe and Anatolian Archaeology - Relating to the Assyrian Period. T. Mikasa (Ed.). Essays on Ancient Anatolia in the Second Millennium B.C., Bulletin of the Middle Eastern Culture Center in Japan III (ss. 1-21). Otto Harrassowitz.

Özgüç, T. (2005). Kültepe/Kaniš/Neša. Yapı Kredi Yayınları.

Özkan, S. (1993). Kummuh/Kumaha. Tarih İncelemeleri Dergisi, 8(1), 65-80.

Öztürk, G. (2019). Post-Akkadian and Ur III Features on Cylinder Seals from KültepeKanesh: An Iconographic and Stylistic Analysis. Adalya, 22, 45-67.

Palmieri, A. ve Sertok, K. (1994). Minerals in and Around Arslantepe. Arkeometri Sonuçlan Toplantısı, 19, 119-124

Palumbi, G. (2011). The Chalcolithic of Eastern Anatolia. G. McMahon ve S. Steadman (Eds.) The Oxford Handbook of Ancient Anatolia: (10,000-323 BCE) (ss. 205-226). Oxford University Press. https://doi.org/10.1093/oxfordhb/9780195376142.013.0009

Palumbi, G. (2012). Bridging the Frontiers. Pastoral Groups in the Upper Euphrates Region in the Early Third Millenium BCE. M. Frangipane (Ed.) Origini Preistoria e Protostoria delle Civilta Antiche XXXIV, Proceedings of the conference Fifty Years of Excavations and Researches at Arslantepe-Malatya (Turkey), Rome, December 5-7 2011 (ss. 237-260). Gangemi Editore SpA.

Pamir, H. (2013). Sabuniye: A Late Bronze-Iron Age Port Settlement on the Northeastern Mediterranean Coast. K. A. Yener (Ed.) Across the Border: Late Bronze Age-Iron Age Relations between Syria and Anatolia, Proceedings of a Symposium held at the Research Center of Anatolian Studies, Koç University, İstanbul, May 31-June 1, 2010 (ss. 173-195). Peeters.

Parker, B. J. (2001). The Mechanics of Empire; The Northern Frontier of Assyria as a Case Study in Imperial Dynamics. Neo-Assyrian Text Corpus Project.

Parker, B. J. (2002). At the Edge of Empire: Conceptualizing Assyria's Anatolian Frontier ca. 700 B.C. JAnthArch 21(3), 371-395. https:/ / doi.org/10.1016/S0278-4165(02)00005-3 
Parker, B. J. (2006). Toward an Understanding of Borderland Processes. AmerAnt, 71(1), 77100. https:// doi.org/10.2307/40035322

Parker, B. J. (2013). Kenan Tepe. Ilısu Barajı ve HES Projesi Arkeolojik Kazıları 2004-2008 Çalışmaları (ss. 210-245). T.C. Kültür ve Turizm Bakanlığı Yayınları.

Parker, B. J., Creekmore, A. ve Dodd, L. S. (2004). UTARP: Kenan Tepe'nin Kültürel Tarihi'nin Ön Sentezi. N. Tuna, J. Greenhalgh ve J. Velibeyoğlu (Eds.) Ilısu ve Kargamış Baraj Gölleri Altında Kalacak Arkeolojik ve Kültür Varlıkların Kurtarma Projesi 2001 Yılı Çalışmaları (ss. 547-602). Orta Doğu Teknik Üniversitesi Taçdam Yayınları.

Parker, B. J., Dodd, L. S., Creekmore, A., Paine, R., Moseman, E. ve Marley, M. (2011). Yukar1 Dicle Arkeolojik Araştırma Projesi (UTARP): 2002 Yılı Kenan Tepe Kazılarına Genal Bakış. N. Tuna ve O. Doonan (Eds.) Ilısu ve Karkamış Baraj Gölleri Altında Kalacak Arkeolojiik ve Kültür Varlıklarını Kurtarma Projesi 2002 Yılı Çalışmaları (ss. 703-756). Orta Doğu Teknik Üniversitesi Taçdam Yayınları.

Pearce, J. (2000). The Late Chalcolithic Sequence at Hacınebi Tepe, Turkey. C. Marro ve H. Hauptmann (Eds.) Chronologies des pays du Caucase et de l'Euphrate aux IVe-IIIe millénaires. From the Euphrates to the Caucasus: Chronologies for the 4th-3rd millennium B.C. vom Euphrat in den Kaukasus: Vergleichende Chronologie des 4. und 3. Jahrtausends v. Chr. Actes du Colloque d'Istanbul, 16-19 décembre 1998 (ss. 115-143). De Boccard.

Polacco, L. (1973). Topaklıdaki İtalyan Kazılarında: Tarih Öncesinden Bizans Dönemine. Anadolu, 17, 31-41.

Polanyi, K. (1957). Marketless Trading in Hammurabi's Time. K. Polanyi, C. M. Arensberg ve H. W. Pearson (Eds.) Trade and Market in the Early Empires: Economies in History and Theory (ss. 12-26). The Free Press.

Pollock, S. (1994). The Uruk World System: The Dynamics of Expansion of Early Mesopotamian Civilization. Science, 264(5164), 1481+.

Postgate, J. N. (1973). Assyrian Texts and Fragments. Iraq, 35(1), 13-36. https://doi.org/10.2307/4199949

Postgate, J. N. (1992). The Land of Assur and the Yoke of Assur. WorldArch, 23(3), 247-263.

Postgate, J. N. (2007). The Ceramics of Centralisation and Dissolution: A Case Study from Rough Cilicia. AnatSt, 57, 141-150.

Preucel, R. W. (2019). Arkeolojik Göstergebilim. Y. Ersoy, E. Koparal, G. Duru ve Z. Aktüre (Eds.) Arkeoloji ve Göstergebilim (ss. 3-21). Ege Yayınları.

Pucci, M. (2013). Chatal Höyük in the Amuq: Material Culture and Architecture during the Passage from the Late Bronze Age to the Early Iron Age. K. A. Yener (Ed.) Across the Border: Late Bronze-Iron Age Relations Between Syria and Anatolia, Proceedings of a Symposium held at the Research Center of Anatolian Studies, Koç University, Istanbul May 31-June 1, 2010 (ss. 89-113). Peetters.

Radner, K. (2018). Asur Kenti ve Asur Krallığı Tarihine Genel Bakış. K. Köroğlu ve S. F. Adalı (Eds.) Asurlular; Dicle'den Toroslar'a Tann Asur'un Krallığı (ss. 2-26). (Çev. G. BikeYazıcıŏglu, A. Keskin ve B. Nilgün-Öz). Yapı Kredi Yayınları. 
Renfrew, C. ve Bahn, P. (2017). Arkeoloji. (Çev. G. Ergin). Homer Yayınları.

Roaf, M. ve Schachner, A. (2005). The Bronze Age to Iron Age Transition in the upper Tigris Region: New Information from Ziyaret Tepe and Giricano. A. Çilingiroğlu ve G. Darbshire (Eds.) Anatolian Iron Ages 5, Proceedings of the Fifth Anatolian Iron Ages Colloquium held at Van, 6-10 August 2001 (ss. 115-123). British Institute at Ankara.

Roaf, M. (2003). Cultural Atlas of Mesopotamia and the Ancient Near East. Facts on File.

Sagona, A. G. ve Zimansky, P. E. (2009). Ancient Turkey. Routledge.

Sağlamtimur, H. (2013). Siirt-Türbe Höyük. Ilısu ve HES Projesi Arkeolojik Kazılar 2004-2008 Çalışmaları (ss. 135-163). T.C. Kültür ve Turizm Bakanlığı Yayınları.

Sams, G. K. (1994). The Gordion Excavations 1950-1973: Final Reports IV. The Early Phrygian Pottery. University of Pennsylvania Press.

San, O. (2000). Bazı Bulgular Işığında Anadoluda Kimmer ve İskit Varlı̆̆ı Üzerine Gözlemler. Belleten, 64(239), 1-26.

Schachner, A. (2004). 2001 Yılı Giricano Kazıları. N. Tuna, J. Greenhalgh ve J. Velibeyoğlu (Eds.) Ilısu ve Kargamış Baraj Gölleri Altında Kalacak Arkeolojik ve Kültür Varlıklarını Kurtarma Projesi 2001 Yılı Çalışmaları (ss. 505-533). Orta Doğu Teknik Üniversitesi Taçdam Yayınları.

Schachner, A. (2009). Das 16. Jahrhundert v. Chr.: Eine Zeitenwende im hethitischen Zentralanatolien. IstMitt, 59, 9-34.

Schneider, J. (1977). Was there a pre-capitalist world-system?. Peasant Studies, 6, 20-29.

Schoop, U. D. (2006). Dating the Hittites with Statistics: Ten Pottery Assemblages from Boğazköy-Hattusa. D. P. Mielke, U.-D. Schoop ve J. Seeher (Eds.) Strukturierung und Datierung der hethitischen Archäologie: Voraussetzungen-Probleme-Neue Ansätze. Internationaler Workshop Istanbul, 26-27 November 2004, Byzas, 4 (ss. 215-239). Ege Yayınlar1.

Schortman, E. M. ve Urban, P. A. (1987). Modeling Interregional Interaction in Prehistory. Advances in Archaeological Method and Theory, 11, 37-95.

Schwartz, M. ve Hollander, D. (2008). Bulk stable carbon and deuterium isotope analyses of bitumen artifacts from Hacinebi Tepe, Turkey: reconstructing broad economic patterns of the Uruk expansion. JAS, 35, 3144-3158.

Schwartz, M. ve Hollander, D. (2016). The Uruk expansion as dynamic process: A reconstruction of Middle to Late Uruk exchange patterns from bulk stable isotope analyses of bitumen artifacts. JAS, 7, 884-899.

Seeher, J. (2005). Überlegungen zur Beziehung zwischen dem hethitischen Kernreich und der Westküste Anatoliens im 2. Jahrtausend v. Chr. B. Horejs, R. Jung, E. Kaiser ve B. Terzan (Eds.) Interpretationsraum Bronzezeit. Bernhard Hänsel von seinen Schülern gewidmet (ss. 33-44). R. Habelt.

Serdaroğlu, Ü. (1977). Aşağı Fırat Havzasında Araştırmalar, 1975. Orta Doğu Teknik Üniversitesi Aşağı Fırat Havzası Araştırmaları. 
Sertok, K., Kulakoğlu, F. ve Squadrone, F. F. (2011). Şaraga Höyük 2002 Yılı Kazıları. N. Tuna ve O. Doonan (Eds.) Ilısu ve Kargamış Baraj Gölleri Altında Kalacak Arkeolojik ve Kültür Varlıklarını Kurtarma Projesi 2001 Yilı Çalışmaları, I (ss. 215-230). Orta Doğu Teknik Üniversitesi Taçdam Yayınları.

Sevin, V. (1991). The Early Iron Age in the Elazığ Region and the Problem of the Mushkians. AnatSt, 41, 87-97. https://doi.org/10.2307/3642931

Sherratt, A. (1990). Gordon Childe: Paradigms and Patterns in Prehistory. Australian Archaeolgy, 30, 3-13.

Sherratt, S. (2013). The ceramic phenomenon of the 'Sea Peoples': An overview. A. E. Killebrew ve G. Lehmann (Eds.) The Philistines and Other "Sea Peoples" in Text and Archaeology (ss. 619-644). Society for Biblical Literature.

Sherratt, A. G. ve Sherratt, E. S. (1998). Small worlds: interaction and identity in the ancient Mediterranean. E. Cline ve D. Harris-Cline (Ed.) The Aegean and the Orient in the Second Millennium (ss. 329-343). Université de Liège.

Simon, Z. (2017a). Philologische und geographische Bemerkungen zu den Toponymen der KULULU-Bleistreifen. Colloquium Anatolicum, 16, 163-177.

Simon, Z. (2017b). The Northern Border of Tabal. A. Mouton (Ed.) Hittitology today: Studies on Hittite and Neo-Hittite Anatolia in Honor of Emmanuel Laroche's 100th Birthday: 5e Rencontres d'archéologie de l'IFEA, Istanbul 21-22 novembre 2014 (ss. 201-211). Institut français d'études anatoliennes. https:/ / doi:10.4000/books.ifeagd.3542.

Sinopoli, C. M. (1994). The Archaeology of Empires. Annual Review of Anthropology, 23, 159180.

Sir-Gavaz, Ö. (2012). M.Ö. 14. Yüzyılda Hitit Vassali Ugarit, Mısır ve Doğu Akdeniz. Arkeoloji ve Sanat, 140, 25-35.

Skourtanioti, E., Erdal, Y. S., Frangipane, M., Restelli, F. B., Yener, K., Pinnock, F., Matthiae, P. ve Özbal, R. (2020). Genomic History of Neolithic to Bronze Age Anatolia, Northern Levant, and Southern Caucasus. Cell, 181(5), 1158-1175.

https://doi.org/10.1016/j.cell.2020.04.044

Slane, D. A. (1987). Middle and Late Bronze Age Architecture and Pottery in Gözlü Kule, Tarsus: a New Analysis. [Yayımlanmamış Doktora Tezi], Bryn Mawr College.

Starr, I. (1990). Queries to the Sungod Divination and Politics in Sargonid Assyria. Helsinki University Press.

Stein, G. (1998). World System Theory and Alternative Modes of Interaction in the Archaeology of Culture Contact. J. G. Cusick (Ed.) Studies in Culture Contact (ss. 202-234). Southern Illinois University Press.

Stein, G. (1999a). Rethinking World-Systems: Power, Distance and Diasporas in the Dynamics of Interregional Interaction. P. N. Kardulias (Ed.) World-Systems Theory in Practice: Leadership, Production, and Exchange (ss. 153-179). Rowman \& Littlefield Publishers. 
Stein, G. (1999b). Rethinking World-Systems: Diasporas, Colonies, and Interaction in Uruk Mesopotamia. University of Arizona Press.

Stein, G. (2002). From passive periphery to active agents: Emerging perspectives in the archaeology of interregional interaction. American Anthropologist, 104, 903-916.

Stein, G. (2008). A Theoritical Model for Political Economy and Social Identity in the Old Assyrian Colonies of Anatolia. TÜBA-AR, 11(4), 25-40.

Stein, G., Bernbeck, R., Coursey, C., McMahon, A., Miller, N. F., Misır, A., Nicola, J., Pittman, H., Pollock S. ve Wright, H. (1996). Uruk Colonies and Anatolian Communities: An Interim Report on the 1992-1993 Excavations at Hacinebi, Turkey. AJA, 100(2), 205-260. https://doi.org/10.2307/506903

Steinkeller, P. (1991). The Administrative and Economic Organization of the Ur III State: The Core and the Periphery. M. Gibson ve R. D. Biggs (Eds.) The Organization of Power; Aspects of Bureaucracy in the Ancient Near East (ss. 15-35). The Oriental Institute of Chicago.

Stratford, E. (2014). "Make Them Pay": Charting the Social Topography of an Old Assyrian Caravan Cycle. JCS, 66, 11-38. https://doi.org/10.5615/jcunestud.66.2014.0011

Şahoğlu, V. (2005). The Anatolian Trade Network and The Izmir Region During the Early Bronze Age. OJA, 24(4), 339-361. https:/ / doi.org/10.1111/j.1468-0092.2005.00240.x

Şenyurt, S. Y. (2010). Ovaören-Göstesin Geç Hitit/Luwi Hiyeroglif Yazıtı. Ş. Dönmez (Ed.) Veysel Donbaz'a Sunulan Yazılar DUB.SAR E.DUB.BA.A (ss. 261-268). Ege Yayınları.

Şenyurt, S. Y., Akçay, A. ve Kamış, Y. (2014). Ovaören 2013 Yılı Kazı Çalışmaları. Kazı Sonuçları Toplantısı, 36(2), 101-120.

Şenyurt, S. Y., Akçay, A. ve Kara, S. (2019). Alişar-4 Seramik Geleneği İçerisinde Ovaören Demir Çağı Geyik Figürlü Seramikleri. Seleucia, 9, 205-245.

Şenyurt, S. Y. ve Akçay, A. (2018). Topada Yazıtına Farklı Bir Bakış: Geç Hitit Döneminde Orta Anadolu'da Güç Dengeleri. TÜBA-AR, 22, 95-117.

http://dx.doi.org/10.22520/tubaar.2018.22.006

Tansuğ, K. (1949). Kimmer'lerin Anadolu'ya Girişleri ve M.Ö. 7. Yüzyılda Asur Devletinin Anadolu ile Münasebetleri. Ankara Üniversitesi Dil ve Tarih-Coğrafya Fakültesi Dergisi, 7(4), 535-550.

Tekin, H. (2009). Hakemi Use 2008 Yılı Kazılarında Keşfedilen Geç Asur Dönemi Mezarları. Hacettepe Üniversitesi Edebiyat Fakültesi Dergisi, 26(2), 193-211.

Tekin, H. (2017). Tarihöncesinde Mezopotamya; Yeni Yaklaşımlar, Yeni Yorumlar ve Yeni Kronoloji. Bilgin Yayınları.

Tekinalp, M. ve Alp, A. O. (1999). Harabe Bezikan Höyük 1998 Araştırması. N. Tuna ve J. Öztürk (Eds.) Ilısu ve Karkamış Baraj Gölleri Altında Kalacak Arkeolojik Kültür Varlıkların Kurtarma Projesi: 1998 yılı çalışmaları (ss. 215-228). Orta Doğu Teknik Üniversitesi Taçdam Yayınlar1.

Tezcan, B. (1968). 1968 Göllüdağ Kazısı. Türk Arkeoloji Dergisi, 17(2), 211-235. 
Tezcan, B. (1992). 1969 Göllüdağ Kazısı Türk Arkeoloji Dergisi, 30, 1-30.

Toptaş, K. (2020). Asur Belgelerinde Kimmerler. Akademik Bakış, 14(27), 31-60.

Trigger, B. G. (1984). Childe and Soviet Archaeology. Australian Archaeology, 18, 1-16.

Trigger, B. G. (1993). Marxism in Contemporary Western Archaeology. Archaeological Method and Theory, 5, 159-200.

Trigger, B. G. (2008). A History of Archaeological Thought. Cambridge University Press. https://doi.org/10.1017/CBO9780511813016

Ünal, A. (2005). Hititler Devrinde Anadolu III. Arkeoloji Sanat Yayınları.

Ünlü, E. (2015). Late Bronze-Early Iron Age painted pottery from the northeast Mediterranean settlements. C. Maner ve K. Kopanias (Eds.) NOSTOI. Indigenous Culture, Migration and Integration in the Aegean Islands and Western Anatolia during the Late Bronze Age and Early Iron Ages (ss. 517-529). Koç University Press.

Ünlü, E. (2017). Tell Tayinat Yerleşiminde Geç Tunç - Erken Demir Çağı Geçiş Dönemi Seramikleri Üzerinden Amik Ovası́nda Görülen Yerel Devamlllıklar ve Doğu Akdeniz Bağlantıları. OLBA, 25, 79-112.

van de Mieroop, M. (2000). Sargon of Agade and his Successors in Anatolia. SMEA, 42(1), 133-159.

Veenhof, K. (1972). Aspects of Old Assyrian Trade and Its Terminology. Brill.

Veenhof, K. R. (2010). Ancient Asur: The City, its Traders, and its Commercial Network. JESHO, 53(1/2), 39-82.

Venturi, F. (2010). Cultural breakdown or evolution? The impact of changes in 12th century BC Tell Afis. F. Venturi (Ed.) Societies in Transition. Evolutionary Processes in the Northern Levant between Late Bronze Age II and Early Iron Age. Papers Presented on the Occasion of the 20th Anniversary of the New Excavations in Tell Afis. Bologna, 15th November 2007 (ss. 1-27). Cooperativa Libraria Universitaria Editrice.

Voigt, M. M. (1994). Excavations at Gordion 1988-89: The Yassıhöyük Stratigraphic Sequence. A. Çilingiroğlu ve D. H. French (Eds.) Anatolian Iron Ages 3: The Proceedings of the Third Anatolian Iron Ages Colloquium held at Van, 6-12 August 1990 (ss. 265-294). British Institute at Ankara.

von der Osten, H. H. (1937). The Alishar Hüyük. Seasons of 1930-32, Part II. Oriental Institute Publications.

Wallerstein, I. (1974). The Modern World System I. Academic Press.

Wallerstein, I. (1979). The Capitalist World-Economy. Cambridge University Press.

Wallerstein, I. (1999). The West, Capitalism and The Modern World System. T. Brook ve G. Blue (Ed.) China and Historical Capitalism: Genealogies of Sinological Knowledge (ss. 10-57). Cambridge University Press.

Wallerstein, I. (2005). Dünya Sistemleri Analizi: Bir Giriş. (Çev. E. Abadoğlu). Aram Yayıncılık. 
Wallerstein, I. (2011). The Modern World-System I: Capitalist Agriculture and the Origins of the European World-Economy in the Sixteenth Century. University of California Press.

Weeden, M. (2010). Tuwati and Wasusarma: Imitating the Behaviour of Assyria. Iraq, 72, 3961. https:/ / doi.org/10.1017/S0021088900000589

Welton, L., Harrison, T., Batiuk, S., Ünlü, E., Janeway, B., Karakaya, D., Lipovitch, D., Lumb, D. ve Roames, J. (2019). Shifting Networks and Community Identity at Tell Tayinat in the Iron I (ca. 12th to Mid 10th Century B.C.E.). AJA, 123(2), 291-333. https://doi.org/10.3764/aja.123.2.0291

Whallon, R. (1979). An Archaeological Survey of the Keban Reservoir Area of East-Central Turkey. The University of Michican Press. https://doi.org/10.3998/mpub.11396138

Whallon, R. ve Kantman, S. (1969). Early Bronze Age Development in the Keban Reservoir, East-Central Turkey. CurrAnthr, 10(1), 128-133.

Willcox, G. H. (1974). A History of Deforestation as Indicated by Charcoal Analysis of Four Sites in Eastern Anatolia. AnatSt, 24, 117-133. https:/ / doi.org/10.2307/3642603

Winckler, H. (1889). Keilschrifttexte Sargons. Kessinger Publishing.

Yakar, J. (2002). East Anatolian Metallurgy in the Fourth and Third Millennia B.C.: Some Remarks. Ü. Yalçın (Ed.) Anatolian Metal II (ss. 15-26). Deutsches Bergbau Museum.

Yalçıklı, D. ve Tekinalp, V. M. (2004). Mezraa Höyük 2001 Yılı Kazıları. N. Tuna, J. Greenhalgh ve J. Velibeyoğlu (Eds.) Ilısu ve Kargamış Baraj Gölleri Altında Kalacak Arkeolojik ve Kültür Varlıklarını Kurtarma Projesi 2001 Yılı Çalışmaları (ss. 107-161). Orta Doğu Teknik Üniversitesi Taçdam Yayınları.

Yalçıklı, D. ve Tekinalp, V. M. (2011). Mezraa Höyük 2002 Yılı Kazıları. N. Tuna ve O. Doonan (Eds.) Ilısu ve Kargamış Baraj Gölleri Altında Kalacak Arkeolojik ve Kültür Varlıklarını Kurtarma Projesi 2001 Yılı Çalışmalan, I (ss. 119-142). Orta Doğu Teknik Üniversitesi Taçdam Yayınlar1.

Greenhalgh ve J. Velibeyoğlu (Eds.) Ilısu ve Kargamış Baraj Gölleri Altında Kalacak Arkeolojik ve Kültür Varlıklarını Kurtarma Projesi 2001 Yılı Çalışmaları (ss. 107-161). Orta Doğu Teknik Üniversitesi Taçdam Yayınları.

Yalçın, S. (2013). A Re-evaluation of the Late Bronze to Early Iron Age Transitional Period: Stratigraphic Sequence and Plain Ware of Tarsus-Gözlükule. K. A. Yener (Ed.) Across the Border: Late Bronze Age-Iron Age Relations between Syria and Anatolia, Proceedings of a Symposium held at the Research Center of Anatolian Studies, Koç University, İstanbul, May 31-June 1, 2010 (ss. 195-213). Peeters.

Yalçın, Ü., Hauptmann, H., Hauptmann, A. ve Pernicka, E. (1993). Norşuntepe'de Geç Kalkolitik Çağı Bakır Madenciliği Üzerine Arkeometallurjik Araştırmalar. Arkeometri Sonuçları Toplantısı, 8, 381-389.

Yalçın, Ü., Yalçın, H. G., Maas, A. ve İpek, Ö. (2015). Prähistorischer Kupferbergbau in Derekutuğun Derekutuğun Tarihöncesi Bakır İşletmeleri. Ü. Yalçın ve H.-D. Bienert (Eds.) Kültürlerin Köprüsü Anadolu Türk-Alman Eskiçă̆ Bilimlerinde Güncel Bilimsel Araştırmalar ve Yeni Bakış Açıları. Tagungsband des Internationalen Symposiums "Anatolien - Brücke der 
Kulturen" in Bonn vom 7. bis 9. Juli 2014 7-9 Temmuz 2014'te Bonn'da yapılan "Kültürlerin Köprüsü Anadolu" Konulu Uluslararası Sempozyum Kitabı (ss. 147-185). Deutschen BergbauMuseum.

Yener, K. A. (1995). Swords, Armor, and Figurines. The Biblical Archaeologist, 58(2), 101-107.

Yener, K. A. (Ed.) (2005). The Amuq Valley Regional Projects, Volume 1: Surveys in the Plain of Antioch and Orontes Delta, Turkey, 1995-2002. Oriental Intitüte Publications.

Yener, K. A. (2013). New Excavations at Alalakh: The 14th-12th Centuries BC. K. A. Yener (Ed.) Across the Border: Late Bronze Age-Iron Age Relations between Syria and Anatolia, Proceedings of a Symposium held at the Research Center of Anatolian Studies, Koç University, İstanbul, May 31-June 1, 2010 (ss. 11-37). Peeters.

Yener, K. A., Kulakoğlu, F., Yazgan, E., Kontani, R., Hayakawa, Y. C., Lehner, J. W., Dardeniz, G., Öztürk, G., Johnson, M., Kaptan, E. ve Hacar, A. (2015). New Tin Mines and Production Sites Near Kültepe in Turkey: A Third-Millennium BC Highland Production Model. Antiquity, 89(345), 596-612. https://doi.org/10.15184/aqy.2015.30

Yener, K. A. ve Vandiver, B. P. (1993). Reply to J. D. Muhly, 'Early Bronze Age Tin and the Taurus. AJA, 97(2), 255-264. https://doi.org/10.2307/505659

Yıldırım, T. (2006). An Early Bronze Age Cemetery at Resuloğlu, Near Uğurludağ, Çorum. A Preliminary Report of the Archaeological Work Carried Out Between Years 2003-2005. Anatolia Antiqua, 14, 1-14. https:// doi.org/10.3406/anata.2006.1061

Yıldırım, T. (2010). Resuloğlu Kazısı ve Anadolu Arkeolojisi'ne Katkıları. Çorum Kazı ve Araştırmalar Sempozyumu (ss. 11-28). T.C. Çorum Valiliği.

Yllmaz, M. A. (2012). Contributions to the Early Iron Age Problem in the Central Black Sea Region in Light of Vezirköprü/Oymaağaç Höyük Ceramics. TÜBA-AR, 15, 69-78.

Yılmaz, D. (2019). Erken Tunç Çağı' nda Anadolu'da Ticaret. O. Dumankaya (Ed.) Çă̆lar Boyunca Üretim ve Ticaret: Prehistorya'dan Bizans Dönemine (ss. 193-212). Bilgin Kültür Sanat.

Yiğit, T. (2000). Tabal. Ankara Üniversitesi Dil ve Tarih-Coğrafya Fakültesi Dergisi, 40(3-4), 177189.

Young, R. S. (1955). Gordion: Preliminary Report 1953. AJA, 59, 1-18. https://doi.org/10.2307/500929

\section{Elektronik Kaynaklar}

http:/ / oracc.org/ saao/P224485/. (Erişim Tarihi: 23.10.2020)

http://oracc.museum.upenn.edu/rinap/qpn-x-people\#Q006482.164， SargonＩI 001, Q006482, 194b, 198b. (Erişim Tarihi: 18.11.2020)

https://www.ucl.ac.uk/sargon/essentials/kings/sargonii/ (Erişim Tarihi: 28.09.2020)

http:/ / oracc.org/saao/P336799/ (Erişim Tarihi: 16.11.2020)

http:/ /oracc.org/rinap/Q003428/(Erişim Tarihi: 16.11.2020) 